\title{
ARTICLES
}

\section{WHILE EFFUSIVE, "CONCLUSORY” IS STILL QUITE ElUSIVE: THE STORY OF A WORD, IQBAL, AND A PERPLEXING LEXICAL INQUIRY OF SUPREME IMPORTANCE}

\author{
Donald J. Kochan $^{*}$
}

\begin{abstract}
This article is a story about the word "conclusory." The word is effusive in legal discourse, yet it has been largely elusive to the editors and drafters of dictionaries. Few dictionaries include the word "conclusory," and those that do have only recently adopted it. The small number of available dictionary definitions that do exist seem to fail to capture the word's usage in the legal world. This article explores this definitional perplexity. As the word "conclusory" has taken center stage in the procedural plays of civil litigation with the help of the 2009 U.S. Supreme Court decision in Ashcroft v. Iqbal, the need to attach coherent meaning to the word increasingly prevails upon the legal profession.
\end{abstract}

This article presents original research and data on the historical use of the word and its lexicographical coverage. It concludes that the inclusion of "conclusory" and its proper definition are long overdue and should be demanded of dictionaries, both legal and general. Lawyers need the word and are using it despite suboptimal inclusion or support for its use in reference books. As lawyers will

\footnotetext{
* Professor of Law, Chapman University School of Law. J.D., Cornell Law School, 1998. I thank Isa Lang and Ashley Spencer of Chapman University School of Law's Rinker Law Library for research assistance in acquiring obscure editions of dictionaries, and student Jessica Travis for valuable research assistance on Appendix E. I especially thank Jennifer L. Spinella for her comments on this article and her indispensible support.
} 
U N I V E R S I T Y O F P I T T S B U R G H L A W R E V I E W

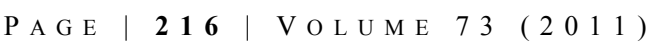

remain increasingly entangled in the word's meaning after Iqbal, an understanding of the word's story is critical as its meaning is explored and developed in case law, especially in the immediate nascent post-Iqbal world.

Given the difficulties of definition, the "conclusory" standard in Iqbal might turn out to be nothing more than - in homage to Justice Stewart's famous wordsan "I know it when I see it" standard. There is a sense in Iqbal that conclusory statements are like procedural pornography so profane and lacking in quality that they are not entitled to the protection of otherwise liberal pleading standards. This article concludes with the hope that some guidance can be found to navigate through civil procedure after Iqbal by directing our search for meaning to the process of analogy and contextual comparisons with other past usages of the term "conclusory" to apply to particular cases subject to Iqbal. 
Wh i L E EF F I I E, “CONCLUSORY” IS S T I L L E L U S IVE

\begin{tabular}{l|ll} 
P A G E & 217
\end{tabular}

\section{INTRODUCTION}

The meaning of the word "conclusory" seems, really, quite elusory. "Conclusory" is a widespread, common, and effusive word in the modern legal lexicon. ${ }^{1}$ Yet you would not necessarily know that by looking through many dictionaries. "Conclusory" has been a latecomer to the pages of most dictionaries. Even today, not all dictionaries include the word "conclusory," and those that do have only recently adopted it. The few available dictionary definitions seem to fail to capture the word's usage in the legal world. Yet the word "conclusory" has taken center stage in the procedural plays of civil litigation with the help of the 2009 U.S. Supreme Court decision in Ashcroft v. Iqbal. ${ }^{2}$ This article explores this definitional perplexity.

Judges, practitioners, legal scholars, and commentators are befuddled by, and struggling on multiple levels with, what to do about Iqbal and its jurisprudential sibling Bell Atlantic Corp. v. Twombly. ${ }^{3}$ As one of its major rules, Iqbal admonishes that " $[\mathrm{t}] \mathrm{hreadbare}$ recitals of the elements of a cause of action, supported by mere conclusory statements, do not suffice" to satisfy the pleading standards in Rule 8 of the Federal Rules of Civil Procedure and to survive a motion to dismiss under Rule 12(b)(6) for failure to state a claim upon which relief may be granted. ${ }^{4}$

Words are the tools in the lawyer's work belt and their use our occupation. ${ }^{5}$ The craft suffers if we look at a tool and remain confused how to use it or cannot understand its operation by others. The story of the word "conclusory" and its lexicographical struggle can help us better understand the confusion it has created

\footnotetext{
${ }^{1}$ See infra Part I.

${ }^{2}$ Ashcroft v. Iqbal, 556 U.S. 662 (2009).

${ }^{3}$ Bell Atl. Corp. v. Twombly, 550 U.S. 544 (2009).

${ }^{4}$ Iqbal, 556 U.S. at 678 (emphasis added).

${ }^{5}$ J. Allen Smith, Of Dictionaries, the "Bon Mot," and the "Mot Juste," 6 CARdozo Stud. L. \& Literature 123, 126 (1994) (quoting Charles Alan Wright, Book Review, Townes Hall Notes, Spring 1988, at 5 ("The only tool of the lawyer is words .... Whether we are trying a case, writing a brief, drafting a contract, or negotiating with an adversary, words are the only things we have to work with.")).
} 
U N I V E R S I T Y O F P I T T S B U R G H L A W R E V I E W

PAGE

in the law. ${ }^{6}$ Only then can we hope to move from confusion to some level of clarity.

We know a few general things about the word "conclusory" from our ordinary experiences with it. I posit that "conclusory" means, in its broadest sense, something approaching a very general idea of "a statement or inference without support" of one kind or another. Conclusory claims are sometimes called ipse dixit $^{7}$ - something with no support other than that it is said. As such, it is a modifier that oozes with the stain of poor quality, especially in the law. It is a pejorative term, evincing scorn for an argument like a scarlet letter, and is generally a label of unworthiness in an occupation that requires reasoned argument with support and persuasion. "Conclusory" is a wonderful word for describing that which is not good, whether it be in writing, speaking, judging, or pleading. We know that it is a tag to avoid and something we hope our work product is not called, but this article will explain that it is sometimes difficult to know exactly how to escape such negative branding of our work.

Dictionary definitions at best give us a general idea of what "conclusory" means but can hardly resolve the perplexity of how the word is used to filter acceptable from unacceptable pleadings. Black's Law Dictionary, for example, defines "conclusory" as "[e]xpressing a factual inference without stating the underlying facts on which the inference is based," providing the usage example of "because the plaintiff's allegations lacked any specific evidence they were merely conclusory." 8 Black's first included the word in 1999; the first six editions were silent on it despite attempts to be comprehensive. ${ }^{9}$ The current Black's definition gives us some idea of meaning. This article will show, however, that the Black's definition and others like it are neither the beginning nor the end of the inquiry surrounding the word, nor are dictionaries satisfactory enough for us to understand its meaning or importance in the context of Iqbal or other parts of the legal language and doctrine.

\footnotetext{
${ }^{6}$ Roy M. Mersky, The Evolution and Impact of Legal Dictionaries, 15 EXPERIENCE 32, 46 (2004) ("The dynamic relationship between legal lexicography and legal systems cannot be exaggerated. Scholars from any number of disciplines can benefit from a study of these materials.").

${ }^{7}$ Burrow v. Arce, 997 S.W.2d 229, 235 (Tex. 1999) (“[A] claim will not stand or fall on the mere ipse dixit of a credentialed witness.").

8 Black's Law Dictionary 329 (9th ed. 2009). See also Black's LaW Dictionary 308 (8th ed. 2004) (same definition); BLACK's LAW DictionARY 329 (7th ed. 1999) (same definition).

${ }^{9}$ Cf. Henry Campbell Black, Black's Law Dictionary, 5 HARV. L. REv. 155, 156 (1891) ("The aim was to include all words defined in any law dictionary, and this, we believe, has been done.").
} 
We know that "conclusory" is a quality filter. The filter's grade is what is rather unknown. In the end, we may decide that "conclusory" is just a word, and a definition of the word alone is not necessary or even all that helpful to understanding its meaning as used in Iqbal. Perhaps courts will never be able to "endeavor an encompassing definition of "conclusory" and will be left just deciding whether the label is apt in each case. ${ }^{10}$

If there is no clear discernible meaning of the word itself suitable to understanding its usage in Iqbal, it might be possible to use the doctrine of precedent to build a body of analogous case law from which argument and comparison can be made to guide courts in determining whether allegations are conclusory. More dangerously, however, the Iqbal "conclusory" standard may linger as a rule incapable of definition with any precision and subject to the caseby-case application in the courts - for good or bad, depending on whether one believes such an approach can be immune from the proclivities of individual judges and their possible biases on the merits of any claim.

In this latter sense, the conclusory standard in Iqbal might turn out to be nothing more than-in homage to Justice Stewart's famous words when discussing the judicial capacity to identify pornography that is not entitled to full First Amendment protection - an "I know it when I see it" standard. ${ }^{11}$ There is a sense in Iqbal that conclusory statements are like procedural pornography so profane and lacking in quality that they are not entitled to the protection of otherwise liberal pleading standards. In Iqbal, the majority and dissent both watched the same film but did not both see the obscenity in the allegations that warranted calling them conclusory. Yet courts across the country must screen pleadings and make this judgment every day. There is a serious concern that we are left only with judicial

\footnotetext{
${ }^{10}$ Senate of P.R. ex rel. Judiciary Comm. v. U.S. Dep't of Justice, 823 F.2d 574, 585 (D.C. Cir. 1987) ("We do not endeavor an encompassing definition of 'conclusory assertion'; for present purposes, it is enough to observe that where no factual support is provided for an essential element of the claimed privilege or shield, the label 'conclusory' is surely apt.").

${ }^{11}$ Jacobellis v. Ohio, 378 U.S. 184, 197 (1964) (Stewart, J., concurring). Justice Stewart explained:
}

I have reached the conclusion, which I think is confirmed at least by negative implication in the Court's decisions since Roth and Alberts, that under the First and Fourteenth Amendments criminal laws in this area are constitutionally limited to hard-core pornography. I shall not today attempt further to define the kinds of material I understand to be embraced within that shorthand description; and perhaps I could never succeed in intelligibly doing so. But I know it when I see it, and the motion picture involved in this case is not that.

Id. 
intuition. ${ }^{12}$ This article explores whether any critical guidance exists within the definition of the word or its usage by the courts.

Part I documents the usage of the word "conclusory" and the upward trend in its use throughout the past century. Part I also demonstrates a substantial history of usage of the word "conclusory" from which a reference set can be established to attempt to understand the meaning of the word as employed in the legal lexicon and beyond. Four original tables illustrate usage and trends, with much of the original raw data collection included in Appendices A-D at the conclusion of this article.

Part II summarizes the use of the word "conclusory" in the pleading standards established in the recent and monumentally important U.S. Supreme Court cases of Twombly and Iqbal. Part II also narrowly focuses on the limited portions of Iqbal and Twombly that deal with standards established around the word "conclusory," relying heavily on quotation from the cases to understand the word's use in context.

Part III then surveys the literature on Iqbal, highlighting scholarship that has attempted to give meaning to the word "conclusory" within the standard established in that case. This survey reinforces the conclusion that the Court has provided little guidance for the future application of the "conclusory" filter in examining the sufficiency of pleadings for purposes of motions to dismiss.

Part IV moves the inquiry into the word "conclusory" to dictionaries. As compiled and researched, Part IV provides the most comprehensive tale yet published of the struggle between the word and dictionaries. It begins with anecdotal stories related to the inclusion or non-inclusion of "conclusory" in dictionaries and proceeds to discuss the scholarly examination of the same, particularly providing an analysis of Bryan Garner's influential work on the word ${ }^{13}$

${ }^{12}$ Reinert has recently explained:

Iqbal extended Twombly to all civil actions and applied an even more rigorous standard to a civil rights action filed against high-level federal officials. The end result is a pleading standard that heightens attention to "conclusory" pleading, treats state of mind allegations in a manner at odds with prior precedent, and encourages lower courts to apply their own intuitions to decide whether a plaintiff's legal claims and allegations are sufficient to proceed to discovery.

Alexander A. Reinert, The Costs of Heightened Pleading, 86 IND. L.J. 119, 120-21 (2011).

${ }^{13}$ Garner discusses the word in ten published works, although each devotes just a page or a few pages to the topic: Bryan A. Garner, A Dictionary of MODERn AMERiCAN USAge 146 (1st ed. 1998) [hereinafter Garner, Modern American Usage]; Bryan A. Garner, A Dictionary of Modern Legal Usage 135 (1st ed. 1987) [hereinafter Garner, Modern Legal Usage]; Bryan A. GaRner, A Dictionary of Modern Legal Usage 191 (2d ed. 1995) [hereinafter Garner, Modern Legal 
along with original and never-before-published information on the history of dictionaries' treatments of the word. Part IV also critically examines the definition available in Black's Law Dictionary alongside other definitions provided from various sources authored by Bryan Garner where he also defined the word, establishing that dictionaries themselves do not provide a single controlling or even significantly guiding definition of "conclusory." Part IV concludes with a subsection reinforcing the conclusion that the dictionary definition is of little utility in understanding the meaning of "conclusory" in Iqbal and does not provide clear guidance to litigants or the courts in applying Iqbal's pleadings standards in that regard. Such a conclusion should not be surprising, I contend, in light of the inherent limitations in dictionaries themselves.

Given this lack of guidance on the meaning of the conclusory standard from the Court in Iqbal, available scholarship, or the dictionary definitions, Part V presents two primary conclusions: (1) the Iqbal "conclusory" prong has a low degree of predictability in its application and is largely subject to judicial interpretation of pleadings on a highly individualized, judge-specific, and case-bycase basis; and (2) one of the only methods available to operate within this high degree of uncertainty is to base one's understanding of the Iqbal test on the historical usages of the word (from the available usages charted in Part I) within past court decisions and elsewhere, analyzing whether an allegation is conclusory or nonconclusory through analogical reasoning to previous cases using the same terms in similar contexts. To assist in that endeavor, Appendix E provides a reference list of U.S. Supreme Court cases that have used the term "conclusory," with minor annotation to indicate some context of the usage. This article concludes by questioning whether the Iqbal test provides anything approaching a workable standard, even with a data set of potentially analogous uses of the term "conclusory" to draw from.

Usage 2]; Bryan A. Garner, A Dictionary of Modern Legal Usage 192 (3d ed. 2011) [hereinafter Garner, Modern Legal Usage 3]; Bryan A. Garner, Garner's Modern AMERICAN USAGE 174 (2d ed. 2003) [hereinafter GARNER, MOdern AMERICAN USAGE 2]; BRYAN A. GARNER, GARNER'S MODERN AMERICAN USAGE 178 (3d ed. 2009) [hereinafter GARNER, MODERN AMERICAN UsAge 3]; BRYAN A. GARNER, Novelties in Lawyer Talk, in GARNER ON LANGUAGE AND WRITING 327 (2009) [hereinafter Garner, Novelties]; Bryan A. Garner, The Elements of Legal Style 107 (1991) [hereinafter Garner, Elements]; Bryan A. Garner, The Missing Common-Law Words, in The State of The Language 239-49 (Christopher Ricks \& Leonard Michaels eds., 1990), reprinted in Garner on LANGuage AND Writing 342 (Bryan A. Garner ed., 2009) [hereinafter GARNER, Missing Words]; Bryan A. Garner, The RedboOK: A Manual on Legal Style 195 (1st ed. 2002) [hereinafter Garner, RedBoOK 1]; Bryan A. Garner, The RedBoOK: A MANUAl on Legal Style 226 (2d ed. 2006) [hereinafter GARNER, REDBOOK 2]. 
U N I V E R S I T Y O F P I T T S B U R G H L A W R E V I E W

PAGE

Given that the cases where a "conclusory" modifier has been used, as a whole, reflect the same type of interpretive and subjective division witnessed between the majority and dissent in the Iqbal decision itself, the first prong of Iqbal will likely remain unpredictable as currently stated. Some further clarification from the Court will be necessary before litigants can be confident in the sufficiency of their pleadings to withstand dismissal. Until there is some more concrete and understandable guidance on the first prong of Iqbal, the meaning of "conclusory" in that case will remain quite elusory to all those involved in civil litigation.

In slightly less than 45,000 words, this article will attempt to tell the history and story of one word: "conclusory." At the end, the reader will still not know what exactly that one word means. But therein, dear reader, lies the point of the exercise upon which we embark. It is a seat on the observation deck to the evolutionary spread of a word into our lexicon, a revelation about the fallibility of dictionaries, a recognition of the sometimes indeterminate use of language, a caution that a word's meaning is seldom revealed in isolation, a lesson on the importance of contextual analysis, a debate about the utility of flexibility in standards, and a charge in the face of unavoidable confusion to make the best use of skill and analogy to operate within the constraints of a new, judicially-demanded ante for entering the game of civil litigation.

\section{Tracing The USAGE OF THE WORD "CONCLUSORY"}

The word "conclusory" is not unknown in legal discourse, and its usage has seen dramatic increases in frequency in just the past several decades. Despite beliefs to the contrary, as a word, "conclusory" is nothing new. Because Iqbal has raised its visibility, however, it behooves the linguist, lexicographer, and legal interpreter alike to take a fresh, brief look at its historical usage.

A good place to start is a survey of the usage of the word "conclusory" in books across time. In 2010, Google Books introduced its Ngram Viewer to the public. ${ }^{14}$ The creators describe this new tool as "the first tool of its kind, capable of precisely and rapidly quantifying cultural trends based on massive quantities of data. It is a gateway to culturomics." 15 Google provides a browser that enables one

\footnotetext{
${ }^{14}$ Ngram Viewer, GoogLE BooKs, http://books.google.com/ngrams (last visited Feb. 17, 2012) (based on the model and database developed by Jean-Baptiste Michel et al., Quantitative Analysis of Culture Using Millions of Digitized Books, SCI., Jan. 14, 2011, at 176).

${ }^{15}$ Google Labs Ngram Viewer, Culturomics, http://www.culturomics.org/Resources/A-users-guideto-culturomics (last visited Feb. 17, 2012). See also Jean-Baptiste Michel et al., Quantitative Analysis of Culture Using Millions of Digitized Books, SCI., Jan. 14, 2011, at 176 (describing the tool and the database).
} 
"to examine the frequency of words ... or phrases ... in books over time."16 The database allows one to search "through over 5.2 million books: $\sim 4 \%$ of all books ever published." ${ }^{, 17}$ The creators see it as a tool with "profound consequences for the study of language, lexicography, and grammar."

Given that the tool is new, peer review is limited. Nonetheless, despite its inherent limitations and some recognized criticisms of its scientific value, ${ }^{19}$ a data analysis of the word "conclusory" and its possible substitutes or proxies produces some interesting and valuable raw data and optics using Google's database and technology.

${ }^{16}$ Michel et al., supra note 15.

${ }^{17}$ Id.

${ }^{18}$ Michel et al., supra note 15, at 178, Figure 2. See also id. at 177 ("Our results suggest that culturomic tools will aid lexicographers in at least two ways: (i) finding low-frequency words that they do not list; and (ii) providing accurate estimates of current frequency trends to reduce the lag between changes in the lexicon and changes in the dictionary.").

19 John Bohannon, Google Opens Books to New Cultural Studies, SCI., Dec. 17, 2010, at 1600 (describing the Ngram project and its initial critics). As the creators warn, "[b]asically, if you're going to use this corpus for scientific purposes, you'll need to do careful controls to make sure it can support your application. Like with any other piece of evidence about the human past, the challenge with culturomic trajectories lies in their interpretation." Google Labs Ngram Viewer, supra note 15. Suggestions for controls are available in the main paper supporting the application. See also Michel et al., supra note 15, at 181 ("Culturomic results are a new type of evidence in the humanities. As with fossils of ancient creatures, the challenge of culturomics lies in the interpretation of this evidence.") (giving a few example searches with interpretations). 
Table 1

GOOGLE BOOKS N-GRAM VIEWER

\section{Graph Conclusory From 1850 to 2008 From the Corpus of English with a Smoothing of 3}

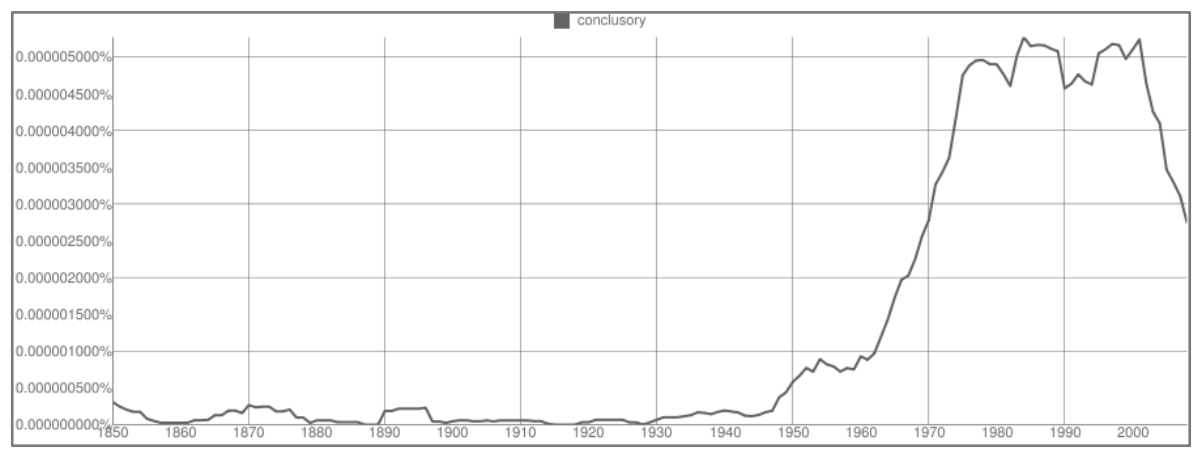

Source: GOOGLE BOOKS N-GRAM VIEWER, http://books.google.com/ngrams (last visited Feb. 27, 2012) (based on the model and database developed by JeanBaptiste Michel et al., Quantitative Analysis of Culture Using Millions of Digitized Books, 331 SCI., Jan. 14, 2011, at 176).

Table 1 shows trends from 1850 to 2008 for the unigram "conclusory." The yaxis shows what percentage of all the unigrams contained in Google's sample of books written in English have the word "conclusory." "Usage frequency is computed by dividing the number of instances of the n-gram in a given year by the total number of words in the corpus in that year."20 Smoothing allows for a consideration of the trends as a moving average and can be adjusted for any search. ${ }^{21}$ When one runs the search on Google, hyperlinks appear underneath the

${ }^{20}$ See Michel et al., supra note 15, at 181 . The Google Ngram data is "normalize[d] by the number of books published in each year." What's All This Do?, GOOGLE BOOKS, http://books.google.com/ngrams/ info (last visited Feb. 17, 2012).

${ }^{21}$ Google Books describes "smoothing” as follows:

Often trends become more apparent when data is viewed as a moving average. A smoothing of 1 means that the data shown for 1950 will be an average of the raw count for 1950 plus 1 value on either wide: ("count for 1949 " + "count for 1950 " + "count for 1951"), divided by 3. So a smoothing of 10 means that 21 values will be averaged: 10 on either side, plus the target value in the center of them. At the left and right edges of the graph, fewer values are averaged. With a smoothing of 3, the leftmost value (pretend it's the year 1950) will be calculated as ("count for 1950" + "count for 1951" + "count for 1952" + "count for 1953"), divided by 4. 
While EFfuSiVE, “CONCLUSORY” IS STIL L E L U IVE

graph, allowing one to browse through the books available that contributed to the data set. ${ }^{22}$

Although the unigram reveals "conclusory" appears in a very, very small percentage of the total books in Google's digitized collection, it certainly shows both a substantial frequency and a significant upward trend in its usage. This is, admittedly, only raw data. But the usage and trend are both apparent.

This data, of course, also does not control for the manner of use or context of use of the word. The compilation is overinclusive for this article's purposes because it includes uses of the word that may not be used in the way law has come to use the term. It should be noted that not all instances of "conclusory" were used in the same manner as the word is used among lawyers today. For example, the nineteenth century books available in Google used "conclusory" (1) as a noun or adjective for a concluding or an ending section in a book, speech, note, sermon, remarks, or the like; or (2) to distinguish between laws that were directory and those that were conclusory, which was used to mean essentially mandatory.

As one reviews the twentieth and twenty-first century books available in Google, one sees the waning use of "conclusory" in those regards and the emergence of "conclusory" as it is used today to indicate the lack of support. A general scan of the books within this search reveals that most of the modern references are based on the use of "conclusory" to mean something akin to statements without supporting facts, theories, or other bases. Its modern meaning undoubtedly accounts for most of the reported and increasing occurrences as one moves right on the unigram and sees the trend line sloping upward.

Moving the usage inquiry beyond general published books to court opinions reveals similar trends. To generally illustrate their point that "conclusory" is indeed used, two authors have made statements regarding the frequency of usage in court opinions. Block's analysis of the use of "conclusory" in the courts reports only 2860 federal and state case opinions ${ }^{23}$ where it was used, and Garner only states that it has been used in "more than 21,000 " cases. ${ }^{24}$ The material provided here confirms their general reports on usage, adds greater specificity in the numbers, provides up-to-date data beyond that available at the time of Garner and Block's

What's All This Do?, supra note 20.

${ }^{22} I d$. ("Below the graph, we show 'interesting' year ranges for your query terms. Clicking on those will submit your query directly to Google Books.”).

${ }^{23}$ Gertrude Block, 'Conclusory’ v. 'Conclusionary,' PA. LAW., Feb. 1999, at 53.

${ }^{24}$ Garner, Modern Legal Usage 3, supra note 13, at 192. 
publications, shows the trends in usage, and generally supports the proposition that dictionaries have shown a perplexing lag in recognition of the term "conclusory" given the significance of the quality and quantity of usage of the term across several decades.

Table 2

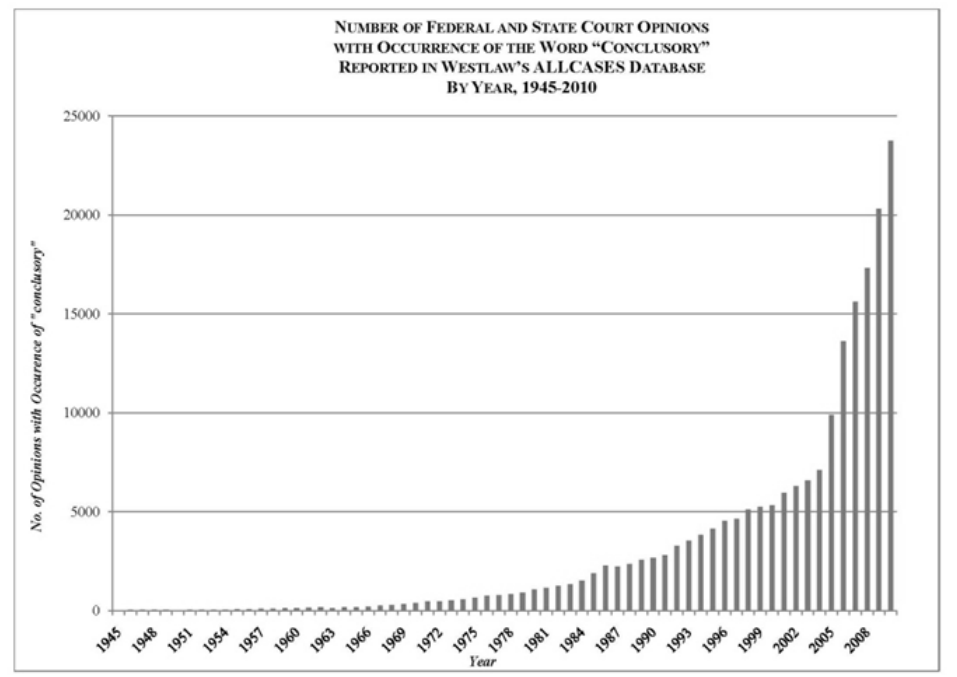

As Table 2 shows, a search in Westlaw's ALLCASES database finds the word "conclusory" has appeared in almost 200,000 cases, including more than 160,000 cases before the date of decision in Iqbal. ${ }^{25}$ The data also reveal a steady upward trend in the popularity (or perhaps recognition of the utility) of the term. Appendix $\mathrm{C}$ displays numeric data by year representing the number of State and Federal court opinions using the term "conclusory," and Appendix B displays the same data collected and aggregated every five years.

\footnotetext{
${ }^{25}$ Before May 18, 2009 (the date of the Iqbal opinion), the word "conclusory" appeared in 160,754 case opinion entries in Westlaw's ALLCASES database. After May 18, 2009, the word "conclusory" appeared in 73,654 case opinion entries in Westlaw's ALLCASES database through the end of August 2012. Search by author in Westlaw's ALLCASES database (Sept. 1, 2012).
} 
The first known use of "conclusory" in a written judicial opinion appears in the 1908 New York Supreme Court case of In re Canakos. ${ }^{26}$ In Canakos, the New York court reversed a decision by a lower court discharging a defendant who had been jailed for failure to pay a fine. The court determined that there was insufficient record evidence that the defendant was financially incapable of paying his fine, and it found that the court could not release the defendant simply due to the passage of time in jail. ${ }^{27}$ In so doing, the court explained that the defendant had "moved [and was granted] ... his discharge ... upon his own uncorroborated affidavit, uncorroborated even by a conclusory affidavit of his attorney, that he is unable to pay the amount of his fine. ${ }^{, 28}$ In finding the discharge improper, the court stated that "what is disclosed by the record and by the uncorroborated affidavit of the debtor was insufficient to justify his discharge under the Code." 29 It is not indisputably clear from the opinion in Canakos what type of meaning attached to the term "conclusory," but it is possible that the court was saying the attorney could not even provide an unsupported, minimal affidavit just affirming the statement of his client's financial condition, let alone provide a nonconclusory affidavit providing statements of fact supporting the client's statement of financial

${ }^{26}$ In re Canakos, 111 N.Y.S. 601, 602 (N.Y. App. Term 1908). The relevant heart of the short order read:

By virtue of an order dated February 18, 1908, the judgment debtor was fined the sum of $\$ 250$, to be paid within 15 days from the service of a copy of said order, or be committed for disobedience of a prior order to appear and make discovery on oath concerning his property. On February 28th, following, the debtor executed a chattel mortgage in the sum of $\$ 1,100$ to one Peter George, and then, declaring his inability to pay the fine imposed, was committed to the county jail. Thereafter he moved, even a second time, for his discharge under section 2286 of the Code of Civil Procedure, upon his own uncorroborated affidavit, uncorroborated even by a conclusory affidavit of his attorney, that he is unable to pay the amount of his fine, and was discharged; the court in a memorandum saying: "A judgment debtor who has languished 65 days in jail has been sufficiently punished for his failure to obey the mandate of the court." But "there is no inherent power in the court to release a defendant merely as a matter of grace or mercy" (Moore $\mathrm{v}$. McMahon, 20 Hun. 44, 45), and what is disclosed by the record and by the uncorroborated affidavit of the debtor was insufficient to justify his discharge under the Code (Matter of Steinert, 29 Hun, 301; Matter of Collins, 39 Misc. Rep. 753, 80 N.Y. Supp. 1119).

Id. (emphasis added).

${ }^{27} I d$.

${ }^{28} I d$. (emphasis added).

${ }^{29}$ Id. 
condition. That explanation is far more likely than that the court meant something akin to "conclusive," the older meaning of the term. Nonetheless, the usage is a bit ambiguous and the short opinion provides no further context to confidently accept this speculative interpretation of the reason for the word choice.

"Conclusory" was later used in a 1916 decision-the second discovered occurrence in a court opinion - but it was used for the purposes of meaning "final" or "all encompassing," in line with the older, rarer use of the term. ${ }^{30}$ That decision can be ignored for purposes of identifying the origin of the modern legal usage of the term in question.

Thus, the first use clearly in the modern parlance of "conclusory" was likely the 1923 New York Appellate Division case of Ringler v. Jetter. ${ }^{31}$ In previously published commentary on the word, Garner and Block date the word to Ringler, rather than to the 1908 decision in In re Canakos. ${ }^{32}$ The court in Ringler clearly used "conclusory" in the modern linguistic context and meaning when it discussed the insufficiency of "recitals ... of a conclusory sort" and ordered an amended complaint "wholly omitting these matters of conclusory import." ${ }^{, 33}$ Whether one

\footnotetext{
${ }^{30}$ Dishman v. Griffis, 73 So. 966, 969 (Ala. 1916) ("It is also true that a judgment may be conclusory of matters which might have been and ought to have been litigated, as well as of those actually litigated.").

${ }^{31}$ Ringler v. Jetter, 201 N.Y.S. 525, 525 (N.Y. App. Div. 1923).

${ }^{32}$ GARNER, Modern Legal Usage 3, supra note 13, at 192 ("Born in New York, the term [conclusory] has gained widespread currency since it first appeared in the 1920s.") (citing, inter alia, Ringler, 201 N.Y.S. at 525 ("[T] he motion [is] granted, to the extent of directing the service of an amended complaint, omitting paragraphs 16,17 , and 30 , and all conclusory matter of the nature pointed out herein.")); Block, supra note 23.
}

${ }^{33}$ Ringler, 201 N.Y.S. at 524-25. The full relevant paragraph is as follows:

Nor are the paragraphs which have some semblance of relation to the grievances of plaintiff properly worded, as befits good pleading. They contain numerous allegations of the pleader's conclusion of the betrayal of duty and gross neglect in office, malfeasance, misfeasance, misappropriation, conversion, destruction of credit by acts of the defendants, and averments that the recited conduct of the business constituted illegal and fraudulent acts of these directors, which recitals add nothing to the facts, except invective of a conclusory sort. These matters are so interpleaded in the complaint as to be impossible of separation from the context, and a proper remedy for their presence is to order the drafting and serving of an amended complaint, wholly omitting these matters of conclusory import, and confining the allegations to that plainness and conciseness of statement which sections 241 and 255 of the Civil Practice Act and rules 90 and 103 of the Rules of Civil Practice demand.

Id. (emphasis added). 
credits Canakos or Ringler as evidence of the first usage in a court opinion, it is clear that the courts began to accept the term many decades ago.

Narrowing the inquiry to the U.S. Supreme Court shows that the word "conclusory" has been used (through the end of 2011) in 281 opinions. ${ }^{34}$ In fact, "conclusory" has been used in at least one Supreme Court opinion almost every year since 1942. Table 3 displays this trend.

Table 3

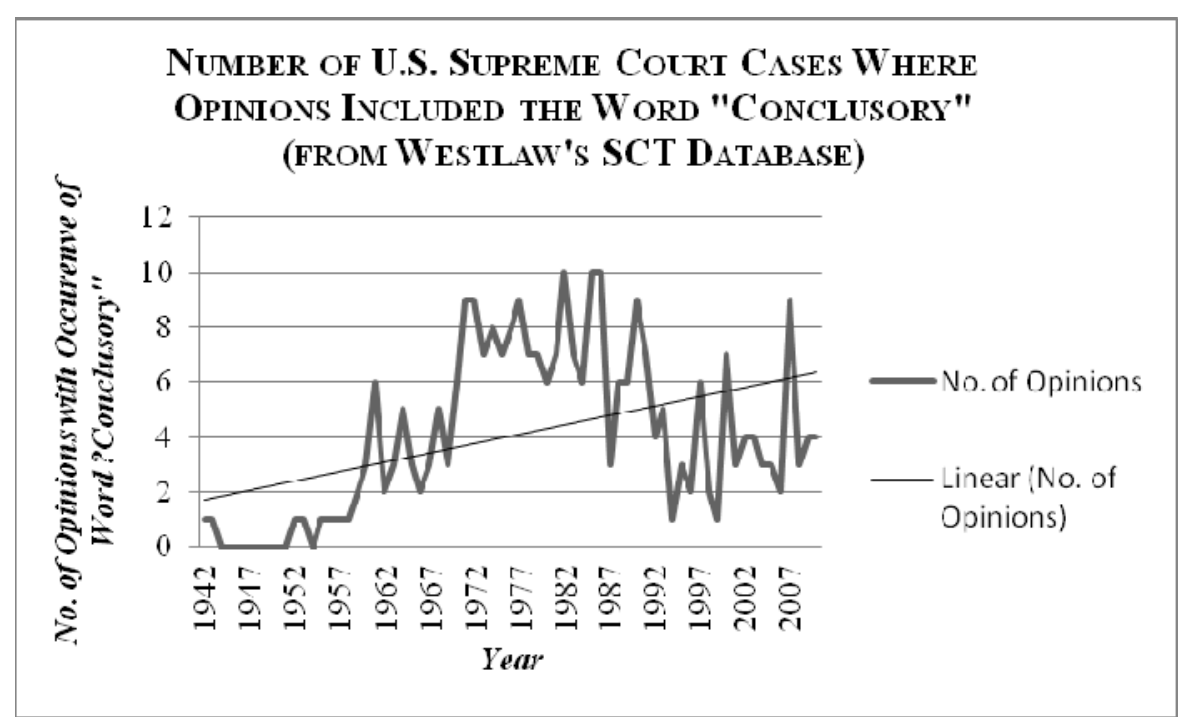

Appendix D displays numeric data representing the number of Supreme Court cases using the terms "conclusory." This data does not account for the quality of usage or the number of times "conclusory" is used in any particular case. To better grasp the quality and context, Appendix E lists the citation for each Supreme Court case that has used the word, the page where it is used, the Justice writing the opinion where it was used (where identifiable), and includes the modified or surrounding words to give some context to the usage of the word.

\footnotetext{
${ }^{34}$ Search by author in Westlaw's SCT database (Sept. 1, 2012). In addition to the opinions through 2011 and as of the final editing of this article, there is one U.S. Supreme Court opinion published in 2012 that used the word "conclusory," although it did so only in quoting the lower court. See PPL Montana v. Montana, 132 S. Ct. 1215, 1232 (2012) ("the Montana Supreme Court incorrectly stated the sole evidence for nonnavigability "consists of conclusory statements ... without any specific factual support."').
} 
The first occurrence of "conclusory" in a Supreme Court opinion was in United States v. Wayne Pump Co. in 1942, although the Court was only quoting a party's words in its background section from a list of the defendant's demurrers, without any incorporation of the word into the rest of its opinion. ${ }^{35}$ In the 1943 case of Schneiderman v. United States, the Supreme Court used "conclusory" to modify the word "findings" when it described findings issued by the district court that "did not specify evidence." "36 Usage in Schneiderman, therefore, seems to equate with the modern usage of "conclusory" as broadly meaning without evidence or supporting claims, and that case may have claim to be the first substantive use of the word in a Supreme Court opinion. Still, Zorach v. Clauson, in 1952, came much closer to an original use of the word by the pen of a Supreme Court Justice. In Zorach, the majority looked favorably on the New York Court of Appeals' use of the word "conclusory" to describe an insufficient "allegation" and incorporated the lower court's words into its own prose. ${ }^{37}$ The dissent also incorporated a quote from the New York Court of Appeals using "conclusory" in relation to allegations that the lower court dismissed. ${ }^{38}$ Some may argue that this is the first usage by the Supreme Court in the modern context. In 1953, Dalehite v. United States, like Schneiderman, used the word "conclusory" to clarify the Court's standard of review and to describe the types of findings by a lower court that it found not fully controlling on the Court's interpretation. ${ }^{39}$ In the 1955 case of Williams v. State of

${ }^{35}$ United States v. Wayne Pump Co., 317 U.S. 200, 208 n.3 (1942) (quoting district court's use of phrase "conclusory in character").

${ }^{36}$ Schneiderman v. United States, 320 U.S. 118, 153 n.40 (1943) ("Since the district court did not specify upon what evidence its conclusory findings rested, it is well to mention the remaining documents published.").

${ }^{37}$ Zorach v. Clauson, 343 U.S. 306, 311 n.7 (1952). The Court explained:

The only allegation in the complaint that bears on the issue is that the operation of the program "has resulted and inevitably results in the exercise of pressure and coercion upon parents and children to secure attendance by the children for religious instruction." But this charge does not even implicate the school authorities. The New York Court of Appeals was therefore generous in labeling it a "conclusory" allegation .... Since the allegation did not implicate the school authorities in the use of coercion, there is no basis for holding that the New York Court of Appeals under the guise of local practice defeated a federal right in the manner condemned by Brown $v$. Western R. Co. of Alabama, 338 U.S. 294 [(1949)] . . and related cases.

Id.

${ }^{38}$ Id. at 322 n.1 (1952) (Frankfurter, J., dissenting) ("Issues that raise federal claims cannot be foreclosed by the State court treating the allegations as 'conclusory in character."').

${ }^{39}$ Dalehite v. United States, 346 U.S. 15, 24 n.8 (1953). The relevant paragraph follows: 
Georgia, Justice Clark in dissent used "conclusory," arguably as his own choice of word, even though he was summarizing the law of the state of Georgia when doing so, to explain that a certain "conclusory pleading" was inadequate. ${ }^{40}$ There is an argument to be made that this is the first original usage of the word for its modern meaning. However, another contender could be the 1956 dissent by Justice Harlan in Griffin v. Illinois. ${ }^{41}$ Justice Harlan described certain "conclusory" allegations as being devoid of substance when stating, "[T] should not be decided without knowing the circumstances underlying the conclusory allegation of "need." "42 The choice of which of these cases should be the winner for the prize of launching "conclusory" into Supreme Court jurisprudence is really irrelevant. Technically, the first occurrence in a Supreme Court opinion was in 1942, but we certainly know that by at least 1956 the Court had begun to use "conclusory" in the manner the word is used, known, and loved or loathed today.

Not surprisingly, usage of the word "conclusory" in legal scholarship correlates with the trends in cases. Table 4 reports the number of articles available in Westlaw's JLR database that include the word "conclusory," aggregated by decade.

We are therefore not required to weigh each finding anew as "clearly erroneous." They were characterized below as "profuse, prolific, and sweeping." We agree. Fed. Rules Civ. Proc., Rule 52(a), 28 U.S.C.A., in terms, contemplates a system of findings which are "of fact" and which are "concise." The well-recognized difficulty of distinguishing between law and fact clearly does not absolve district courts of their duty in hard and complex cases to make a studied effort toward definiteness. Statements conclusory in nature are to be eschewed in favor of statements of the preliminary and basic facts on which the District Court relied.... Otherwise, their findings are useless for appellate purposes. In this particular case, no proper review could be exercised by taking the "fact" findings of "negligence" at face value. And, to the extent that they are of law, or course they are not binding on appeal.

Id.

${ }^{40}$ Williams v. Georgia, 349 U.S. 375, 401 (1955) (Clark, J., dissenting) ("It had been held in at least four prior Georgia decisions that such conclusory pleading of diligence was inadequate to support a motion for a new trial or an extraordinary action for the same.").

${ }^{41}$ Griffin v. Illinois, 351 U.S. 12, 32 (1956) (Harlan, J., dissenting).

${ }^{42} I d$. 
Table 4

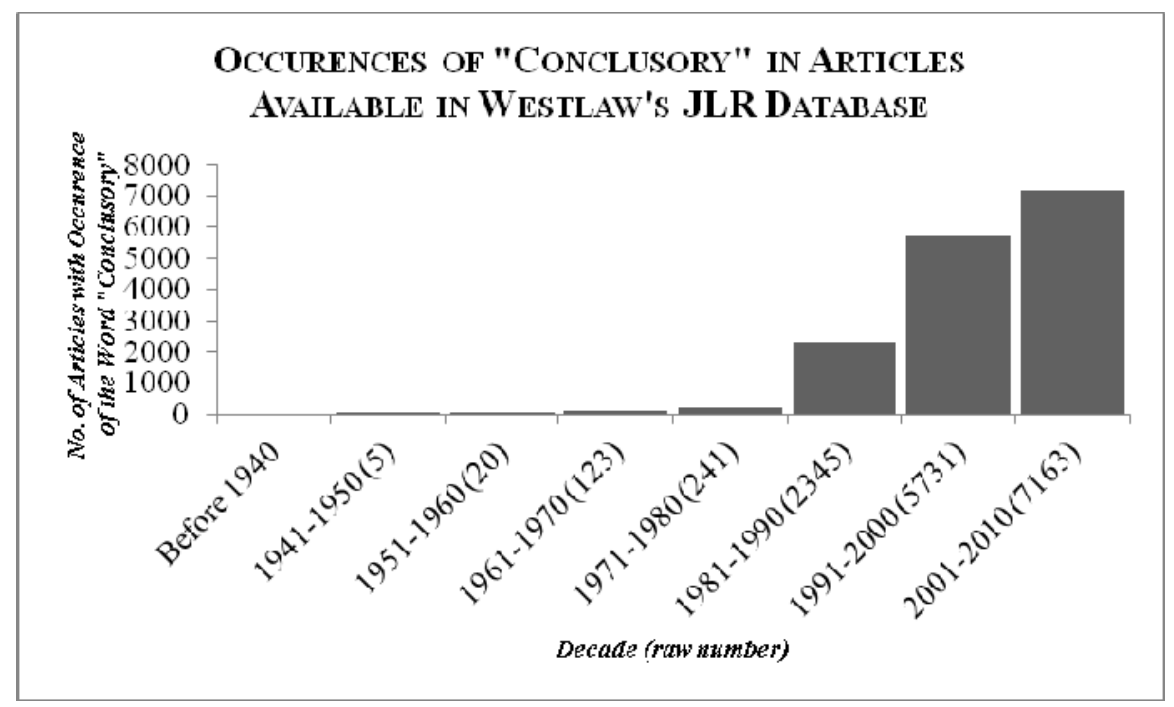

"Conclusory" has appeared in more than 17,000 law review articles, emerging in significant numbers (more than 2300) during scholarship in the 1980s, and with almost 13,000 occurrences between 1991 and the 2010 . $^{43}$

As of this writing, the word "conclusory" has appeared in well over 3000 articles available in Westlaw's JLR database and published in 2008 or later ${ }^{44}$ after Iqbal, it makes sense that its usage would increase dramatically and that it would become more difficult to isolate the usage of the term independent of Iqbal in the future. It should be noted that these tabulations do not take into account the quality, context, or number of occurrences within the tabulated articles. Moreover, Westlaw's JLR database is not comprehensive of legal scholarship, and its coverage and scope is particularly limited when it comes to the number of published materials available in the JLR database from early decades. Nonetheless, the raw usage numbers tell a tale of a word increasingly used and accepted in the legal academy.

Some have noted that "conclusionary" and "conclusional" are viable alternatives to "conclusory." "I5 fact, Black's Law Dictionary recognizes them as

\footnotetext{
${ }^{43}$ Search by author in Westlaw's JLR database (Nov. 22, 2011).

${ }^{44} I d$.

${ }^{45}$ See infra Part IV.
} 
synonyms but describes these words as related to "conclusory," with their independent entries listing as the definitions only the word "conclusory." Nonetheless, a discussion of a few facts about the usage of these two terms is in order. Appendix A shows the unigrams for "conclusional" and "conclusionary" against the unigram for "conclusory," illustrating that they have a much lower frequency of usage in books. A search of Westlaw's ALLCASES retrieves 6720 cases with occurrences of "conclusionary," (although there used to mean "conclusive"). "Conclusionary" appears for the first time in a manner that fits with the traditional legal meaning of a statement without support in $1931 .{ }^{49}$ Westlaw's SCT database retrieves seven relevant Supreme Court cases with occurrences of "conclusionary.. ${ }^{, 0}$ A search of Westlaw's JLR database retrieves 517 articles with occurrences of the term "conclusionary." Westlaw's ALLCASES retrieves 3555 cases with occurrences of "conclusional,",52 with the first occurrence in $1933 .^{53}$ Westlaw's SCT database retrieves nine

${ }^{46}$ BLACK's LaW Dictionary 329 (9th ed. 2009).

${ }^{47}$ Search by author in Westlaw's ALLCASES database (Sept. 1, 2012).

${ }^{48}$ Drummond v. Makaena, 30 Haw. 116, 119 (1927) ("Such decree of the probate court may be received in any case, as evidence (but prima facie evidence merely, not conclusionary) of the truth of the facts therein found.").

${ }^{49}$ Hodges v. Bewley Truesdale Contracting Co., 247 N.Y.S. 414, 419 (N.Y. App. Div. 1931) ("Granting the appropriateness of the quoted paragraph as a conclusionary pleading, no facts of the character which we have suggested are alleged which make the conclusion applicable.").

${ }^{50}$ Search by author in Westlaw's SCT database (Sept. 1, 2012). The seven Supreme Court cases where "conclusionary" appears are Gonzalez v. United States, 553 U.S. 242, 256 (2008) (Scalia, J., concurring) ("precedents ... 'have been brief and conclusionary") (quoting $3 \mathrm{~W}$. LAFAVE ET AL., CRIMINAL PROCEDURE $\S 11.6($ a) at 784, §11.6(c), at 796 (3d ed. 2007)); Bonito Boats, Inc. v. Thunder Craft Boats, Inc., 489 U.S. 141, 164 (1989) (“conclusionary label”); City of Richmond v. J.A. Croson Co., 488 U.S. 469, 500 (1989) ("highly conclusionary statement of a proponent"); MacDonald, Sommer \& Frates v. Yolo Cnty., 477 U.S. 340, 345 n.3 (1986) ("alleging as conclusionary fact") ("conclusionary statement"); $i d$. at 354-57 (White, J., dissenting) (using the phrase "conclusionary allegation" multiple times while quoting the lower court); Bowen v. Roy, 476 U.S. 693, 711 n.18 (1986) (Burger, C.J., plurality opinion) (“conclusionary statement"); Minneapolis \& St. Louis Ry. v. United States, 361 U.S. 173, 173 (1959) ("conclusionary finding of Commission") (headnote only); United States v. Scophony Corp. of America, 333 U.S. 795, 813 (1948) ("conclusionary premise"); and NLRB v. Donnelly Garment Co., 330 U.S. 219, 230 (1947) ("conclusionary evidence"). Note that a search will retrieve nine hits, but two are inapposite - one referring to a final exhibit and used in a Special Master's Report and the other appearing in only a headnote.

${ }^{51}$ Search by author in Westlaw's JLR database (Nov. 22, 2011).

${ }^{52}$ Search by author in Westlaw's ALLCASES database (Sept. 1, 2012).

${ }^{53}$ Child v. Ogden State Bank, 20 P.2d 599, 601 (Utah 1933) ("There is also a field of borderline allegations; some attacked as immaterial, others as being largely in the nature of conclusions, in the 
Supreme Court cases with occurrences of "conclusional." "54 A search of Westlaw's JLR database retrieves eighty-three articles with occurrences of the term "conclusional." 55 All of these numbers are rather paltry compared to the usage data available for the word "conclusory." Although each of those words undoubtedly has its own unique story and the relative value of them has been the subject of conversation in the past, ${ }^{56}$ both because of the predominance of "conclusory" over these alternative terms generally in the language and because of the fact that "conclusory" is the word of choice in Iqbal, a further, more-detailed discussion of these words is beyond the focus of this article.

From courtrooms to classrooms, from briefs to scholarship, and from commentary to conversation and beyond, lawyers (and even lay folk, I contend, but do not here attempt to prove) use the word "conclusory" on a fairly regular basis. Legal-style writers regularly counsel lawyers and law students to avoid phrasing their analysis or arguments in conclusory terms. ${ }^{57}$

The word "conclusory" is clearly quite effusive in legal discourse. Despite this evidence of usage, "conclusory" has battled for legitimacy as a recognized

complaint or petition, and qualified allegations and admissions, and conclusional affirmations and admissions in the answer, difficult to classify.").

${ }^{54}$ Search by author in Westlaw's SCT database (Sept. 1, 2012). The nine Supreme Court cases where "conclusional" appears are Torres v. Oakland Scavenger Co., 487 U.S. 312, 323 (1988) (Brennan, J., dissenting) ("statements ... are wholly conclusional"), superseded by statute, FED. R. APP. 4(a)(3); Henry v. Mississippi, 379 U.S. 443, 461 (1965) (Harlan, J., dissenting) ("cursory and conclusional sentence"); Sanders v. United States, 373 U.S. 1, 22 (1963) ("allegations are vague, conclusional, or inartistically expressed”), superseded by statute, 28 U.S.C. § 2255(h) (2006); Pan Am. World Airways, Inc. v. United States, 371 U.S. 296, 322 (1963) (Brennan, J., dissenting) ("Court does not suggest, except in the vaguest conclusional terms"); United States. v. Loew's, Inc., 371 U.S. 38,40 (1962) ("conclusional finding of fact and law"), abrogated by Ill. Tool Works, Inc., v. Indep. Ink, Inc., 547 U.S. 28 (2006); Wilson v. Schnettler, 365 U.S. 381, 384 (1961) ("Nor did the complaint allege, even in conclusional terms ....”); Minneapolis \& St. Louis Ry. v. United States, 361 U.S. 173, 185 (1959) ("conclusional finding"); United Steelworkers v. United States, 361 U.S. 39, 76 n.12 (1959) (Douglas, J., dissenting) (opinion "stated in an affidavit ... is conclusional only"); United States v. Employing Plasterers Ass'n, 347 U.S. 186, 192 (1954) (Minton, J., dissenting) (“conclusional allegations”).

${ }^{55}$ Search by author in Westlaw's JLR database (Nov. 20, 2011).

${ }^{56}$ See infra Part IV.

${ }^{57}$ See generally, e.g., Bradley G. Clary \& PAMEla LySAUght, SuCCESSFUl LEGAL ANALYSIS AND WRITING: THE FUNDAMENTALS 102 (2d ed. 2006) (“Avoid exaggeration through conclusory modifiers such as 'clearly,' 'plainly,' 'very,' 'obviously,' 'outrageous,' 'unconscionable,' and the like.”); GARNER, REDBOOK 2, supra note 13, at 192, 224 (““[C]learly' [and] 'obviously' [are] weasel words [that] reassure the writer but not the reader. If something is clearly or obviously true, then demonstrate the fact to the reader without resorting to the conclusory use of these words."). 
word. "Frequently, words thought to be new are found to be much older in law than anyone suspected." ${ }^{58}$ That part of the tale continues in Part IV. Before getting there, however, Part II demonstrates the supreme, current importance of the story and summarizes the usage of "conclusory" in the Supreme Court's decisions in Twombly and Iqbal, followed by an explanation in Part III of the theories of meaning in the context of those cases. Usage statistics, of course, only highlight the fact that "conclusory" matters - it remains to be seen what, exactly, "conclusory" means.

\section{II. “CONCLUSORY" IN TWOMBLY AND IQBAL}

Iqbal's usage of "conclusory" hardly constituted the birth of a word, ${ }^{59}$ but it may be the moment by which the word can no longer be ignored. As Part I demonstrates, the Supreme Court has used the word "conclusory" many times before but never in a matter with such dramatic consequences as obtained with its use in Iqbal. Yet, the Court's use of "conclusory" has received only limited attention in the scholarship. Although hundreds of articles have already been written about $I q b a l,{ }^{60}$ more attention has been paid to the Court's "plausibility" inquiry than to its preliminary "conclusory" inquiry, perhaps because many lawyers have been bandying about believing they know what the word "conclusory" means. This article's focus on the history and meaning of the word "conclusory" fills an obvious gap in a growing literature. This section will briefly summarize the changes effectuated by Iqbal and Twombly, highlighting the importance of obtaining a greater understanding of just what "conclusory" means in jurisprudence today.

Twombly and Iqbal have had profound effects ${ }^{61}$ whose universal impact on the whole of pleading practice cannot be overstated. ${ }^{62}$ Given the importance of

\footnotetext{
${ }^{58}$ GARNER, Novelties, supra note 13 , at 331.

${ }^{59}$ But see Jon O. Newman, Birth of a Word, 13 GREEN BAG 2D 169 (2010).

${ }^{60}$ As of this writing there were 942 law review or law journal articles citing Iqbal retrieved in Westlaw's JLR database, with 102 of those appearing in the title field of that search. Search by author in Westlaw's JLR database (Feb. 27, 2011).

${ }^{61}$ Kevin M. Clermont \& Stephen C. Yeazell, Inventing Tests, Destabilizing Systems, 95 IowA L. REV. 821,832 (2010) ("The two cases profoundly changed the law of pleading by adopting a procedural mechanism without precedent in the law.").

${ }^{62}$ Id. at 859 ("Our point is simple: Twombly and Iqbal have introduced a wild card, a factor of substantial instability, at the threshold stage of civil process through which all litigation must pass.”). Spencer also explained well the significance of the cases:
} 
pleading to the operation of our judicial system, the implications affect almost all aspects of the legal world. ${ }^{63}$ These cases are already heavily cited, ${ }^{64}$ and courts are struggling with what has been called a chaotic makeover of the system of pleading. ${ }^{65}$ There is evidence that their application in the lower courts is directly responsible for an increase in dismissals of suits under Rule 12(b)(6). ${ }^{66}$ Aside from that consequence, the confusion with the new standards has taxed the resources of the courts as they struggle to apply the new dictates to thousands of cases on the

\begin{abstract}
Although Twombly and Iqbal do not by themselves supply all one needs to know about pleading doctrine today, the decisions - by largely ratifying the heretofore renegade practice of imposing fact-pleading requirements - have brought together theory and practice in a way that enables a unified analysis of pleading doctrine as stated and the doctrine as applied that will be free of the internal inconsistencies that characterized the pre-Twombly pleading world.... [T] $]$ he merger of rhetoric with reality that Twombly (and Iqbal) accomplished gives us an occasion to assess the precise character, structure, and purpose of pleading doctrine within the federal system as a whole.
\end{abstract}

A. Benjamin Spencer, Understanding Pleading Doctrine, 108 Mich. L. REV. 1, 5 (2009).

${ }^{63}$ Adam N. Steinman, The Pleading Problem, 62 STAN. L. REv. 1293, 1294-95 ("For all intents and purposes, that initial pleading is the key to the courthouse door.").

${ }^{64}$ Id. at 1295-96 ("Twombly has been so influential that it is already among the most frequently cited Supreme Court decisions of all time. It has garnered considerable scholarly attention as well.").

${ }^{65}$ Michael Eaton, The Key to the Courthouse Door: The Effect of Ashcroft v. Iqbal and the Heightened Pleading Standard, 51 Santa Clara L. ReV. 299, 314 (2011) ("Despite the ongoing policy debate, both sides can agree that after Iqbal the pleading standard is notably higher, and a plaintiff seeking judicial redress must satisfy a 'skeptical judicial gatekeeper.'"); Michael S. Pardo, Pleadings, Proof, and Judgment: A Unified Theory of Civil Litigation, 51 B.C. L. REV. 1451, 1451 (2010) ("[Twombly and Iqbal] have injected considerable chaos into the system of civil litigation."); Reinert, supra note 12, at $131 \mathrm{n} .65$ ("There is a broad dispute over whether 'general' allegations of state of mind are sufficient on their own. ... Courts also differ over whether an allegation that a defendant 'knew' or was 'aware' of a particular fact is conclusory or factual."); Victor E. Schwartz \& Christopher E. Appel, Rational Pleading in the Modern World of Civil Litigation: The Lessons and Public Policy Benefits of Twombly and Iqbal, 33 HARV. J.L. \& PUB. POL'Y 1107, 1108-09 (2010) ("Federal pleading requirements have received a modern-day makeover by the United States Supreme Court in [Twombly and Iqbal].”).

${ }^{66}$ Eaton, supra note 65, at 313 ("Following the Supreme Court's decision, Iqbal motions to dismiss became commonplace in federal courts with remarkable speed and success. Five hundred cases cited Iqbal in the two months following the decision, and the number of citations exploded to nearly three thousand by mid-summer 2009."); Patricia W. Hatamyar, The Tao of Pleading: Do Twombly and Iqbal Matter Empirically?, 59 AM. U. L. REV. 553, 557 (2010) (“... Twombly and Iqbal have significantly increased the rate at which 12(b)(6) motions have been granted by district courts ... [T] [is result, if desirable, should be accomplished by the normal rule amendment process rather than by a ruling of the Court."). See also id. at 581-82 ("The courts of appeals have been quick to notice a sea change in Iqbal ... [and] it appears that district courts after Iqbal are granting 12(b)(6) motions at a much higher rate than they did under either Conley or Twombly."). 
docket. ${ }^{67}$ Lawyers are still struggling to understand what Twombly and Iqbal mean for litigation, ${ }^{68}$ some latching on to it as a tool to seek dismissals and others navigating the standards to avoid having their clients' cases thrown out. ${ }^{69}$ Academics too are trying to provide guidance on what some see as revolutionary changes in the law of procedure. ${ }^{70}$

The analysis of Twombly and Iqbal has been extensive ${ }^{71}$ and overwhelmingly critical, ${ }^{72}$ including concerns over the new pleading standard's lack of clarity, ${ }^{73}$ its

${ }^{67}$ Reinert, supra note 12, at $121 \mathrm{n} .11$ ("To be fair, the Supreme Court itself stated that it did not consider Twombly or Iqbal to break significant new ground . . . and some lower courts seem to be taking the Court at its word .... The dissenters in Iqbal took a sharply different view . . . and many lower courts have explicitly acknowledged the significant difference between adjudicating pleading motions before and after these decisions."); Schwartz \& Appel, supra note 65, at 1109 ("[The new standard] has resulted in significant confusion as lower courts attempt to decipher its meaning and impact."); Spencer, supra note 62, at 7 ("Lower courts have been confused by these mixed signals, causing them to reach varying conclusions about whether notice pleading remains or has been supplanted by something new.").

${ }^{68}$ Reinert, supra note 12, at 121 ("The shift from Conley to Iqbal/Twombly pleading has created controversy and confusion throughout the legal world, both as to whether the recent decisions are meaningfully different from past practice and as to whether anything should be done in response.").

${ }^{69}$ Hatamyar, supra note 66, at 582-83 ("The fact that district courts rarely segregate "conclusions" in pleadings after Iqbal may simply be due to the nature of the task which can be highly time-consuming without counsel's help. As the defense bar absorbs Iqbal's teaching, we may see more motions assisting the judge in identifying so-called "conclusions" that should be ignored.").

${ }^{70}$ Clermont \& Yeazell, supra note 61, at 823 ("The Court has revolutionized the law on pleading.... By inventing a new and foggy test for the threshold stage of every lawsuit, they have destabilized the entire system of civil litigation.... [W] [Werever you stand on pleading ... you should lament these recent decisions.").

${ }^{71}$ Eaton, supra note 65, at 315 ("While Iqbal appears to have retired notice pleading wholesale, a growing scholarly debate has emerged over the proper interpretation of Iqbal's effect on pleading standards."); Steinman, supra note 63, at $1296 \mathrm{nn} .10$ and 12 (listing representative recent scholarship on Twombly and Iqbal).

${ }^{72}$ Stephen R. Brown, Reconstructing Pleading: Twombly, Iqbal, and the Limited Role of the Plausibility Inquiry, 43 AKRON L. REV. 1265, 1266 (2010) (providing a string of quotations from the "deluge of criticism" that has followed Twombly and Iqbal); Edward A. Hartnett, Taming Twombly, Even After Iqbal, 158 U. PA. L. REV. 473, 474 (2010) (“Scholarly reaction to Twombly has been largely critical.").

${ }^{73}$ Robert G. Bone, Plausibility Pleading Revisited and Revised: A Comment on Ashcroft v. Iqbal, 85 Notre DAmE L. Rev. 849, 867 (2010) (“Iqbal's two-pronged approach is incoherent."); Clermont \& Yeazell, supra note 61, at 838 ("The Supreme Court's insistence on nonconclusory statements and testing for a reasonable inference combine to create a novel test. Indeed, it is so novel that if it prevails, we will have a procedural revolution on our hands."). 
seemingly negative effects on access to the courts, ${ }^{74}$ and its broadening of the power and discretion available to judges. ${ }^{75}$ Still, some applaud the Twombly/Iqbal standard as putting a much-needed and long-overdue check on out-of-control litigation and frivolous lawsuits. ${ }^{76}$

In this section, portions of the opinions in Twombly and Iqbal where use of the term "conclusory" appears will at times be quoted at length, in part because this article concludes that contextual analysis may be our only hope for gaining a semblance of understanding of what the word means in the context of judicial review of the sufficiency of pleadings.

In Twombly, the court analyzed the sufficiency of pleadings in an antitrust claim under $\S 1$ of the Sherman Act. The case involved conspiracy to prevent competitive entry into certain local telephone and internet service markets, among other claims. ${ }^{77}$ Applauded by some and bemoaned by others for introducing the concept that a court may review the pleadings in a complaint for their plausibility when considering a motion to dismiss for failure to state a claim, there are hints about the importance of understanding the meaning of the term "conclusory" throughout the Twombly opinion. The Twombly Court explained that a complaint "requires more than labels and conclusions, and a formulaic recitation of the elements of a cause of action will not do." ${ }^{, 78}$ The Twombly Court cautioned that its plausibility review standard was not giving license for a savvy judge to question the probability of proof of stated facts. ${ }^{79}$ The Twombly Court found that

\footnotetext{
${ }^{74}$ Hatamyar, supra note 66, at 580 ("Because it places no limit on what a judge may or may not accept as true, or what it may or may not call a legal conclusion, Iqbal opens the door for much wider rejection, on an ill-defined basis, of a plaintiff's allegations on a defendant's 12(b)(6) motion.").

${ }^{75}$ Id. at 555 ("If Twombly caused a shock, Iqbal struck a blow. A firestorm of protest ensued over Iqbal's alleged judicial activism.”); Rajov Mohan, A Retreat from Decision by Rule in Ashcroft v. Iqbal, 129 S. Ct. 1937 (2009), 33 HARV. J.L. \& PUB. POL'y 1191, 1195-96 (2010) (“In expounding on the plausibility standard in Iqbal, the Supreme Court did little to resolve Twombly's uncertainty and simultaneously confounded what little clarity Twombly had preserved. As a result, pleading doctrine has moved away from decision by rule and toward a highly discretionary standard.").

${ }^{76}$ See, e.g., Schwartz \& Appel, supra note 65, at 1109 ("Although the contours of Twombly and Iqbal may not yet be fully understood, the Supreme Court's purpose in developing a more careful judicial review of pleadings was clear: more thorough review is necessary to protect against frivolous and purely speculative lawsuits.").

${ }^{77}$ Bell Atlantic Corp. v. Twombly, 550 U.S. 544 (2007).

${ }^{78} I d$. at 555.

${ }^{79}$ The Twombly Court explained:
}

In applying these general standards to a $\S 1$ claim, we hold that stating such a claim requires a complaint with enough factual matter (taken as true) to 
"conclusory allegation of agreement at some unidentified point does not supply facts adequate to show illegality" sufficient to show that conspiracy existed under $\S 1$ of the Sherman Act. ${ }^{80}$ As the Court further explained, "In identifying facts that are suggestive enough to render a $\S 1$ conspiracy plausible ... [i]t makes sense to say ... that an allegation of parallel conduct and a bare assertion of conspiracy will not suffice. Without more, parallel conduct does not suggest conspiracy." ${ }^{\prime 1}$ The Court declared that a mere statement of parallel conduct was the equivalent of a "a naked assertion of conspiracy in a $\S 1$ complaint: it gets the complaint close to stating a claim, but without some further factual enhancement it stops short of the line between possibility and plausibility of "entitle[ment] to relief.", 82 In so doing, the Twombly Court explained that the complaint must cross a borderline "between the conclusory and the factual. Here it lies between the factually neutral and the factually suggestive. Each must be crossed to enter the realm of plausible liability." ${ }^{~} 83$ Except from what can be inferred from the context of its usage, Twombly offered no definition for "conclusory."

The Twombly dissent used the word "conclusory" only once. Discussing the limited notice pleading required under Rule 8 and its seeming rejection of a fact/conclusion distinction, the Twombly dissent quoted a Seventh Circuit decision stating, "The Federal Rules of Civil Procedure establish a system of notice pleading rather than of fact pleading, ... so the happenstance that a complaint is "conclusory," whatever exactly that overused lawyers' cliché means, does not

suggest that an agreement was made. Asking for plausible grounds to infer an agreement does not impose a probability requirement at the pleading stage; it simply calls for enough fact to raise a reasonable expectation that discovery will reveal evidence of illegal agreement. And, of course, a well-pleaded complaint may proceed even if it strikes a savvy judge that actual proof of those facts is improbable, and "that a recovery is very remote and unlikely."

Id. at 556 .

${ }^{80} I d$. at 557.

${ }^{81} \mathrm{Id}$. at $556-57$.

${ }^{82} I d$. at 557.

${ }^{83}$ Id. at 557 n.5 (citing DM Research, Inc. v. College of Am. Pathologists, 170 F.3d 53, 56 (1st Cir. 1999)) (“'T] $]$ erms like 'conspiracy,' or even 'agreement,' are border-line: they might well be sufficient in conjunction with a more specific allegation-for example, identifying a written agreement or even a basis for inferring a tacit agreement, ... but a court is not required to accept such terms as a sufficient basis for a complaint."). See also Spencer, supra note 62, at 12 ("Twombly suggested that conclusory terms could not be made to do the work of actual fact allegations."). 
automatically condemn it." ${ }^{, 84}$ After Twombly and Iqbal, evidently the word does cause such condemnation, "cliché" or not.

Where Twombly used but did not shout the word "conclusory" as critical, Iqbal makes clear that, whatever it means, the Court intended to take the word "conclusory" very seriously. Twombly hinted at the importance of the meaning of "conclusory" to judicial review of the sufficiency of pleading, but it was Iqbal that brought it front and center. ${ }^{85}$ Although Iqbal clearly attempts to fill in some gaps left open in Twombly, it is safe to say that Iqbal both clarified and complicated the matter. $^{86}$

Javaid Iqbal, a citizen of Pakistan and a Muslim, sued officials of the United States government on various theories of deprivation of constitutional protection while in federal custody under pre-trial detention. ${ }^{87}$ Iqbal was one of the "high interest" detainees held as the result of FBI investigations that occurred shortly after September 11, 2001. ${ }^{88} \mathrm{He}$ was charged with "fraud in relation to identification documents and conspiracy to defraud the United States" and was held in the maximum-security center at the Metropolitan Detention Center in Brooklyn, New York, pending trial. ${ }^{89}$ The conditions were strict for "high interest" detainees like Iqbal, including twenty-three hour lockdowns with one hour "outside their cells in

${ }^{84}$ Id. at 590 (Stevens, J., dissenting) (citing Brownlee v. Conine, 957 F.2d 353, 354 (7th Cir. 1992)).

${ }^{85}$ See Hatamyar, supra note 66, at 575 ("[Iqbal is an] extraordinary interpretation of Twombly and federal pleading practice - refuted bitterly in dissent .... [It took the 12(b)(6) standard to] new heights.").

${ }^{86}$ Twombly, 550 U.S. at 556. I conclude, as have other commentators, that although courts continued to pay lip service to the "notice pleading" ideal of Conley, in practice, the standard was seriously eroded by the time Twombly was decided. Iqbal, though, contains not even a passing reference to notice pleading, and may portend the end of this liberal regime in the federal courts. See also Reinert, supra note 12, at 130 (" $[\mathrm{T}]$ he Court adopted a 'plausibility' standard in an antitrust case ... . The Court's decision in Iqbal closed a theoretical door, left open in Twombly, by making it clear that plausibility pleading applied in all civil cases, not just antitrust claims."); Eaton, supra note 65, at 310 ("[The] court rejected the argument that it was imposing a Rule 9(b) particularity requirement, when Rule 8 only requires malice, intent, and knowledge to be alleged generally.").

${ }^{87}$ Ashcroft v. Iqbal, 556 U.S. 662, 667 (2009). The court phrased the issue in the case as follows: "Did respondent, as the plaintiff in the District Court, plead factual matter that, if taken as true, states a claim that petitioners deprived him of his clearly established constitutional rights" and held the "pleadings were insufficient." Id. At issue was a claim under Bivens v. Six Unknown Fed. Narcotics Agents, 403 U.S. 388 (1971).

${ }^{88} \mathrm{Iqbal}, 556$ U.S. 662, 666.

${ }^{89} \mathrm{Id}$. at 667. 
While EFfuSiVE, “CONCLUSORY” IS STIL L E L U IVE

\begin{tabular}{l|lll}
$P$ A G E & 24 & $\mathbf{1}$
\end{tabular}

handcuffs and leg irons accompanied by a four-officer escort." ${ }^{90}$ Iqbal brought a Bivens action after pleading guilty, serving his sentence, and being removed back to Pakistan. ${ }^{91}$

Iqbal filed a complaint that focused on discriminatory treatment and unconstitutional conditions while in maximum-security confinement. ${ }^{92}$ The Supreme Court confined its review to the relevant allegations against only the petitioner-defendants before it, those that had been subject to the motion to dismiss for failure to state a claim and that were deemed sufficient by the District Court and the Second Circuit. ${ }^{93}$

The Court established a two-pronged test for evaluating the sufficiency of allegations. In summary, it described the two-pronged approach as follows:

In keeping with these principles a court considering a motion to dismiss can choose to begin by identifying pleadings that, because they are no more than conclusions, are not entitled to the assumption of truth. While legal conclusions can provide the framework of a complaint, they must be supported by factual allegations. When there are well-pleaded factual allegations, a court should assume their veracity and then determine whether they plausibly give rise to an entitlement to relief. ${ }^{94}$

The Court claimed to be interpreting its standard established in Twombly and also made clear that the new test was generally applicable, laying to rest curiosities as to whether Twombly could be limited to antitrust actions. ${ }^{95}$

First, the Court summarized the basics of the pleading standard under Rule 8 after Twombly:

To survive a motion to dismiss, a complaint must contain sufficient factual matter, accepted as true, to "state a claim to relief that is plausible on its face." A claim has facial plausibility when the plaintiff pleads factual content that allows

\footnotetext{
${ }^{90} I d$. at 668 .

${ }^{91} I d$. at 669.

${ }^{92} I d$. at 666.

${ }^{93} I d$. at $666-69$.

${ }^{94} I d$. at 679. But see Hatamyar, supra note 66, at 580 (arguing that Iqbal misread Twombly).

${ }^{95} I d$. at 684 .
} 
U N I V E R S I T Y O F P I T T S B U R G H L A W R E V I E W

PAGE

the court to draw the reasonable inference that the defendant is liable for the misconduct alleged. The plausibility standard is not akin to a "probability requirement," but it asks for more than a sheer possibility that a defendant has acted unlawfully. Where a complaint pleads facts that are "merely consistent with" a defendant's liability, it "stops short of the line between possibility and plausibility of "entitlement to relief.",96

Next, the Iqbal Court clarified the underlying "working principles" after Twombly, stressing that Twombly stands for the proposition that conclusory allegations are insufficient to state a claim for relief, thus establishing the first prong:

Two working principles underlie our decision in Twombly. First, the tenet that a court must accept as true all of the allegations contained in a complaint is inapplicable to legal conclusions. Threadbare recitals of the elements of a cause of action, supported by mere conclusory statements, do not suffice. (Although for the purposes of a motion to dismiss we must take all of the factual allegations in the complaint as true, we "are not bound to accept as true a legal conclusion couched as a factual allegation. ...") ${ }^{97}$

The Court stated further that "a plaintiff armed with nothing more than conclusions" cannot "unlock the doors of discovery.",98

The Iqbal Court then explained the second prong of the sufficiency inquiry as requiring that a complaint satisfy plausibility review:

Second, only a complaint that states a plausible claim for relief survives a motion to dismiss. Determining whether a complaint states a plausible claim for relief will . . . be a context-specific task that requires the reviewing court to draw on its judicial experience and common sense. But where the well-pleaded facts do not permit the court to infer more than the mere possibility of misconduct, the complaint has alleged - but it has not "show[n]"- "that the pleader is entitled to relief." 99

\footnotetext{
${ }^{96} I d$. at 678 (citations omitted).

${ }^{97}$ Id. (citations omitted).

${ }^{98} I d$. at 679.

${ }^{99} I d$. at 679 (citations omitted).
} 
The plausibility review prong has itself garnered a great deal of confusion, but this article focuses on the "conclusory" prong only.

The Iqbal court then proceeded to distinguish between conclusory and "nonconclusory" allegations in the complaint at bar. It applied the first prong and identified "the allegations in the complaint that are not entitled to the assumption of truth," 100 basing that identification on the finding that the following allegations met the definition of "conclusory":

Respondent pleads that petitioners "knew of, condoned, and willfully and maliciously agreed to subject [him]" to harsh conditions of confinement "as a matter of policy, solely on account of [his] religion, race, and/or national origin and for no legitimate penological interest." The complaint alleges that Ashcroft was the "principal architect" of this invidious policy, and that Mueller was "instrumental" in adopting and executing it. These bare assertions, much like the pleading of conspiracy in Twombly, amount to nothing more than a "formulaic recitation of the elements" of a constitutional discrimination claim, namely, that petitioners adopted a policy “"because of,' not merely 'in spite of,' its adverse effects upon an identifiable group." As such, the allegations are conclusory and not entitled to be assumed true. ${ }^{101}$

The Court cautioned that its identification and determination that the listed allegations were conclusory did not invite a wholesale speculation on the merits of the claim:

To be clear, we do not reject these bald allegations on the ground that they are unrealistic or nonsensical. We do not so characterize them any more than the Court in Twombly rejected the plaintiffs' express allegation of a "contract, combination or conspiracy to prevent competitive entry," because it thought that claim too chimerical to be maintained. It is the conclusory nature of respondent's allegations, rather than their extravagantly fanciful nature, that disentitles them to the presumption of truth. ${ }^{102}$

\footnotetext{
${ }^{100} \mathrm{Id}$. at 680.

${ }^{101} I d$. at 680-81 (citations omitted).

${ }^{102} I d$. at 681 (citations omitted).
} 
U N I V E R S I T Y O F P I T T S B U R G H L A W R E V I E W

PAGE

This statement places a check on the application of the conclusory and plausibility prongs, explaining that a judge should not be attempting to prejudge the outcome of a case or inject their own beliefs on the wisdom of the litigation itself.

The Court determined the remaining allegations were nonconclusory and proceeded to the second prong of the Iqbal inquiry to "consider the factual allegations in respondent's complaint to determine if they plausibly suggest an entitlement to relief." ${ }^{103}$ According to the Court, the following allegations were nonconclusory:

The complaint alleges that "the $[\mathrm{FBI}]$, under the direction of Defendant MUELLER, arrested and detained thousands of Arab Muslim men ... as part of its investigation of the events of September 11." It further claims that " $[t]$ he policy of holding post-September-11th detainees in highly restrictive conditions of confinement until they were 'cleared' by the FBI was approved by Defendants ASHCROFT and MUELLER in discussions in the weeks after September 11, 2001."104

After an extensive evaluation of the allegations and an application of its standards for plausibility, these nonconclusory allegations were insufficient to satisfy the Court's plausibility test. ${ }^{105}$ The Court's plausibility analysis in Iqbal has been the subject of much commentary, but that test, again, is beyond the scope of this article. Nonetheless, it is critical to examine the allegations it chose to identify as nonconclusory and subject to plausibility review in order to understand the Court's analysis under the "conclusory" prong. A comparison between those allegations it deemed conclusory and those it deemed nonconclusory is the best chance for discerning some sense of what it takes to plead something that will survive the first prong. ${ }^{106}$

${ }^{103} I d$.

${ }^{104} I d$. (citations omitted).

${ }^{105}$ Id. ("Taken as true, these allegations are consistent with petitioners' purposefully designating detainees 'of high interest' because of their race, religion, or national origin. But given more likely explanations, they do not plausibly establish this purpose.").

${ }^{106}$ Suzanna Sherry, Foundational Facts and Doctrinal Change, 2011 U. ILL. L. REv. 145, 177 (2011) ("This allegation-by-allegation consideration will further ratchet up the scrutiny that judges accord to complaints."). 
While EFfuSiVE, “CONCLUSORY” IS STIL L E L U IVE

\begin{tabular}{l|lll}
$P$ A G E & $\mathbf{2} 4 \mathbf{5}$
\end{tabular}

At the end of the majority opinion, the Iqbal Court rejected criticism that its test created a heightened pleading standard. ${ }^{107}$ The insufficiency of conclusory allegations was grounded in an interpretation of Rule 8, and Rule 9's allowance for some "general allegation[s]" provides no refuge for plaintiffs with cases operating under the applicable normal standard, rather than an elevated or particularized standard:

Respondent finally maintains that the Federal Rules expressly allow him to allege petitioners' discriminatory intent "generally," which he equates with a conclusory allegation. It follows, respondent says, that his complaint is sufficiently well pleaded because it claims that petitioners discriminated against him "on account of [his] religion, race, and/or national origin and for no legitimate penological interest." Were we required to accept this allegation as true, respondent's complaint would survive petitioners' motion to dismiss. But the Federal Rules do not require courts to credit a complaint's conclusory statements without reference to its factual context .... Rule 9 merely excuses a party from pleading discriminatory intent under an elevated pleading standard. It does not give him license to evade the less rigid - though still operativestrictures of Rule $8 \ldots$ And Rule 8 does not empower respondent to plead the bare elements of his cause of action, affix the label "general allegation," and expect his complaint to survive a motion to dismiss. ${ }^{108}$

On this basis, the Court at least claims that it was neither rewriting the Federal Rules of Civil Procedure nor creating a heightened pleading standard when establishing the two-pronged Iqbal test. ${ }^{109}$ Instead, the Court maintained that it had retained the basic principles of pleading and was simply clarifying the lens by which existing sufficiency standards should be viewed. ${ }^{110}$

While not explicitly rejecting the conclusory standard, the dissenting opinions on several occasions disagreed with whether such a test as applied to the allegations in the case amount to conclusory statements. In doing so, the dissent on several occasions placed the word "conclusory" alone in quotation marks, perhaps

${ }^{107}$ Iqbal, 556 U.S. at $686-87$.

${ }^{108} I d$. (citations omitted).

${ }^{109} I d$.

${ }^{110} I d$. 
U N I V E R S I T Y O F P I T T S B U R G H L A W R E V I E W

PAGE

indicating derision for the term or its inability to serve as a standard with precision. $^{111}$

The precise claims that the majority's eyes found to be conclusory were seen as nonconclusory through the dissent's viewfinder. The dissent criticized the majority's plausibility analysis because it lacked inclusion of the other allegations, which the majority had rejected outright as conclusory. ${ }^{112}$ Importantly, the Iqbal dissent did not reject the majority's proposition that conclusory allegations should be disregarded. So both the dissent and the majority accept a pleading standard that filters out conclusory allegations. In fact, arguably, the dissent does not even reject the majority's definition of the word "conclusory" to the extent one could be implicitly discerned from the majority's opinion.

However, the dissent believed that (1) whether something is or is not conclusory must be determined in light of the complaint as a whole; ${ }^{113}$ and, perhaps more importantly, that (2) the majority had no principled basis for its categorization in this case. ${ }^{114}$ First, in discussing the allegations that the majority called "bare assertions," the dissent claimed that every assertion must be deemed conclusory or nonconclusory in light of the whole complaint in context:

The fallacy of the majority's position, however, lies in looking at the relevant assertions in isolation. The complaint contains specific allegations that, in the aftermath of the September 11 attacks, the Chief of the FBI's International Terrorism Operations Section and the Assistant Special Agent in Charge for the FBI's New York Field Office implemented a policy that discriminated against Arab Muslim men, including Iqbal, solely on account of their race, religion, or national origin. Viewed in light of these subsidiary allegations, the allegations singled out by the majority as "conclusory" are no such thing ... . Taking the

\footnotetext{
${ }^{111}$ The quotation marks around "conclusory" in this article are not intended to so question the validity of the word but rather are merely a means of isolating the word and also indicating the focus on the word as a word.

${ }^{112}$ Iqbal, 556 U.S. at 697 (Souter, J., dissenting) ("But these allegations do not stand alone as the only significant, nonconclusory statements in the complaint, for the complaint contains many allegations linking Ashcroft and Mueller to the discriminatory practices of their subordinates.").

${ }^{113} I d$. at 698 .

${ }^{114} I d$. at 699 .
} 
While EFfuSiVE, “CONCLUSORY” IS STIL L E L U IVE

\begin{tabular}{l|lll}
$P$ A G E & 24 & 7
\end{tabular}

complaint as a whole, it gives Ashcroft and Mueller "ffair notice of what the ... claim is and the grounds upon which it rests.",115

The dissent believed that the support necessary to make a statement nonconclusory can be found not just in what is stated in the specific numbered paragraph of the complaint where the allegation is stated but also in all of the surrounding allegations.

Perhaps more concerning for litigants attempting to discern any meaning from Iqbal, Souter concluded that, even looking at the allegations in isolation that were rejected by the majority as conclusory, "the majority's holding that the statements it selects are conclusory cannot be squared with its treatment of certain other allegations in the complaint as nonconclusory." ${ }^{116}$ Souter proceeded to explain his confusion with the majority's apparent definitional application of "conclusory":

For example, the majority takes as true the statement that "[t]he policy of holding post-September-11th detainees in highly restrictive conditions of confinement until they were 'cleared' by the FBI was approved by Defendants ASHCROFT and MUELLER in discussions in the weeks after September 11, 2001." This statement makes two points: (1) after September 11, the FBI held certain detainees in highly restrictive conditions, and (2) Ashcroft and Mueller discussed and approved these conditions. If, as the majority says, these allegations are not conclusory, then I cannot see why the majority deems it merely conclusory when Iqbal alleges that (1) after September 11, the FBI designated Arab Muslim detainees as being of " "high interest" "because of the race, religion, and national origin of the detainees, and not because of any evidence of the detainees' involvement in supporting terrorist activity," and

${ }^{115}$ Id. at $698-99$.

Iqbal's claim is not that Ashcroft and Mueller "knew of, condoned, and willfully and maliciously agreed to subject" him to a discriminatory practice that is left undefined; his allegation is that "they knew of, condoned, and willfully and maliciously agreed to subject" him to a particular, discrete, discriminatory policy detailed in the complaint. Iqbal does not say merely that Ashcroft was the architect of some amorphous discrimination, or that Mueller was instrumental in an ill-defined constitutional violation; he alleges that they helped to create the discriminatory policy he has described.

Id. at 698-99.

${ }^{116} I d$. at 699. 
(2) Ashcroft and Mueller "knew of, condoned, and willfully and maliciously agreed" to that discrimination. ${ }^{117}$

Souter concluded that " $[\mathrm{b}] \mathrm{y}$ my lights, there is no principled basis for the majority's disregard of the allegations linking Ashcroft and Mueller to their subordinates' discrimination." $" 118$

In Iqbal, the issue of whether certain allegations were conclusory was the main point of contention between the majority and dissent. ${ }^{119}$ Souter could not see a principled, discernable standard in the majority opinion for conclusory versus nonconclusory allegations. ${ }^{120}$ Souter believed that the majority's application of the conclusory standard was inappropriate because a court must look at an allegation's place in the whole complaint before it can decide whether or not it is conclusory. ${ }^{121}$

${ }^{117} I d$. (citations omitted).

${ }^{118} I d$.

119 Brown, supra note 72, at 1283 (“[T] he disagreement in Iqbal was solely over the majority's disregarding of certain allegations as conclusory.”); Clermont \& Yeazell, supra note 61, at 841 ("Justice Souter in his dissent argued that the majority in Iqbal wrongly defeated the complaint not by manipulating plausibility, but by sweeping out all sorts of good allegations as 'conclusory."'); Hartnett, supra note 72, at 492 ("Some, including the dissenting Justices, see no basis for treating the first set of allegations, but not the second set of allegations, as 'conclusory."').

${ }^{120}$ Hatamyar, supra note 66, at 581. Hatamyar explained Souter's decision favorably as follows:

Justice Souter, in dissent, disagreed that any of the complaint's allegations were "conclusory," and argued that there was "no principled basis" for the distinction that the majority made between conclusory and nonconclusory allegations. He considered the majority's "singl[ing] out" of certain allegations "in isolation," rather than viewing the complaint as a whole, a "fallacy." But it was more than that; the majority's decision overturned a long-accepted principle on 12(b)(6) motions that when considering a motion to dismiss under Rule 12(b)(6), the court must "[v]iew [] the complaint as a whole, rather than any one statement in isolation." Iqbal explicitly encourages judges to view the non-conclusory allegations in isolation from the conclusory allegations. Just as juries are more likely to rule for the defendant if they have to use a special verdict or answer special interrogatories (rather than give a general verdict), I can only see the "twopronged approach" working in favor of defendants.

Id.

${ }^{121}$ Bone, supra note 73 , at 858 . Bone explained that:

With regard to the pleading issue, Souter agreed that the complaint, stripped of its key allegations, would not meet a plausibility standard, but he strongly disagreed that the key allegations should be ignored as conclusory. If read in 
While EFfuSiVE, “CONCLUSORY” IS STIL L E L U IVE

Nine sets of eyes read the same complaint, and in relation to one word's meaning-"conclusory"- four saw mountains that break the threshold of sufficiency, but a controlling five saw mere mole hills that were bumps worthy of nothing more than disregard. We are left with none of the Justices really telling us what "conclusory" means, but each knowing when or if they saw it.

A key question after Iqbal becomes why some allegations were deemed conclusory and not others. On what basis did the court distinguish these allegations? Unfortunately, the opinions themselves leave litigators with little guidance in that regard.

Several authors have generated summaries of the state of the law after Iqbal, and a few offer guidance which essentially calls upon the risk-averse litigator to overcompensate with what is included in a complaint to offset the uncertainty engendered by the decision. Clermont and Yeazell, for example, summarized the state of the law after Iqbal and cautioned that:

Practically ... the plaintiff must now do more to identify the complaint's legal theories, doing so well enough for the judge to weigh their factual sufficiency. Second, as to factual sufficiency, the plaintiff practically must plead facts and even some evidence. The plaintiff should give a particularized mention of the factual circumstances of each element of the claim. ${ }^{122}$

Hatamyar has her own version of "where we are now," counseling in light of the confusion with Iqbal that "[c]ourts do not require 'heightened specificity,' but 'conclusions' are unacceptable. Never mind that if the pleader is concerned that an allegation is 'conclusory,' she would probably attempt to remedy it by making the allegation more specific." 123 Before dumping the kitchen sink into a complaint, however, one can hope that some guidance can be found to navigate through civil procedure after Iqbal.

The remaining Parts of this article will further examine "conclusory" with that goal in mind. "Conclusory" may be a term that evades neutral or principled definitional application. It may be nothing more than something that litigants aspire

isolation, they might seem conclusory, Souter argued, but when read in the context of the complaint as a whole, they were quite specific.

Id.

${ }^{122}$ Clermont \& Yeazell, supra note 61, at 830.

${ }^{123}$ Hatamyar, supra note 66, at 583. 
against without knowing entirely how to avoid. Parts III and beyond look at the attempts to discern some definition of the term that can serve as guidance after Iqbal.

\section{SELECTED INTERPRETATIONS OF WHAT "CONCLUSORY" Means in THE CONTEXT OF IQBaL's Pleading STANDARD}

Iqbal was primarily a decision centered on what is or is not conclusory, ${ }^{124}$ even though it did not tell us much about the meaning of that term and despite the fact that the Court's analysis on the "conclusory" test has received much less concentrated attention in the scholarly literature than the Court's plausibility analysis. What allegations can be disregarded as conclusory is, in fact, the "most pressing doctrinal question" in the post-Iqbal world. ${ }^{125}$ Defining "conclusory" is not easy, but the decision in Iqbal necessitates an attempt. " ${ }^{126}$ "Conclusory" versus "nonconclusory" may just be the latest iteration of a growing number of ways in which the court attempts to distinguish between those allegations that must be accepted as true and those that do not, ${ }^{127}$ but it is the standard litigants face in today's post-Iqbal world.

\footnotetext{
${ }^{124}$ Steinman, supra note 63, at 1316 ("[T] he key allegations in both Iqbal and Twombly were not disregarded because they were implausible. They were disregarded because they were conclusory. This forced the Court to inquire whether the allegations that remained — standing alone - plausibly suggested the existence of a discriminatory motive (Iqbal) or a conspiracy (Twombly).") (emphasis omitted); Eaton, supra note 65, at 317 ("Steinman believes the Court dismissed the claims in both cases because they were conclusory, not because they were implausible.").

${ }^{125}$ Steinman, supra note 63, at 1299-1300 ("Iqbal's most pressing doctrinal question [is] how to determine whether a particular allegation may be disregarded as 'conclusory,' i.e., a mere legal conclusion.”).

${ }^{126}$ Brown, supra note 72, at 1286 ("Defining conclusory is a difficult task, partly because the Federal Rules attempted to move away from the language of 'facts,' 'ultimate facts,' and 'conclusions' with Rule 8(a)'s short-plain-statement language.”).

${ }^{127}$ Hatamyar makes the point that the Court has described its dichotomy in different ways in the past:

\begin{abstract}
Whatever its source, the dividing line between allegations accepted and not accepted as true has been phrased in a myriad of ways. The characterization of allegations accepted as true has run the gamut from "all allegations" to "all material allegations" to "facts" to "all factual allegations" to "all wellpleaded factual allegations." The characterization of allegations that a court is not bound to accept as true has ranged from "legal conclusions" to "sweeping legal conclusions" to "bare assertion[s]" to "bare assertion[s] of legal conclusions" to "bald assertions [and] unsupportable conclusions" to "conclusory allegations" to "conclusory recitations of law" to "legal conclusion[s] couched as [or "masquerading as'] fact[s]" to my personal favorite, "periphrastic circumlocutions."
\end{abstract}


While EFfuSiVE, “CONCLUSORY” IS STIL L E L U IVE

P A G E $\mid \begin{array}{lll}2 & 51\end{array}$

\section{A. The Meaning of "Conclusory" Discerned from the Text of the Court's Opinion in Iqbal}

Beyond identification and isolation of allegations into the categories "conclusory" and "nonconclusory," the Iqbal Court did not attempt to further define generally the material it understood to be within these shorthand descriptions for purposes of future cases. The Court's decisions in Iqbal and Twombly claim not to create a heightened pleading standard, but it is hard to see how they did not with their disregard for so-called conclusory allegations. ${ }^{128}$ However, even generously accepting that the standard was not heightened after Iqbal, the need to understand the meaning of the qualifier "conclusory" was at the very least amplified. ${ }^{129}$ The best place to start to discern some meaning for the term is in the Court's opinions themselves. Professor Brown contends that "[b]ecause this line between the conclusory and the factual appears to have been drawn (or at least received significant attention) for the first time in Iqbal, its definition must be found there." 130 There is, unfortunately, little definitional guidance to be found within the opinions.

Several key passages from Iqbal using "conclusory" have catapulted the importance of its meaning. The Iqbal Court first uses the word "conclusory" when trying to define the meaning of the holding in Twombly, where we can discern that "conclusory" means, at least in the pleading context, "[t]hreadbare recitals of the elements of a cause of action,"131 "[1]egal conclusion[s] couched as ... factual allegation[s],"132 or something presented by the plaintiff that provides "[n]othing more than conclusions." ${ }^{133}$ As the Court continues, we see some other possible assistance with the definition of "conclusory." One passage surrounding the interpretation of "conclusory" seems to imply that the term could include

Hatamyar, supra note 66 , at 564-65.

${ }^{128} I d$. at 568 ("Even if they did not use the term 'heightened,' courts still attempted to accomplish the same result by different means. The method of choice was the prohibition against 'conclusory' allegations, especially in civil rights cases.").

${ }^{129}$ Steinman, supra note 63, at 1308 ("The need to define 'conclusory' in the post-Iqbal era forces courts to confront the crucial question: what, exactly, must a complaint contain in order for a particular allegation to be accepted as true?").

${ }^{130}$ Brown, supra note 72, at 1286.

${ }^{131}$ Ashcroft v. Iqbal, 556 U.S. 662, 678.

${ }^{132} I d$.

${ }^{133} I d$. at 679. 
statements that plead "[im]plausible claim[s] for relief," 134 the "mere possibility" of a wrong, ${ }^{135}$ mere allegations of "entitle[ment] to relief," 136 or an "[un]shown ... entitle[ment] to relief." "137 Some other definitional guidance emerges when the court claims that "conclusory" can also mean that the statements in a pleading are "bare assertions" 138 or they are "formulaic recitation[s] of the elements" of a legal wrong. ${ }^{139}$ The last critical section from the opinion tells us a bit more about what "conclusory" means along with what it does not mean, where the Court indicates that "conclusory" does mean mere "bald allegations" but it does not mean that it involves value judgments or a determination of whether the complaint is "chimerical" or "extravagantly fanciful." 140 Not all chimerical and fanciful allegations are necessarily conclusory allegations and vice versa. Finally, drawing from the opinion, "conclusory" means a statement of conclusion "without reference to its factual context," but it does not simply mean "general." "141 One can have a general allegation and survive so long as it is not both general and conclusory. Not all general allegations are conclusory allegations and vice versa.

The confusion over "conclusory" is further fueled in part by the Court's seeming continued acceptance of the Form 11 pleading example in the Federal Rules of Civil Procedure, ${ }^{142}$ despite the fact that it seems quite conclusory in its presentation of a satisfactory pleading of negligence. ${ }^{143}$ The Court does not give a

\footnotetext{
${ }^{134} I d$.

${ }^{135} \mathrm{Id}$.

${ }^{136} I d$.

${ }^{137} I d$.

${ }^{138}$ Id. at 681.

${ }^{139} \mathrm{Id}$.

${ }^{140} \mathrm{Id}$.

${ }^{141} \mathrm{Id}$. at 688.

${ }^{142} I d$. at 677-78, 684-86.

${ }^{143}$ See Hatamyar, supra note 66, at 566 ("As another example of the conclusory facts dilemma, Justice Stevens and other scholars have pointed out that the judicial refusal to credit a 'conclusory' allegation as true on a 12(b)(6) motion is seemingly inconsistent with the conclusory nature of the official forms following the FRCP ...."). See also, e.g., Brown, supra note 72, at 1300 (discussing forms issue); Clermont \& Yeazell, supra note 61, at 824-25 (discussing inconsistency with sufficiency of Form 11); Spencer, supra note 62, at 12 (discussing the difficulty of understanding Iqbal's "conclusory" test in light of Form 11). Clermont and Yeazell provide the following critique:
}

[T] he system of civil litigation created by the Federal Rules had always credited conclusory allegations. Anyone who read the Rules, the Appendix of 
While EFfuSiVE, “CONCLUSORY” IS STIL L E L U I IVE

\begin{tabular}{l|l}
$P$ A G E & 253
\end{tabular}

satisfactory explanation for the difference between Form 11, which is acceptable, and the allegations it deemed conclusory and therefore unacceptable in Iqbal.

Professor Hatamyar perhaps stated it best: "Citing only the nearincomprehensible case of Papasin v. Allain, the Court provided no workable clarification of what is and is not 'conclusory.' Indeed, the Court failed to acknowledge the definitional ambiguity of 'conclusory' that has plagued the profession for at least a century." 144 Bone explained that "Iqbal changes the pleading landscape. It adopts a two-pronged approach with a first prong that makes little sense. $" 145$ Regardless of one's position on the standard, Iqbal makes clear that what is or is not conclusory must be a key question in every inquiry on the pleadings, ${ }^{146}$ yet its words give little guidance as to how that question should be answered in any given case beyond terms of definition that are as equally vague as the term it seemingly attempts to define.

\section{B. Selected Scholarly Definitions of "Conclusory" in Light of Iqbal/Twombly}

The majority of academic analysis has focused on the plausibility prong of Iqbal, although a few critics have highlighted the difficulty in ascertaining the meaning of "conclusory" as the primary concern for the standard. The conclusory prong, as the first part of the Iqbal test, deserves particularized attention. This section summarizes some examples from the academic literature and debate on how "conclusory" is or should be defined.

Professor Hartnett proposes a test best described as a "step further back" approach to defining "conclusory." 147 Hartnett argues that the conclusory prohibition means that a pleader must present more than an element of a claim and must also allege the factual bases for a conclusion:

Forms, and the preceding fifty years of case law would have thought that a conclusory allegation sufficed .... [A]lmost all of the sample complaints in the Rules' Appendix of Forms consist of conclusory allegations.

Clermont \& Yeazell, supra note 61, at 836.

${ }^{144}$ Hatamyar, supra note 66 , at 580.

${ }^{145}$ Bone, supra note 73, at 885 . See also, e.g., Hatamyar, supra note 66 , at 580 (calling the conclusory allegation label "bankrupt[]").

${ }^{146}$ Brown, supra note 72, at 1287 ("So the question becomes: what is the difference between the allegations that the Court held conclusory and those allegations that the Court found well-pleaded?").

${ }^{147}$ Hartnett, supra note 72. 
U N I V E R S I T Y O F P I T T S B U R G H L A W R E V I E W

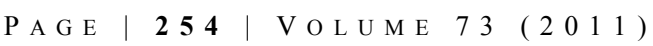

This approach suggests a way to understand what the Iqbal Court means by a "conclusory" allegation that is "not entitled to be assumed true." A conclusory allegation is one that asserts "the final and ultimate conclusion which the court is to make in deciding the case for him," that is, one that alleges an element of a claim. Such an allegation is not itself assumed to be true, but must be supported by the pleader going a "step further back" and alleging the basis from which this conclusion follows. ${ }^{148}$

Hartnett tracks the general, basic dictionary understanding of "conclusory" in this regard. ${ }^{149}$ Hartnett's approach, however, still leaves courts with the task of distinguishing between a conclusion and a basis, which, as seen in Iqbal itself, can be a difficult task.

Professors Clermont and Yeazell also propose a way to understand the meaning of "conclusory." 150 They acknowledge that "conclusoriness may be unclear and will be subjective" and that the test is a bit mysterious. ${ }^{151}$ Ultimately, the Court may be asking that the pleader at least give some factual insight into "actual" events and something more than mere "deductions of facts":

The first step of the new test presents its own mysteries. Conclusory allegations include a bare assertion that an element of the claim exists. But perhaps they include other "deductions of fact" statements, as opposed to more purely factual assertions. The likely bottom line is that the court should look mainly at what the plaintiff appears to be alleging actually happened (and then ask whether the elements of liability are a plausible inference from those allegations taken as true). Yet, even though conclusoriness may be unclear and will be subjective, deciding which allegations to ignore as conclusory will do much of the critical work. $^{152}$

Clermont and Yeazell do not seem to be contending that this is the only way one can interpret the requirement, but instead that it is one way in which it might be explained.

${ }^{148} I d$. (citations omitted).

${ }^{149}$ See infra Part IV.

${ }^{150}$ Clermont \& Yeazell, supra note 61.

${ }^{151} I d$. at 841 .

${ }^{152} I d$. 
Wh i L E EF F I I E, “CONCLUSORY” IS S T I L L E L U S IVE

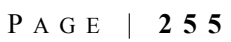

Professor Brown also offers a potential meaning for "conclusory" based on a two-part "sensory-perceptible" and "directly perceived" test. ${ }^{153}$ First, Brown asserts that "[a]n allegation in a complaint is 'conclusory' when the allegation attempts to plead directly an element of a claim that is only indirectly sensory-perceptible. By sensory perceptible, I mean capable of being perceived by any of the five senses." ${ }^{.154}$ Brown contends that this test is evident in the Iqbal decision. ${ }^{155}$ Second, a pleader must make clear that a directly sensory-perceptible claim was also "directly perceived":

Twombly, however, necessitates a second part of the definition of conclusory. An allegation in a complaint is also conclusory when the plaintiff pleads an element that is directly sensory perceptible, but pleads the element as though it has not been directly perceived .... The allegations of the "agreement" in Twombly were not describing some directly perceptible fact-instead they were reciting the element of the cause of action, and were pleaded as only indirectly perceptible .... ${ }^{156}$

Under Brown's test, the personalization of the allegation and inclusion of words indicating specific actual knowledge obtained through one's own perceptions could be enough to allow an allegation to escape disregard. ${ }^{157}$ Brown also agrees with Steinman that so long as one satisfies the requirement that allegations be nonconclusory, then there is no further required inquiry, "for a cause of action where all the elements are directly perceptible and the plaintiff directly pleads each element with sensory perceptible allegations, a court need not and cannot engage in the plausibility inquiry." 158

${ }^{153}$ Brown, supra note 72.

${ }^{154}$ Id. at 1288 .

${ }^{155}$ Id. at 1289 ("This definition of conclusory described above can be seen in Iqbal."); id. at 1292 ("I suggest also that the above definition of conclusory, although not compelled by, is nonetheless consistent with Supreme Court precedent before Twombly and Iqbal.").

${ }^{156}$ Id. at $1290-91$.

${ }^{157} I d$.

${ }^{158}$ Id. at 1292 ("As Professor Steinman has pointed out, in this situation the plausibility inquiry 'vanishes completely."'). 
Brown underscores that this test looks at alleging the perceptible, not the perceived. ${ }^{159}$ Thus, plaintiffs would not be required to "produce evidence to back up non-conclusory allegations in the complaint." 160 As such, Brown sees the requirement as adding relatively nothing more than the same level of compliance that would be required under Rule $11 .{ }^{161}$

Professor Robert Bone's analysis of Iqbal and Twombly looks at both the conclusory prong and the plausibility prong and emphasizes that the two-pronged approach adopted in Iqbal creates a demanding and confusing standard. ${ }^{162}$ Furthermore, its lack of clarity is troublesome and problematic with potentially dire consequences to plaintiffs. ${ }^{163}$ Bone begins by describing the Iqbal court as seeming to equate conclusory allegations with allegations stating legal conclusions, ${ }^{164}$ whether or not the plaintiff intended them to be so. ${ }^{165}$ However, Bone contends that that correlation is unconvincing: "The majority in Iqbal is extremely unclear as to why these allegations were legal conclusions."

${ }^{159} I d$. ("It is important to note that the definition of conclusory does not require sensory-perceived allegations, but instead sensory-perceptible allegations.").

${ }^{160} I d$.

${ }^{161}$ As Brown states:

Under Twombly and Iqbal, then, a Court is simply evaluating whether the plaintiff has adequately appraised her claim. The Court is not making any factual determination or weighing any credibility. The Court is not requiring a plaintiff to produce evidence to back up her well-pleaded allegations. Instead, the Court is determining whether the plaintiff's reasons for believing that she was discriminated against suggest that she will be entitled to relief. A plaintiff does not have a new evidentiary burden under Twombly and Iqbal. Instead, a plaintiff must reveal to the court what she is already required to have under Rule 11.

Id. at 1298 .

162 Bone, supra note 73, at 859 ("Iqbal's novel doctrinal contribution is to subdivide the pleading analysis formally into two prongs, with the first prong sorting legal conclusions from factual allegations ... The Iqbal Court breathes new life into the distinction and in so doing injects a highly problematic element into pleading analysis."). See also id. at 852 ("Iqbal's two-pronged approach obscures the fact that its pleading standard is stricter than Twombly's.").

${ }^{163} I d$. at 861 ("Lack of clarity about how to apply the first prong of the analysis is especially troubling because the classification of allegations as legal conclusions can be decisive.").

${ }^{164} \mathrm{Id}$. at 857.

${ }^{165}$ Id. at 859 ("In Iqbal, by contrast, the Court deems the key allegations to be legal conclusions not because the plaintiff intended them so-he clearly did not—but because they just were so.").

${ }^{166} I d$. 
While EFfuSiVE, “CONCLUSORY” IS STIL L E L U IVE

\begin{tabular}{l|ll}
$P$ A G E & 257
\end{tabular}

Bone contends that the court's real concern was whether allegations exhibit high degrees of generality. As he states, "[t]he adjectives 'unadorned,' 'threadbare' and 'conclusory' suggest a different problem; not that the allegations track formulaic language, but that they state facts at too high a level of generality." 167 Bone believes that the dissent believed this to be the meaning of "conclusory" applied by the majority, and that this interpretation created the dissent's area of principal disagreement: "Justice Souter's argument highlights a serious difficulty with the degree-of-generality approach to distinguishing conclusions from facts. There is no obvious way to draw a line along the generality-specificity continuum, and the Iqbal majority offers nothing to guide the analysis in a sensible way." 168 Thus, Bone concludes that "[c]ontrary to the arguments of some commentators, what qualifies an allegation as a 'legal conclusion' or as too 'conclusory' is not that it tracks the elements of a legal claim too closely. Rather it is that the allegation states facts at too high a level of generality."169

Bone summarizes what he believes the court means then by "conclusory" and then finds it wanting as a meaningful standard:

This means that allegations are too general-and thus qualify as "legal conclusions" or are too "conclusory"-when they fail to meet the pleading standard. But it is the complaint as a whole that must meet the standard, not each individual allegation taken separately .... The Twombly Court understood this point clearly .... It makes no sense first to exclude certain allegations as conclusory on account of their generality and then to subject the remaining allegations to the pleading standard. ${ }^{170}$

In this sense, Bone agrees with Souter's criticism in the Iqbal dissent.

${ }^{167}$ Id. at 860 .

${ }^{168} I d$. at 861 . Bone also claims that:

$[\mathrm{I}] \mathrm{t}$ is difficult to see the difference between this negligence allegation and the key allegations in Iqbal. The Form 11 allegation says nothing about what the defendant's car was doing before it hit the plaintiff or why the plaintiff believes the defendant drove negligently. If anything, the key Iqbal allegations seem more specific.

Id.

${ }^{169} I d$. at 868 .

${ }^{170}$ Id. at $868-69$. 
U N I V E R S I T Y O F P I T T S B U R G H L A W R E V I E W

P A G E

Finally, Bone posits one solution for litigators. He contends that, in order to avoid allegations being labeled conclusory, a litigant must move beyond information over which a plaintiff has a monopoly of private information:

[T]he reason why a judge applying a thick screening model would find the allegations in Iqbal and Twombly insufficient and classify them as conclusory is because the facts they allege are very likely to be the private information of the defendant, so the judge cannot be confident enough of trial success without more supporting detail... This interpretation of Iqbal explains why the Court demands greater specificity for the mental-state allegations in the complaint. Moreover, it provides a rigorous framework for understanding what seems obvious when reading the opinion, that the Court is more demanding than it was in Twombly. ${ }^{171}$

Bone's analysis is interesting and helps to describe a court's role as a gatekeeper. Of course, the level of additional detail that will be sufficient beyond such private information is still difficult for any litigant to predict. Bone exposes the fact that the conclusory inquiry likely applies to both legal and factual conclusions, but that does not dispose of the continued need to determine the meaning of "conclusory" itself and the threshold that a plaintiff must meet to satisfy the demand for nonconclusory allegations regardless of type.

Of the competing academic definitions for "conclusory" so far offered in the literature, Professor Adam Steinman's theory ${ }^{172}$ has perhaps received the most attention, ${ }^{173}$ largely because Steinman is seen not as describing what the Court means when it uses the word "conclusory" but instead what "conclusory" ought to mean. ${ }^{174}$ Steinman's prescriptive definition of "conclusory" arguably has some merit from a policy perspective, but it does not appear to have gained much traction in the lower courts. ${ }^{175}$

${ }^{171}$ Id. at $873-75$.

${ }^{172}$ Steinman, supra note 63.

${ }^{173}$ See, e.g., Brown, supra note 72, at 1288 (discussing Steinman); Eaton, supra note 65, at 316; Pardo, supra note 65, at 1495.

${ }^{174}$ Pardo, supra note 65, at 1495-96 ("Professor Steinman's reading of these cases is provocative and an important challenge to the 'conventional interpretation' of the pleading cases, but it does not stand up to close scrutiny.").

${ }^{175}$ Eaton, supra note 65, at 319 ("Professor Steinman's approach, despite being well-reasoned, is not wholly reflected in the case law that has emerged since Iqbal."). 
Steinman believes that Iqbal and Twombly can be read to preserve past pleading doctrine and that "the most significant pre-Twombly authorities are still good law." ${ }^{176} \mathrm{He}$ also contends that a proper interpretation of Iqbal means that, if all allegations are nonconclusory then plausibility review is unnecessary and indeed improper. ${ }^{177}$ This second claim is controversial and, although interesting, it tells us little about what "conclusory" means, and it is not critical to discuss the merits of this part of Steinman's analysis in this article.

Steinman starts with the proposition that "a pleading standard that allows courts to disregard conclusory allegations is not inherently a strict one. It depends on how 'conclusory' is defined." 178 In fact, he believes that Iqbal's demand for nonconclusory allegations is arguably consistent with notice pleading. ${ }^{179}$ Steinman rejects the contention that supporting evidence must be provided to satisfy the requirement that allegations are nonconclusory as fundamentally in conflict with the purposes of pleading standards, and the definition of "conclusory" applied in non-pleading contexts is not appropriate in terms of understanding the use of the word in pleading. ${ }^{180}$ This contention supports the conclusion that a focus on the generally accepted dictionary definition of "conclusory" is insufficient.

${ }^{176}$ Steinman, supra note 63, at 1298.

${ }^{177} I d$. ("[P]lausibility inquiry can be avoided entirely. As long as a complaint contains nonconclusory allegations for every element of a claim for relief, it passes muster regardless of whether the judge might label the allegations implausible. Plausibility comes into play only when an allegation necessary to the planitiff"s [sic] claim is disregarded as conclusory (or is missing entirely)."). See also id. at 1314 ("[T] he justifiably criticized 'plausibility' inquiry is not in fact the primary inquiry at the pleadings phase. Under Iqbal's two-step framework, the plausibility inquiry becomes irrelevant if a plaintiff provides nonconclusory allegations for each element of a claim for relief."); id. at 1316 (“[W]hen a complaint contains nonconclusory allegations on every element ... the plausibility issue vanishes completely."); Pardo, supra note 65, at 1495 ("According to Professor Steinman, the 'conventional wisdom' that Bell Atlantic and Iqbal impose a plausibility requirement is wrong as a descriptive matter. He contends that the problem with the complaints was that they were 'conclusory,' and that 'plausibility' may be a way to save a conclusory complaint but not a way to dismiss a non-conclusory complaint.”).

${ }^{178}$ Steinman, supra note 63, at 1324.

${ }^{179}$ Id. at 1324-25 (“Iqbal's recognition that conclusory allegations need not be accepted as true does not necessarily mean the end of notice pleading. It merely cloaks the notice inquiry in different doctrinal garb.").

${ }^{180} I d$. at 1328-29 ("Although courts in other contexts suggest that what makes an assertion 'conclusory' is a lack of supporting evidence, transplanting this attitude to the pleading phase would be problematic ...."). 
Steinman clearly believes that "conclusory" means something different from "evidentiary support." ${ }^{" 181}$ After all, Steinman claims, no allegation could meet such an "evidentiary support" test ${ }^{182}$ when the purpose of the pleading stage has never been to provide the actual evidence before trial.

Steinman's most relevant contribution to the "conclusory" definitional debate is his call for a "transactional" test to determine whether an allegation should be subject to disregard. ${ }^{183}$ Steinman states that "[o]ne way to reconcile Twombly and Iqbal with authoritative pre-Twombly texts and precedents is to define 'conclusory' in transactional terms. A plaintiff's complaint must provide an adequate transactional narrative, that is, an identification of the real-world acts or events underlying the plaintiff"s claim." 184 Steinman contends that "[w]hen an allegation fails to concretely identify what is alleged to have happened, that allegation is conclusory and need not be accepted as true at the pleadings phase." ${ }^{\prime 185}$ Pardo argues that Steinman's standard leads to no clearer explanation for the rejection of

${ }^{181} I d$. at 1329 ("If a court were to take seriously the idea that allegations may be disregarded because the complaint does not also provide evidentiary support for them, then supporting an allegation with more allegations will never be enough.").

${ }^{182} I d$. at 1351 ("If courts take seriously the idea that all allegations are conclusory when they are not bolstered by evidentiary support, then every allegation will be deemed conclusory, because any allegation offered to add additional support is merely another allegation.").

${ }^{183} \mathrm{Id}$. at 1334.

${ }^{184} I d$. Steinman explains his theory:

$[O]$ nly conclusoriness is a basis for refusing to accept the truth of an allegation; implausibility is not. The key question going forward, therefore, is how to assess whether an allegation may be disregarded as conclusory under the Iqbal framework. One answer is to define conclusory in transactional terms: an allegation is conclusory only when it fails to identify adequately the acts or events that entitle the plaintiff to relief from the defendant. What made the crucial allegations in Iqbal and Twombly impermissibly "conclusory" were legitimate (though certainly debatable) questions about whether those allegations were grounded in a series of real-world events. An allegation cannot, however, be deemed conclusory merely because the truth of that allegation is not suggested by some other allegation in the complaint.

Id. at 1298-99 (emphasis omitted).

${ }^{185}$ Id. at 1334 (emphasis omitted). Steinman also explains that, under his approach, "a complaint need not further explain how or why an event is alleged to have a particular quality or characteristic .... It is permissible to allege a characteristic of a transaction in conclusory terms, as long as the complaint identifies the core content of the transaction itself." Id. at 1341-42 (emphases omitted). 
certain claims in Twombly and Iqbal or a number of other satisfactory complaints that would fail the transactional standard. ${ }^{186}$

Steinman continues that "[a] corollary to the transactional approach proposed here is that an allegation may contain some language that, in isolation, might be characterized as conclusory without the allegation being deemed 'conclusory' for purposes of Iqbal step one." ${ }^{" 187}$ This explains why Form 11 can still be considered adequate and operative. ${ }^{188}$

To resolve some of the difficulties in understanding compliance with current standards, Steinman advocates a shift to a new pleading paradigm called "plain pleading" - a requirement that a statement include the identification of operative facts or events that are "free of "impediments to view" (or not "obscured by mere conclusory language") and that describe "tangible, real-world act[s] or event[s]" that "show that the pleader is entitled to relief." "189 A complaint meeting that standard should be sufficient to withstand a motion to dismiss, but "[i]f the plainly identified acts and events are insufficient by themselves (perhaps because some conclusory allegations were disregarded for lack of plainness), then Rule 8 is satisfied only if the plainly identified acts and events plausibly suggest an entitlement to relief.",190

Steinman acknowledges that the line between the "conclusory" and the "nonconclusory" may not always be clear, even under his test, but he finds that the degree of indefiniteness is to some extent unavoidable and such uncertainty is inherent in existing pleading standards as well. ${ }^{191}$ Furthermore, he posits that adopting a transactional approach to defining "conclusory" will provide an adequate check on judicial discretion. ${ }^{192}$

\footnotetext{
${ }^{186}$ Pardo, supra note 65, at 1495-96.

${ }^{187}$ Steinman, supra note 63 , at 1341.

${ }^{188} I d$. at $1341-42$.

${ }^{189}$ Id. at 1339 (emphasis omitted).

${ }^{190} I d$. at 1340 .

${ }^{191} I d$. at $1344-45$ ("The line between allegations that do and do not adequately identify the underlying acts or events may not always be clear. One could reasonably disagree with the Court's holdings that the crucial allegations in Twombly and Iqbal were conclusory. But uncertainty about how the federal pleading standard will apply to particular complaints is nothing new.").

${ }^{192} I d$. at $1346-47$ ("Basic principles, if faithfully observed, will provide a significant check on the ability of courts to overassert their power.").
} 
U N I V E R S I T Y O F P I T T S B U R G H L A W R E V I E W

PAGE

Steinman's plain pleading proposal is very attractive and worthy of further discussion. Because it is not the current operating standard, however, further discussion of the merits of the proposal will be tabled in this article.

Each of these interpretations is helpful but not sufficient. While each underscores that something more than a statement of conclusion is required after Iqbal, none gives any concrete measure by which a litigator can be confident he has gone far enough beyond the conclusion to meet the new minimum. After Iqbal, parties are left wanting for a definition of "conclusory." 193 The fact that no interpretation of the word's meaning posited to date can provide such confidence is, itself, evidence that there does not likely exist an interpretation capable of doing so. The absence of a comfort in any definition of "conclusory" suggests that argument by analogy may be the most workable method of persuasion available under such an indeterminate standard as that based on the word "conclusory." That method is the subject of Part V. Before getting there, it is necessary in Part IV to return to the tale of "conclusory" as a word, with particular emphasis on its dictionary definition. Part IV will dispose of the myth that the dictionary definition of "conclusory" can provide any meaningful aid to our understanding of Iqbal.

\section{IV. “CONCLUSORY” IN DICTIONARIES}

Whatever "conclusory" means, its meaning has become of supreme importance in civil litigation as a result of the decision in Iqbal. In interpreting Iqbal, it is intuitive and inevitable for lawyers, judges, and others seeking to understand the meaning of "conclusory" to turn to the dictionary. Comedian-writer Dave Barry once quipped, "If you have a big enough dictionary, just about everything is a word." For years (and somewhat still today) it seems the dictionaries were just not big enough to include the word "conclusory." But even if they were, dictionaries would not be enough to really understand what the word means in context in the Iqbal standard. This Part explores the battle between the word and the dictionaries to better understand whether and how dictionaries can help us understand the meaning of "conclusory" in judging the sufficiency of pleadings after Iqbal.

"Conclusory" has a storied tale when it comes to its recognition in dictionaries. With an inconsistent record of inclusion of the word "conclusory" in dictionaries, perhaps it is no wonder that lawyers are confused by how not to be conclusory. In the end, the word's story helps inform and support the conclusion

\footnotetext{
${ }^{193}$ Hatamyar, supra note 66, at 563 (describing the “'Conclusory' Conundrum”).
} 
that any reliance on dictionaries to provide lawyers with a useable understanding of the conclusory standard in Iqbal will leave them wanting.

Most lawyers and judges have come to regard and accept "conclusory" as a legitimate word. When lawyers are challenged that "conclusory is not a word," some of us react with the same recoil we might have had when we heard that Pluto is not a planet. ${ }^{194}$ While Pluto's plight was one of demotion, the struggle of "conclusory" has been one of promotion. Surprisingly, many people have mistakenly considered, and some continue to consider, "conclusory" as a nonword, or at best, some type of attorney slang. The problem, according to Garner in 1989 , is that "conclusory" has suffered as one of those "neologisms [that] abound in modern legal writing, though both writer and reader are often unaware that certain commonplace law words have yet to find a home in English dictionaries." 195 Absence from (i.e., non-inclusion in) a dictionary does not mean a word is absent from the language. ${ }^{196}$

Before the mid-1980s, it seems that all reference sources ignored the word "conclusory," at least in terms of recognizing it as a word with the meaning normally attached to it in the legal lexicon-some permutation of the broad concept of "a statement of conclusion without support." This lack of recognition and noninclusion in reference sources like dictionaries persisted despite the historical record of usage described in Part I of this article.

Even Black's Law Dictionary, long recognized as the leading law dictionary, ${ }^{197}$ did not include the word "conclusory" until its seventh edition in

${ }^{194}$ Denis Overbye, Vote Makes It Official: Pluto Isn 't What It Used to Be, N.Y. TimES, Aug. 25, 2006, at A13 (explaining the International Astronomical Union's decision to delist Pluto from the category of planets). The debate over the definition of planet and whether Pluto fits still wrangles today. See, e.g., Michael Byers, More Things in Heaven and Earth, N.Y. TIMES, Feb. 4, 2011, at A23 (In light of new information on the size of Eris, "some think it may be time to revisit Pluto's status. . . Pluto's demotion caused such an outcry because it altered something we thought we knew to be true about our world.").

${ }^{195}$ GARNER, Missing Words, supra note 13, at 343.

${ }^{196}$ Phillip A. Rubin, Note, War of the Words: How Courts Can Use Dictionaries in Accordance With Textualist Principles, 60 DuKE L.J. 167, 185 (2010) (“Although the absence of a particular word from a particular dictionary might tell the reader something, it does not indicate concretely that the word is not within the vocabulary of the language.") (emphasis omitted).

${ }^{197}$ See, e.g., Samuel A. Thumma \& Jeffrey L. Kirchmeier, The Lexicon Has Become a Fortress: The United States Supreme Court's Use of Dictionaries, 47 BufF. L. REv. 227, 241 (1999) (“Although there are other American law dictionaries, Black's Law Dictionary, and to a lesser extent Ballentine's Law Dictionary, are now the dominant American law dictionaries."); David Mellinkoff, The Myth of Precision and the Law Dictionary, 31 UCLA L. REV. 423, 434 (1983) ("Other law dictionaries have 
U N I V E R S I T Y O F P I T T S B U R G H L A W R E V I E W

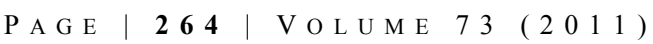

1999. ${ }^{198}$ Although "conclusory" has recently made its way into many other legal and common usage dictionaries as well, ${ }^{199}$ its universal inclusion in dictionaries is far from complete, and people still turn to old editions (on their shelves since law school, perhaps) or seek guidance from dictionaries where the word does not appear-fueling their uncertainty about the word's legitimacy. Rather than recognize the inherent limitations in a dictionary being used as a definitive source for determining the relative legitimacy of words, when a word is not found, "[ $t]$ he more frequent reaction is for the dictionary-user to conclude, with exaggerated deference to the dictionary-maker, that the use of such a word is incorrect."200

Whether correct or not, people's reactions to non-inclusion matter. As Garner notes, "the lexicographers' oversight has led to confusion among legal writers ...." "201 Similarly, its legitimacy has even evaded judges. In the past, the belief that "conclusory" is not a word has meant "[s]everal judges have actually tried to wage a minor battle against conclusory on grounds that it has no support in the dictionaries." 202

On the flip side, judges' mistaken beliefs that "conclusory" is included in dictionaries have also led to drastic, knee-jerk reactions against litigators who failed to use the word. For example, in 1987, a federal district court went so far as to begin drafting an opinion criticizing counsel for using (or what it believed to be "coin[ing]") the word "conclusionary."203 The court believed that "conclusionary" was not a legitimate term and believed that, surely, "conclusory" was the proper term that the lawyer should have used. ${ }^{204}$ But upon discovering neither "conclusionary" nor "conclusory" in the dictionary, the court reconsidered its rebuke. It stated, "This opinion was prepared to criticize Piscopos' counsel for use

been born. Many have died. Two law dictionaries took over the turf, and have kept it. They are Black's Law Dictionary and Ballentine's Law Dictionary.").

${ }^{198}$ BLACK's LAW DICTIONARY (7th ed. 1999).

199 See infra Part IV.C.

${ }^{200}$ GARNER, Missing Words, supra note 13, at 346.

${ }^{201} I d$.

202 Id. See also GARNER, ELEMENTS, supra note 13, at 38 ("[T] he useful word conclusory [is] much vilified by a few federal judges who seek its ouster from the legal lexicon ... [b]ecause it is nowhere in our modern dictionaries in the sense that lawyers commonly give it.").

${ }^{203}$ Consol. Capital Special Trust v. Am. Nat'l Bank \& Trust Co., No. 87 C 2818, 1987 WL 13995, at*1 n.2 (N.D. Ill. July 13, 1987). This example has not been documented in Garner's works.

${ }^{204} I d$. 
While EFfuSiVE, “CONCLUSORY” IS STIL L E L U IVE

of such a coined word as 'conclusionary' - but surprisingly, what this Court had regarded as its own proper usage ('conclusory') is not in Webster's Third New International Dictionary (unabridged ed. 1976) either." 205 The court was forced to dial back its frustration with the lawyer because it decided that the lawyer was justifiably ignorant of the fact that "conclusory" is a word.

Bryan Garner has done an excellent job describing the plight of "conclusory" and championing its quest for recognition. In at least ten published works (when you count multiple editions) since 1987, Garner has briefly described the battle to include "conclusory" in dictionaries and for its acceptance generally. ${ }^{206}$ Although none of Garner's works devoted more than a few pages to the word and its history, he nonetheless captured much of the history and many of the issues surrounding the relationship between "conclusory" and dictionaries. By 1987, he had exposed the non-inclusion of the word in most dictionaries and seemed to have made it a cause to help the word obtain legitimacy. This article later surveys Garner's work and, through supplemental information and analysis, provides the most comprehensive explanation of the word's story available to date. Research for this article confirms most of Garner's account and reveals several other interesting facts. Before turning to a summary of Garner's work on the word, it is enlightening to tell some stories about the confusion that the conflict between "conclusory" and the dictionaries has unleashed - some of which have been recognized by Garner, and many of which are told here for the first time.

\section{A. Further Stories from the Front Lines Grappling With Non- Inclusion}

In addition to anecdotal conversations with colleagues, research reveals a few public statements across the years about the frustration over dictionaries' treatment of the word "conclusory." A few of these deserve mention here to add color to the plight of the word.

Professor Peter Tiersma conveys an anecdote in a 2005 article otherwise generally discussing Garner's lexicographical philosophy. ${ }^{207}$ There he explains the consequences and casualties of non-inclusion of the word "conclusory" in dictionaries. On the failures of receipt of the dictionary imprimatur, Tiersma explains that he "once had a legal secretary who sent back my memos with

\footnotetext{
${ }^{205} I d$.

${ }^{206}$ See supra note 13 and accompanying text.

${ }^{207}$ See generally Peter Tiersma, Language Wars Truce Accepted (With Conditions), 8 GREEN BAG 2D $281(2005)$.
} 
comments such as 'conclusory is not an English word' ...."208 He wrote later that he discovered, "[i]nterestingly, the seventh edition of Black's provides a definition of conclusory (although my spell-checker keeps objecting as I write this)."209

I was surprised to find this quote when researching this essay because I was thinking the same thing about spell check, and that and other similar frustrations are what first piqued my own curiosity about the word's non-inclusion in dictionaries in the first place. Tiersma confirmed for me that mine was not an isolated case, and I expect many others have shared in this exercise of justifying our use of the term to others. My experience stemmed from using it in class and becoming impatient with students who did not know its meaning. After saying to them, "you should look it up," I decided one day to see what they would find if they followed my advice and turned to a dictionary. I was forced to return to class embarrassed to report that I now understood why some were confused. My command to look up the word seemed rather harsh in light of the fact that a definition was not readily and universally available. In the face of that, I was forced to rely on "trust me, it is a word" or "because I said so" as my authority when I then provided my understanding of the definition of "conclusory" to them. It was only after Iqbal that I decided to make a serious research inquiry into the where, when, and why it has been included or not included in dictionaries.

So, even years after Garner exposed the non-inclusion, lawyers and nonlawyers alike remained unaware of it. Another story comes from Mark Liberman, the Trustee Professor of Phonetics in the Department of Linguistics at the University of Pennsylvania, who took on the word "conclusory" in an April 2007 posting on the weblog Language $\log ^{210}$ In the post, he discusses his own difficulties in finding a dictionary definition for "conclusory" and focuses on both legal and non-legal uses of the word. Liberman's research into this seemingly foreign word was triggered after reading in a news story a quote from Senator Arlen Specter dismissing statements by Alberto Gonzalez as conclusory. ${ }^{211} \mathrm{He}$ wanted to understand what the word meant and its origins. Interestingly,

${ }^{208} I d$. at 286.

${ }^{209} I d$.

${ }^{210}$ See Mark Liberman, Conclusive = Good Conclusory = Bad, LANGUAGE LoG (Apr. 15, 2007), http://itre.cis.upenn.edu/ myl/languagelog/archives/004407.html. Liberman was apparently unaware of Garner's work through most of his research (which is not surprising since he is not a lawyer), and Garner was only acknowledged in passing after Liberman received a comment to the blog about his initial research.

${ }^{211} I d$. 
Liberman's independent research revealed a 1930 sub-headline in the New York Times that helps date the word: "Appellate Division Finds That Leon Bleecker's Answer Was Too Conclusory," ${ }^{, 12}$ reflecting that courts began to adopt the usage as early as 1930. From his research, Lieberman concluded that "[t]his semantic development seems to have started from a legal habit of complaining that a claim or argument is merely or only or excessively or (especially) too conclusory, in the sense of giving conclusions without providing adequate supporting evidence."213 He notes that the word has evolved across the years; modifiers like "mere" once seemed unnecessary, as the term itself assumed the sentiment of inadequacy. Lieberman states that "[o]ver time, the word conclusory alone, without 'too' or any other modifier, came to mean 'asserting conclusions without evidence.", 214

Professor Eugene Volokh discussed his own revelation about the general noninclusion of "conclusory" in dictionaries in a blog post on the Volokh Conspiracy weblog in May 2007, just after having given the legal definition to his class:

Huh? What do you mean, missing from standard English dictionaries? Well, sure enough, ... [s] [socking as it is to me-and to several lawyers that I talked tobut "conclusory," which I'd long assumed was a standard English term with the definition I just gave, is actually legalese. We lawyers are just so steeped in legalese that there's some legalese we no longer recognize as anything but normal. $^{215}$

Volokh's anecdote reveals that lawyers' presumptions about words common to them being included in the lay lexicon are often incorrect, and we must question whether some words like "conclusory" have a widespread, understood meaning beyond legalese. We also cannot depend on standard dictionaries to help define specialized terms.

\footnotetext{
${ }^{212} I d$.

${ }^{213} I d$.

${ }^{214} I d$.

${ }^{215}$ Eugene Volokh, Conclusory, THE VOLOKH CONSPIRACY (May 16, 2007, 1:41 PM), http://volokh .com/posts/1179272340.shtml (explaining that his revelation came after reading Mark Liberman's April 2007 Language Log entry on the matter). Volokh, surprisingly, makes no mention of Garner's work on the word in his rather short comment.
} 
Whether legal or lay, dictionaries have faults. While "our society's reverence for dictionaries is ... deeply embedded in our culture," ${ }^{216}$ we expect too much of them-perhaps because they do not capture specialized words and they sometimes lag behind even common usage.

That reverence has two consequences. First, we have come to believe in dictionaries so strongly that we dismiss words that cannot be found there. Second, we carry on with the use of a word we know is a word with a blind trust that, surely, it will be in the dictionary if anyone were to look. When we know it is a word, we simply know it must be in the dictionary. We tell ourselves that we must have looked it up at some point in our life, or we carry on never bothering to look it up, because it is so obviously a word from the fact that it has so regularly circulated in our own speech and that of our peers. Undoubtedly, many readers of this article are probably as surprised as I, Volokh, Liberman, and others have been to learn of this word's tortured struggle for lexicographical recognition.

Of course, then there are those who thought the word was new when it actually was not and consequently sought to "coin" it as one. As Garner reports, at least one state court felt a need to, in a published opinion, explain that "conclusory" was an acceptable word. ${ }^{217}$ In a 1987 opinion in Greenwood v. Wierdsma, Justice Walter Urbigkit on the Supreme Court of Wyoming stated that his court had "previously ruled that conclusory affidavits which do not contain facts to support the conclusions have little or no weight,", 18 and then held that "[w]hen stripped of their unsupported conclusions, the affidavits submitted on behalf of the hospital in no way assist the hospital's claim for summary judgment.... Without the conclusory paragraphs, the affidavits do nothing to controvert the assertions of the appellant's pleadings." ${ }^{219}$ In a footnote to that holding, the court felt a need to give the word "conclusory" its official seal of approval and encouraged its use, even if it distressingly seemed (as the court believed) to have been omitted from the English language:

\footnotetext{
${ }^{216}$ Lawrence Solan, When Judges Use the Dictionary, 68 AM. SPEECH 50, 50 (1993). See also Mersky, supra note 6, at 32 ("Though we may have our personal preferences or quibbles with a particular style or presentation used by individual lexicographers, it is often assumed that legal dictionaries are- for the most part—scholarly, precise, and authoritative.").

${ }^{217}$ GARNER, MOdERn Legal USAGE 3, supra note 13, at 192.

${ }^{218}$ Greenwood v. Wierdsma, 741 P.2d 1079, 1086 \& n.3 (Wyo. 1987).

${ }^{219} I d$.
} 
Wh i L E EF F I I E, “CONCLUSORY” IS S T I L L E L U S IVE

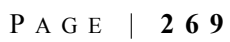

After painstaking deliberation, we have decided that we like the word "conclusory," and we are distressed by its omission from the English language. We now proclaim that henceforth conclusory is appropriately used in the opinions of this court. Furthermore, its usage is welcomed in briefs submitted for this court's review. Webster's, take heed! ${ }^{220}$

Although Garner and Block mention this case and discuss Justice Urbigkit's footnote, ${ }^{221}$ they do not report just how much attention was brought to the footnote in the press (or poetic commentary).

As it turns out, Urbigkit's footnote received a fair amount of popular attention. The ABA Journal put the pertinent excerpt of the Urbigkit opinion on their "Quotes" page in October 1987. ${ }^{222}$ Based on a wire service news story, several mainstream newspapers contemporaneously ran a feature item on the Urbigkit opinion, claiming the court was "lobbying" for a new word. ${ }^{223}$ These feature articles took a number of approaches to covering the word. Some speculated that "conclusory" must be a word combining conclusion and illusory. ${ }^{224}$ Other reports proclaimed that the word was "invented" by the judge's law clerk, including some that reported the judge had given his clerk that credit. ${ }^{225}$ In yet another story, one confused reporter did not understand the nuances of non-inclusion of "conclusory" in dictionaries and seemingly thought that a dictionary published years before the decision with the inapt definition of "conclusive" for "conclusory" meant

${ }^{220} I d$.

${ }^{221}$ See, e.g., GARNER, MOdERn Legal USAGE 3, supra note 13, at 192; Block, supra note 23.

${ }^{222}$ Quotes, A.B.A. J., Oct. 1, 1987, at 24.

${ }^{223}$ See, e.g., Wyoming Court Asks Webster's to Add a New Word, MiAmi Herald, Aug. 13, 1987, at 27A ("In an unusual display of judicial activism, the Wyoming Supreme Court is lobbying to have a new word officially included in the English language."); Court Lobbies for New Word, SouTH FLA. Sun-SENTINEL, Aug. 13, 1987, at 1A (generally quoting the footnote and Urbigkit's explanation of definition).

${ }^{224}$ Wordsmith, ORLANDO SEnTINEL, Aug. 14, 1987, at A17 ("Conclusory. The dictionary has missed that word .... His law clerk created what seems to be a combination of conclusion and illusory. Urbigkit's definition: 'The message is not justified by supported facts, which it assumes but doesn't state."').

${ }^{225}$ See, e.g., Judge Decludes: New Word is OK, SAN JoSE MerCury News, Aug. 12, 1987, at 1A (“The word appears to be a combination of 'conclusion' and 'illusory' ... . He said the word was invented by his law clerk, whom he described as a linguist of sorts."); A Proper Word in Court, N.Y. TIMES, Aug. 13, 1987, at A21 ("Judge Urbigkit said the word, and its Wyoming definition, was proposed by his law clerk, whom he described as a linguist of sorts."). 
dictionaries had already taken heed to include "conclusory." ${ }^{, 26}$ This loose coverage of a fun story obviously was not looking for precision in reporting or critical evaluation of the situation, and I presume Justice Urbigkit was equally loose with his words given the nature of the story. As the usage data in Part I illustrate, "conclusory" was not a new word at the time of the Urbigkit opinion and, consequently, the judge had not coined anything, despite the fact that some in the media and Urbigkit himself thought the opinion was revolutionary.

In fact, in another bit of trivia not previously reported in the legal discussions of "conclusory," Urbigkit's footnote even inspired a poem published in The Press of Atlantic City in 1987 (and just reprinted in a 2009 collection) criticizing what the poet thought was a horrifying new word. ${ }^{227}$ Who knew this little word that so many of us allowed to roll off our tongues could seem foreign to some and raise such attention or even satirical ire.

Outside of court, Urbigkit had a definition of his own to offer for "conclusory." "It means the message is not justified by supported facts, which it assumes but doesn't state, ${ }^{, 228}$ he explained to reporters. It appears that Urbigkit not

${ }^{226}$ See, e.g., A Proper Word in Court, supra note 225 ("Some Webster's had, in fact, already taken heed. Webster's New International Dictionary of the English Language, 2d edition, recognizes the word conclusory as an adjective meaning conclusive but notes that its use is rare.").

${ }^{227}$ A poem accompanying a news account of the Urbigkit footnote - together with a cartoon of a robed judge behind jail bars - appeared on an editorial page as far away as New Jersey just after the opinion. J.D. Evans, Throw the Book at Him, and Make It Unabridged, PreSS OF ATL. CiTY, Aug. 16, 1987, at A21 (article on file with author thanks to The Press archive department). The poet exclaimed:

It does our language injury [/] to use the word "conclusory." [/] Its meaning's not precise or clear. [/] What's more, it grates against the ear. [/] It muddles logic, tortures sense: [/] the opposite of eloquence. [/] Wyoming judges may be wise, [/] but when their rulings brutalize [/] the English language, it's a crime [/] (much worse than verse of doubtful rhyme). [/] "Conclusory" can't be allowed [/] to join a language justly proud [/] of its precision, wit, and grace. [/] A higher court must hear this case! [/] I'm sure a jury would agree: [/] We do not need "conclusory." [/] Judge Urbigkit should pay a price [/] for coining words that aren't concise. [/] His punishment should fit his crime. [/] We'll sentence him to spend some time [/] in jail or in a monastery [/] alone with just a ... dictionary.

Id. See also J.D. Evans, Occasionally: Collected Poems of J.D. Evans (1982-1987), at 217 (Jason Murk ed., 2009) (reprinting the poem without the cartoon or direct citation to the original placement).

${ }^{228}$ In Conclusion, Using “Conclusory” Not Illusory Move to U.S. Judge, GLOBE \& MAIL, Aug. 13, 1987, at A8 (internal quotation marks omitted) ("[The] word appears to be a combination of 'conclusion' and 'illusory.”') (reporting that Urbigkit stated that the word was created by his law clerk). 
only sincerely believed it was a new word; he even went so far as to defend the practice of creating words. As one newspaper reported:

\begin{abstract}
Although this apparently is the first time the state Supreme Court has come up with its own word to suit its needs, the justice says he would do it again. The English language needs to be made more specific, he insisted. "We need to have more defined, clearly expressed communicative skills," he said. The justice also pointed out that people are always devising words to suit their needs. "I think you (the news media) use them all the time, words that aren't words," he said. ${ }^{229}$
\end{abstract}

Urbigkit's belief in the novelty of his opinion reflects the over-reliance on dictionaries to test the legitimacy of vocabulary.

The fame (or infamy) of the opinion also led to its discussion in a clever little pop-culture dictionary published in 1998, on terms "that just pop out of the fabric of a family or a small group of people," called Family Words: The Dictionary for People Who Don't Know a Frone from a Brinkle, where "conclusory" is defined as an adjective used "when one makes an allegation that seems based on facts but is not." ${ }^{\text {230 }}$ A year after the Family Words publication, it finally made it into Black'sno causal relation or critique implied, of course, but an interesting progression and note of trivia, nonetheless.

Whether embracing the word despite non-inclusion or rejecting the word for non-inclusion, judges and lawyers have at least sometimes been confused by the word's history and unaware of the pattern of usage explained in Part I. More on the struggle for lexicographical recognition that has fueled the confusion follows in the next sections.

${ }^{229}$ Judge Decludes: New Word is OK, supra note 225. See also Ann Herold, From a Low Seat, Higher Math, L.A. TIMES, Aug. 14, 1987, at 2 (generally describing Urbigkit's position on the creation of words and reporting that the term was "coined by Urbigkit's law clerk").

${ }^{230}$ Paul Dickson, Family Words: The Dictionary for People Who Don’t Know a Frone from A BRINKLE 2, 33 (1998). The entry follows:

Conclusory. An adjective formed by the blend of conclusion and illusory and applicable, for instance, when one makes an allegation that seems based on facts but is not. What makes this term unusual is that it was a new word in a footnote to a court decision of the Wyoming Supreme Court by Justice Walter C. Urbigkit, Jr. . . .

Id. 
U N I V E R S I T Y O F P I T T S B U R G H L A W R E V I E W

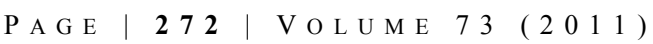

\section{B. Webster's 12,000 Words: The First Dictionary Inclusion of "Conclusory" Reflecting Its Modern Usage}

The stories above are emblematic of the relationship between "conclusory," dictionaries, and the legal community and outsiders-with difficulties that have lingered for years and continue to perplex many today. Urbigkit and those before him were partially correct. At the time of his opinion in 1987, "conclusory" was almost universally missing from any dictionary. But Urbigkit's claiming to have coined the word was in error on two fronts. First and foremost, inclusion of a word in a dictionary is not, and should not be, the only mark of the existence of a word. $^{231}$ There is an "aura of authority" that surrounds our perceptions of dictionaries $^{232}$ that is in part responsible for the belief that if a word is not in the dictionary, then it is not a word. ${ }^{233}$ We should not fall prey to such mistaken beliefs. As seen in Part I, "conclusory" had a history of usage and acceptance as a word expressing the idea of a conclusion without support for many decades prior to 1987. Second, and a point seemingly missed in all commentary on the word "conclusory" that has preceded this article, the first publication in a dictionary of the word "conclusory" with a definition matching its modern legal usage was arguably in $1986 .^{234}$

Despite the significant evidence of rather substantial and increasing usage of the word "conclusory" from around 1922 onward that is documented in Part I, it has taken many years for dictionaries to include the term, and many still do not. The first discovered publication of a definition of "conclusory" reflecting its modern legal usage was not until the 1986 addenda to Webster's Third titled 12,000 Words: A Supplement to Webster's Third New International Dictionary. ${ }^{235}$ After researching through various sequential editions of almost all major English language general usage and legal dictionaries for the purposes of this article, 12,000 Words appears to contain the first published dictionary definition of "conclusory" that matches its current usage in the legal lexicon-i.e., as meaning

\footnotetext{
${ }^{231}$ See infra Part IV.

${ }^{232}$ Rubin, supra note 196, at 167 ("Dictionaries have an aura of authority about them-words mean what the dictionary says they mean.").

${ }^{233}$ See infra Part IV.

${ }^{234}$ Indeed, according to a senior editor at Webster's, the Urbigkit quote is part of their files, but the opinion was published after the word and legal definition were included in the addenda to Webster's Third. See infra Appendix F.

${ }^{235}$ 12,000 Words: A SUPPLEMENT TO WebSTER's THIRD NEW INTERNATIONAL DictionARy 44 (1986) [hereinafter 12,000 WORDS].
} 
something more than, and different from, the rare and historic definition "conclusive." Rather than print new editions of Webster's Third, Merriam-Webster has followed the practice of occasionally publishing such addenda.

The entry in 12,000 Words defines "conclusory" "relating to, based on, or consisting of a conclusion," providing the usage example of "we agree plaintiff"s petition is [conclusory] and does not adequately state the factual basis for its assertion." ${ }^{236}$ This is an odd hybrid of the older definition with a usage example that incorporates the modern legal usage and meaning. As such, it is hard to say that this entry actually includes the key "lack of support" legal meaning within the definition. Interestingly, however, as translated into the definition adopted in the Merriam-Webster Collegiate Dictionary in 1993, the editors seemed to merge the usage component from 12,000 Words entry into the actual text of the definition. The Collegiate Tenth Edition entry for "conclusory" defines it as "consisting of or related to a conclusion or assertion for which no supporting evidence is offered," providing the usage example of "[conclusory] allegations.",237

In preparation for this article, letters requesting information about inclusion were sent to the editorial departments at most of the major dictionary publishers, including the publishers of Black's, Ballentine's, American Heritage, Oxford, and Merriam-Webster. ${ }^{238}$ Only Merriam-Webster and American Heritage replied, and part of their correspondence is included here as Appendices $\mathrm{F}^{239}$ and G. ${ }^{240}$

According to a senior editor at Merriam-Webster, in response to an official inquiry by this author, Webster's added their current definition of "conclusory" in 1986. ${ }^{241}$ As the Merriam Webster's editor explained, their files show inquiries from

\footnotetext{
${ }^{236}$ Id. (citing Lavergne v. W. Co. of N. Am., 371 So. 2d 807 (La. 1979)).

${ }^{237}$ Merriam-Webster's Collegiate Dictionary 239 (10th ed. 1993).

${ }^{238}$ The letter requested answers to the following questions: When and why did you first include the word "conclusory" in your dictionary? Upon what grounds were you motivated to include it? When and why did your entry for the word "conclusory" change, if at all? Are there any current plans to alter the entry for "conclusory" in forthcoming editions of your dictionary? Why is the word "conclusory" not listed as an entry in your dictionary? Have you ever considered listing "conclusory" in your dictionary and if so, when and why did you choose not to do so? Are there any current plans to add the word "conclusory" to your dictionary?

${ }^{239}$ See E-mail from Linda Wood, Senior Editor, Merriam-Webster, Inc., to author (Feb. 8, 2011, 11:33 EST) (attached as Appendix F).

${ }^{240}$ See E-mail from Steve Kleinedler, Executive Editor, American Heritage Dictionary, to author (Oct. 18, 2011, 09:15 EST) (attached as Appendix G).

${ }^{241}$ See id.
} 
lawyers starting in the early 1980s asking why "conclusory" was not included in their dictionaries. ${ }^{242}$ In response to the those inquiries, "[ $\left.\mathrm{t}\right]$ he reason given was that we had no evidence of the word being used by anyone other than lawyers (as was indeed the case) and that the word was considered too technical to be included in a general language dictionary." 243 Only after more letters arrived with citations to actual usage of "conclusory," was it, according to the editor, "decided that 'conclusory' would be added to our Addenda section of Webster's Third New International Dictionary, which was published in 1986."244 The editor found "no notes in the file explaining how or why this decision was made," but she did "assume that the editors felt that the correspondence we received showed that experts in the field considered this an important word, and that we had collected by this time enough citations to merit its entry." ${ }^{245}$ After receiving this letter, I discovered that the addenda to which she referred was 12,000 Words, a fact confirmed in follow-up correspondence with the editor. ${ }^{246}$

The editor's response to my inquiry concluded by explaining that the decision to include "conclusory" in 12,000 Words likely precipitated its being added to the 1993 publication of Merriam-Webster's Collegiate Dictionary, Tenth Edition-a codification-type process often followed for their addenda words-along with its being included in the 1995 publication of the first edition of Merriam-Webster's Dictionary of Law - the only two other dictionaries published by Merriam-Webster that include the word. ${ }^{247}$

\footnotetext{
${ }^{242}$ See id.

${ }^{243} I d$.

${ }^{244} I d$.

${ }^{245} I d$.

${ }^{246}$ According to the same senior editor at Merriam-Webster in a separate email, the definition was added to the manuscript pages of the draft for the addenda to 12,000 Words on April 22, 1985. See E-Mail from Linda Wood, Senior Editor, Merriam-Webster, Inc., to author (Feb. 15, 2011, 11:35 EST) (on file with author).

${ }^{247}$ The editor wrote in concluding her correspondence:

In 1993, Merriam-Webster's Collegiate Dictionary, Tenth Edition was published, and it included "conclusory" as an entry. Again, there are no notes in the file as to why the word was entered. But it was not unusual for words to first appear in the Addenda and to be subsequently added to the next Collegiate, and I assume that was the case with "conclusory." Since "conclusory" is limited in use to the legal field, it has not been added to our other dictionaries, which tend to exclude technical language. You will find it in Merriam-Webster's Dictionary of Law. The definition has not changed since its original entry.
} 
While EFfuSiVE, “CONCLUSORY” IS STIL L E L U IVE

\begin{tabular}{l|l}
$P$ A G E & $\mathbf{2} 7 \mathbf{5}$
\end{tabular}

Now, admittedly, the addenda are an odd way to add a word. Some might say that technically 12,000 Words is not a "dictionary." One can certainly argue that the addenda are not readily available and not an intuitive source that the average user of a dictionary would normally check it for a definition. Instead, most dictionary users would likely presume that a word they are searching would be included in that big book that labels itself "unabridged." Then again, legal researchers are always told to "Shepardize" and to "check the pocket parts," but it is not surprising that one would not immediately think that such a rule applies to dictionaries too. Perhaps the story of "conclusory" can teach us a lesson in that regard. Second, it should be acknowledged that the 12,000 Words definition of "conclusory" was a bit noncommittal-the distinguishing characteristic of modern legal usage was obscured by its inclusion in the example rather than being directly stated in the definition itself.

The general history of dictionaries and this enlightening letter from MerriamWebster provide important insights into the limitations of dictionaries. ${ }^{248}$ The next sections continue to discuss these issues.

\section{Garner at the Lexicographical Forefront for Defining "Conclusory"}

The first known published attempt to describe the significance of the word "conclusory" to legal practice was by lexicographer and legal writing expert Bryan Garner in his first edition of $A$ Dictionary of Modern Legal Usage in $1987 .{ }^{249}$ In recommending legal writing books to lawyers in a 1996 bar journal article, Thomas R. Haggard, a professor of law at the University of South Carolina, directed his readers to Garner's Modern Legal Usage stating that "[n]o serious legal writer should be without this book. Where else, for example, would you find justification for that most useful of legal words, conclusory?",250

See infra Appendix F.

${ }^{248}$ See Ellen P. Aprill, The Law of the Word: Dictionary Shopping in the Supreme Court, 30 ARIZ. ST. L.J. 275, 335 (1998) (“'It is] illuminating and useful to understand how Webster's dictionary is produced. Having done so, we realize that dictionaries are less comprehensive and authoritative than we previously thought.").

249 Garner, Modern Legal Usage, supra note 13. For a representative review, see Recent Publication: A Dictionary of Modern Legal Usage, 101 HARV. L. REV. 725 (1988) ("Mr. Garner . . . sets forth an authoritative guide to American legal usage and style. All legal writers will find it an invaluable help; many law review editors will find it a source of delight. Don't confront your editor without it.").

${ }^{250}$ Thomas R. Haagard, Books for the Lawyer-Writer, 8 S.C. LAW. 13 (1996). For examples of other reviews, see Laura Mansnerus, Lawyer Talk? You Can Look It Up, N.Y. TIMES, Dec. 11, 1987, at B8 ("Mr. Garner is more accommodating in spots, especially with neologisms that do for lawyers what no 
In the first edition of Modern Legal Usage in 1987, Garner defined "conclusory" as "[e]xpressing a mere conclusion of fact without stating the specific facts upon which the conclusion is based." 251 In the second edition of Modern Legal Usage in 1995, Garner changed his definition slightly to "expressing a factual inference without expressing the fundamental facts upon which the inference is based" 252 and stated additionally that "[ $\mathrm{t}]$ he word often describes evidence that is not specific enough to be competent to prove what it addresses.",253 Garner retained that definition (and the remainder of the entry on "conclusory") in the third edition released in the summer of $2011 .^{254}$

At the time of Garner's first and second editions of Modern Legal Usage, “conclusory" was not yet an entry in Black's Law Dictionary or Ballentine's Legal Dictionary and it was absent in most other legal or general usage dictionaries. Garner traced the origins of the word's usage to an opinion in the 1923 New York Appellate Division case of Ringler v. Jetter, ${ }^{255}$ as discussed in Part I.

In 1987, Garner stated that " $[n] o$ English dictionary lists conclusory as a main entry," and he singled out the Oxford English Dictionary as including it but only as a variant of "conclusive." $" 256$ In 1995 and again in 2011, Garner reworded his entry to say, "Most general English dictionaries fail to list conclusory as a main entry; the few that do misdefine it." 257 Garner explained that this defied understanding, as the word was clearly "widespread",258 and prevalent in the lexical exercises of legal

other words do. "Conclusory[,]" ... which some lawyer purists and nearly all dictionaries resist, is deemed all right, even useful."); Joel Chineson, Lone Star State Linguistics, Legal TimES, Nov. 28, 1988, at 30 ("Other standard references fail to list many usages common in legal speech and writing.").

${ }^{251}$ Garner, Modern Legal Usage, supra note 13, at 135.

${ }^{252}$ GARNER, MOdERn Legal USAGE 2, supra note 13, at 191.

${ }^{253}$ Id. See also GARner, Modern Legal USAGE, supra note 13, at 135.

${ }^{254}$ GARnER, Modern Legal UsAge 3, supra note 13, at 192.

${ }^{255}$ GARnER, Modern Legal USAGe 2, supra note 13, at 191.

${ }^{256}$ GARNER, Modern Legal UsAge, supra note 13, at 135 (emphasis added).

${ }^{257}$ Garner, Modern Legal Usage 2, supra note 13, at 191 (emphasis added); Garner, Modern LEGAL USAGE 3, supra note 13, at 192 (emphasis added).

258 Garner, Modern Legal Usage 2, supra note 13, at 192; Garner, Modern Legal Usage 3, supra note 13, at 192. Garner further discusses some authors using "conclusional" or "conclusionary" to accomplish the same purpose for which "conclusory" has come to be used but explained that "in American law at least, conclusory has become so widespread that conclusional should be considered a mere NEEDLESS VARIANT" and that "conclusionary ... was experimented with for a time and still occasionally appears-but, it has lost the battle for supremacy and should be rejected." GARNER, 
writing. He also explained that its general absence from dictionaries likely stymied its even more widespread adoption, as cautious legal writers avoided the word because it could not be verified by definitive resort to the accepted authority that is a dictionary. ${ }^{259}$ In the second edition, he also added material not included in the first edition, including some usage statistics and the Urbigkit case quote, and criticized not just the Oxford English Dictionary but also Merriam-Webster for non-inclusion. ${ }^{260}$

Webster's 12,000 Words actually predated Garner's criticism in the first edition (although it is probably fair to say that they were nearly simultaneous, given publication and informational lags). By the second edition of Modern Legal Usage in 1995, however, Webster's inclusion of "conclusory" in 12,000 Words and Webster's Collegiate was discoverable, but not specifically mentioned by Garner. There have been many other critics of Webster's Third, generally, when it comes to the inclusion of legal words or the accuracy of legal definitions. ${ }^{261}$ But in this instance, Garner's critique of Merriam-Webster was only partially appropriate. It is true that, given the usage history of "conclusory," even 1986 seems late for a dictionary to recognize it as a word worthy of inclusion, but technically Webster's had recognized or corrected its oversight before Garner's initial 1987 criticism, which he then nonetheless repeated for years thereafter without giving any credit for the entry in 12,000 Words or specifically recognizing some other intervening developments.

Garner once again addressed the "conclusory" controversy and lexicographical conundrum in a 1989 essay titled "Novelties in Lawyer Talk," which appeared in The Appellate Advocate. ${ }^{262}$ Garner defined "conclusory" as "expressing a mere conclusion of fact without stating the specific facts upon which

Modern Legal Usage 2, supra note 13, at 192; GARner, Modern LeGAL Usage 3, supra note 13, at 192. For some perspective on the comparative usage of those three terms, see infra Appendix A.

259 Garner, Modern Legal Usage 2, supra note 13, at 191; Garner, Modern Legal Usage 3 , supra note 13, at 192 ("Still, despite its currency - its appearance in tens of thousands of published sources - its absence from dictionaries gives some legal writers pause.”).

${ }^{260}$ Garner, Modern Legal Usage 2, supra note 13, at 192; Garner, Modern Legal USAGE 3 , supra note 13 , at 192 .

${ }^{261}$ See, e.g., Mellinkoff, supra note 197, at 437-38 (“'[O]rdinary English language dictionaries are not dependable for the general sense of those words that are peculiar to the law .... [W] hen it comes to law, ... [i]n some instances, [Webster's Third] is plain wrong . . . In some instances, it is sloppy and misleading ...."’).

${ }^{262}$ GARNER, Novelties, supra note 13 , at 327. 
U N I V E R S I T Y O F P I T T S B U R G H L A W R E V I E W

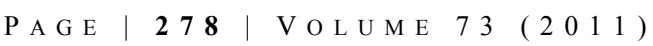

the conclusion is based." ${ }^{263}$ Garner again stated that, "[1]ike many other legal neologisms, [conclusory] is not recorded in any general English-language dictionary in its current legal sense. ${ }^{264}$ Of course, that broad statement is debatable, as Webster's had by this time certainly published the definition in 12,000 Words. As stated before, however, the sentiment about non-inclusion was otherwise valid and reflected the otherwise general inattention to the word in dictionaries.

That issue aside, the 1989 essay was really designed to focus on detailing the debates, conducted across a series of letters, between himself and Charles Allen Wright on one side and Robert E. Keeton on the other. ${ }^{265}$ That debate was over whether "conclusory" should be a recognized and encouraged word and whether, if there needs to be a word to capture the concepts of unsupported conclusions, the word "conclusionary" or the word "conclusional" was a better choice. ${ }^{266}$

In 1988, Judge Robert E. Keeton wrote Garner, saying he wished he could persuade Garner to reconsider the position on "conclusory" he took in Modern Legal Usage, Keeton himself preferring "conclusional" as the word to express the sense of meaning that Garner ascribed to "conclusory."267 Professor Charles Allan Wright was copied on that correspondence and sided with Garner in a letter response, citing the fact that more than 21,000 cases had used the word "conclusory." 268 Garner also replied to Keeton that "conclusory" was a better choice, as it had a record of usage that "conclusional" could not compete with. ${ }^{269}$ The debate continued after Keeton noted that Justice Ruth Bader Ginsburg had recently used the word "conclusionary" to capture this concept in need of a name. ${ }^{270}$ Garner and Wright responded in kind, and Garner's defense of the word "conclusory" in a letter to Keeton is substantially reprinted as part of Garner's 1989 essay. $^{271}$

\footnotetext{
${ }^{263} I d$.

${ }^{264} I d$. (emphasis added).

${ }^{265} \mathrm{Id}$. at $327-32$.

${ }^{266} I d$.

${ }^{267}$ Id. at 328 .

${ }^{268} \mathrm{Id}$.

${ }^{269} I d$. at 329.

${ }^{270} \mathrm{Id}$.

${ }^{271}$ Id. at $330-31$.
} 
While EFfuSiVE, “CONCLUSORY” IS STIL L E L U IVE

\begin{tabular}{l|r|r}
$P$ A G E & 279
\end{tabular}

The debate summarized in the 1989 essay was not over whether there should be a word to capture the concept nor was it over the meaning or concept for which a word needed to be chosen. It was just a debate over which of three alternatives"conclusory," "conclusionary," or "conclusional"-was preferable. The appropriate choice between the three is beyond the scope of this article, although the independent research conducted for the purposes of this article and the findings reported in Appendix A lend support to Garner's claim that "conclusory" has a more substantial record of usage. ${ }^{272}$

Again in 1990, in an essay titled "The Missing Common Law Words" published in a book called The State of the Language, Garner dealt with "conclusory" in his analysis collecting words that, "despite their indisputable currency in law, remain nonwords in the pages of our most highly touted reference works." 273 There, he defined "conclusory" as "[e]xpressing a mere conclusion of fact or a factual inference without stating the underlying facts on which the conclusion or inference is based. ${ }^{274}$ Garner noted his continued frustration over the word's non-inclusion in dictionaries, singling out for criticism the Oxford English Dictionary, ${ }^{275}$ Webster's, ${ }^{276}$ and Random House.${ }^{277}$ He also stated that "[m]ost law dictionaries are equally unavailing; the word appears in no law dictionary other than my own Dictionary of Modern Legal Usage." ${ }^{278}$ Research for this article confirms all of these statements were as true as of 1990, except for the failure, again, to acknowledge Webster's 12,000 Words, instead stating that "Webster's Third leaves it out altogether."279

Garner's definition in the 1991 publication The Elements of Legal Style again noted that "conclusory" was indeed a "useful word," despite some believing it was not, and defined it as "expressing a factual inference without expressing the facts

${ }^{272}$ See infra Appendix A. See also supra Part I.

${ }^{273}$ GARNER, Missing Words, supra note 13, at 344-45.

${ }^{274} \mathrm{Id}$. at 345 .

${ }^{275} \mathrm{Id}$. at 345 ("Conclusory . . . is ... in the OED really as nothing but a needless variant of conclusive ... [with] no hint ... of the modern legal sense.”).

${ }^{276}$ Id. (“Webster's Second lists it as 'rare' for conclusive, and Webster's Third leaves it out altogether.").

${ }^{277} I d$. ("The first edition of the Random House omitted it; the second edition revived it as a main entry ... but they misdefined it by following the $O E D$ and giving conclusive as its synonym.")

${ }^{278} I d$.

${ }^{279} I d$. 
U N I V E R S I T Y O F P I T T S B U R G H L A W R E V I E W

PAGE

on which the inference is based." ${ }^{280}$ Garner added there that "[b]ecause it is far more common in legal writing than its variants, conclusional and conclusionary, it is preferable to them.",281

Garner published another new reference book in 1998, titled Garner's Modern American Usage, where his definition for "conclusory" was "expressing a factual inference without stating the fundamental facts on which the inference is based," providing the usage example of "conclusory allegations." $282 \mathrm{He}$ also explained that "conclusional" and "conclusionary" are "NEEDLESS VARIANTS of conclusory." 283 The second edition, in 2003, changed the definition slightly and explained that "conclusory" means "expressing a factual inference without stating the facts or reasoning on which the inference is based," again providing the usage example of "conclusory allegations." 284 This definition was retained in the third edition of Modern American Usage published in 2009. ${ }^{285}$

Shortly thereafter, in 1999, the seventh edition of Black's Law Dictionary was published - the first edition under Garner's leadership as editor-in-chief - and it included an entry and definition for "conclusory" for the first time in that publication's history. ${ }^{286}$ The influence of Garner's previous work regarding "conclusory" is evident in the recent editions of Black's. As previously stated, the Black's definition is that "conclusory" is an adjective meaning "[e]xpressing a factual inference without stating the underlying facts on which the inference is based," providing the usage example of "because the plaintiff's allegations lacked any specific evidence they were merely conclusory."287 The eighth and ninth editions of Black's have retained that definition and explanatory usage example. ${ }^{288}$

The most recent original definition provided by Garner was in his first edition of The Redbook: A Manual on Legal Style in 2002. ${ }^{289}$ In The Redbook, Garner gave

\footnotetext{
${ }^{280}$ GARNER, ELEMENTS, supra note 13, at 107.

${ }^{281} I d$.

${ }^{282}$ Garner, Modern Legal Usage, supra note 13, at 146.

${ }^{283} \mathrm{Id}$.

${ }^{284}$ GARNER, Modern AmericAn USAge 2, supra note 13, at 174.

${ }^{285}$ Id. at 178 .

${ }^{286}$ BLACK's LAW Dictionary (7th ed. 1999).

${ }^{287} \mathrm{Id}$.

${ }^{288}$ Id. (8th ed. 2004); id. (9th ed. 2009).

${ }^{289}$ GARNER, REDBOOK, supra note 13, at 195.
} 
his broadest and most general definition of "conclusory" yet, seemingly adaptable to circumstances outside of pleadings and even outside of law- "a statement that puts forth a conclusion but not the reasoning behind it." ${ }^{290} \mathrm{He}$ also weaved in commentary and an example of the difference between "conclusory" and "conclusive" with his statement that "[t]he appearance of conclusory in tens of thousands of legal opinions is conclusive proof that the word does in fact exist, despite its absence from many dictionaries." ${ }^{291}$ The definition and those statements were retained in the second edition of The Redbook published in $2006 .{ }^{292}$

An interesting sidebar from the focus on Garner's research is the work of the one other academic who has published remarks about the word "conclusory" and its relationship with dictionaries. Professor Gertrude Block published her answers to queries on the proper use of the word "conclusory" in several venues, including two state bar journals in 1997 and $1999^{293}$ and in her 2004 book, Legal Writing Advice: Questions and Answers. ${ }^{294}$ Her analysis largely tracked the information reported in Garner's first edition of Modern Legal Usage and caused her to comment, among other things, that "[a]pparently the editors of the OED do not read court opinions or law-review articles." ${ }^{, 295}$ Block's 1997 and 1999 publications appear to rely on Garner's representations (although not explicitly cited) in his 1987 edition and do not take note of the developments of inclusion in several dictionaries since 1986. Block's 2004 book mentions checking Webster's Third 1996 edition and the American Heritage Dictionary's 2000 edition for evidence that those dictionaries do not include the word. It should be noted that Webster's Third does not add its addenda to the full dictionary when it is subsequently reproduced in later years, so while the reference may have been dated 1996, it would not have included any new words since its original date of publication. Hence, it would not have listed "conclusory" despite the prior addenda. By 2004, the third and fourth editions of the American Heritage Dictionary included a

\footnotetext{
${ }^{290} I d$.

${ }^{291} I d$.

${ }^{292}$ GARNER, REDBOOK, supra note 13 , at 226.

${ }^{293}$ Block, supra note 23, at 53 (" $[\mathrm{A}]$ search of both law and lay dictionaries revealed a surprising fact: Neither conclusory nor conclusionary is listed in Ballentine's Law Dictionary (Third Edition), Black's Law Dictionary (Fifth Edition), Words and Phrases, The American Heritage Dictionary (Second College Edition), or Webster's New Third International Dictionary (Unabridged) ...."); Gertrude Block, Language Tips, 69 N.Y. ST. B.J. 48 (1997) (same).

${ }^{294}$ Gertrude Block, Legal Writing Advice: Questions AND ANSWers $84-85$ (2004).

${ }^{295} I d$.
} 
definition of "conclusory." ${ }^{296}$ Nonetheless, Block's 2004 book mentions nothing of the other dictionaries that did, by that point, include "conclusory," such as Webster's Collegiate, Merriam-Webster's Dictionary of Law, or Black's Law Dictionary. ${ }^{297}$ In Block's defense, however, the 2004 book appears to be only a compilation of past advice gathered together for that book, which she had given well before 2004, and it also was not intended as a reference source, but instead was designed as a legal writing book for which the accuracy of the lexicographical commentary was not critical.

Finally, a 2009 collection of Garner's works called Garner on Language and Writing included the following original and new notation to the reprinting of the "Novelties" essay from 1989: "Since the first publication of [Novelties] in 1989, most American dictionaries have added conclusory." ${ }^{298}$ Research for this article confirms that that statement is generally accurate. The next section collects some of the current definitions in dictionaries, accompanied by some explanation of additional history preceding each inclusion.

\section{Inclusion and Non-Inclusion: A Closer Look at Specific Dictionaries}

Garner contends that lexicographers have not purposefully omitted "conclusory," but instead "overlooked much of the linguistic innovation in law.",299 Over the past two decades, many, but not all, dictionaries have recognized their oversight. This section collects many of the major general and legal dictionaries from major publishers to survey the available definitions. Garner's definitions are not listed in this subsection, as they are focused on elsewhere in this article.

Webster's dictionaries have the broadest definitions, and they are probably the most useful starting point of analysis. Until 1986, Webster's dictionaries either did not include "conclusory" at all or listed it to mean only "conclusive." As stated previously, Webster's was the first of all the dictionaries to include an entry for "conclusory" with a definition appropriate to its legal usage in 12,000 Words, although it had its flaws. ${ }^{300}$ Webster's Collegiate Dictionary first listed "conclusory" as a separate entry in its 1993 edition as "Law asserted as a

\footnotetext{
${ }^{296}$ See infra Part IV.D.

${ }^{297} \mathrm{Id}$.

${ }^{298}$ GARNER, Novelties, supra note 13, at 327 n.1.

${ }^{299}$ GARNER, Missing Words, supra note 13, at 346-47.

${ }^{300}$ See supra Part IV.B.
} 
While EFfuSiVE, “CONCLUSORY” IS STIL L E L U IVE

\begin{tabular}{l|lll}
$P$ A G E & 283
\end{tabular}

conclusion without supporting facts." ${ }^{301}$ Webster's New World College Dictionary first listed "conclusory" as a separate entry in its fourth edition in 1999 with the same definition as the Collegiate version, and that definition remains in its most recent edition. ${ }^{302}$

The American Heritage Dictionary added "conclusory" to its third edition published in $1992 .{ }^{303}$ It first defines it as "conclusive" and then as "Law convincing, but not so much so that contradiction is impossible; not justified or supported by all the facts: 'Perfunctory and conclusory findings of the magistrate ... did not comport with requirements of Federal Rules of Civil Procedure' (National Law Journal)." ${ }^{\prime 304}$ This is a far more forgiving definition of the word than most of the other available dictionary definitions, which give it a much more negative meaning. The inclusion of the word "convincing" in the 1992 American Heritage definition seems to be quite contrary to the normal usage of the word in law. The 1999 Encarta World English Dictionary has the same type of entry, with an equally forgiving definition, rather inconsistent from the majority of definitions and usages; it defines "conclusory" as "LAW convincing but not to extent it cannot be contradicted." ${ }^{\prime 305}$ As discussed above, and the Oxford English Dictionary still defines "conclusory" as only "conclusive." 306

Recognizing the flaws in its original, 1992 definition of conclusory, the American Heritage Dictionary published a new, partial replacement definition in its fifth edition released in November 2011. ${ }^{307}$ The new entry retains the first definition of "conclusive" and the second definition is "Law. Relating to or being a conclusion of fact presented without the statement of specific supporting evidence upon which the conclusion is based: conclusory findings. ${ }^{308}$ In an October 18, 2011 letter to this Author responding to the inquiry about the history of entries for "conclusory" in the American Heritage Dictionary or other Houghton Mifflin Harcourt dictionaries, Executive Editor Steve Kleinedler explained the American

\footnotetext{
${ }^{301}$ WeBster's COlLEGiate Dictionary (10th ed. 1993).

302 Webster's New World College Dictionary 302 (4th ed. 1999). See also WeBSTER's NeW WORLD COLLEGE DiCTIONARY 289 (3d ed. 1997) (no entry).

303 American Heritage Dictionary of the English Language 392 (3d ed. 1992).

${ }^{304} I d$.

${ }^{305}$ ENCARTA WORLD ENGLISH DICTIONARY 377 (1999).

${ }^{306}$ OXFORD ENGLISH DICTIONARY (2d ed. 1989).

307 AMERICAN Heritage Dictionary of THE ENGLish LANGUAGe 382 (5th ed. 2011).

${ }^{308} I d$.
} 
U N I V E R S I T Y O F P I T T S B U R G H L A W R E V I E W

PAGE

Heritage Dictionary's change in definition by quoting its consultant's explanation for the new definition and the discarding of the old as follows:

The existing definition is wrong. The example given with the definition is making the point that naked factual findings, without more, aren't formally adequate for a magistrate's decision (as an appellate court would not be able to determine the basis for the conclusions of the magistrate and so would be dealing with an incomplete record). Calling something conclusory is not to call it wrong, but to call it incomplete or inadequate in format. It has nothing to do with being "convincing" or "not ... supported by all the facts." A lab technician stating that the defendant was the origin of a blood sample found at the scene of a crime would be presenting conclusory testimony; a lab technician presenting the comparison of the DNA profile of the defendant and that of the sample taken from the scene would be not be presenting conclusory testimony. ${ }^{309}$

The change brings the American Heritage Dictionary more in line with the traditional legal usage of the term and makes it more consistent with the other dictionaries that have now included the term. It is clear from this example, however, that even as of 2011, dictionary editors continue to grapple with not just the inclusion of the word but the appropriate definition, as well.

Merriam-Webster's Dictionary of Law added the term when it first published in 1996, including the term as a separate entry with the relevant accompanying definition reflective of legal usage. ${ }^{310}$ In it, "conclusory" is defined as "consisting of or relating to a conclusion or assertion for which no supporting evidence is offered," with the usage example of "conclusory allegations." 311 Random House Webster's Dictionary of the Law lists "conclusory" separately, with the definition of "stating a conclusion without supporting facts" and with the usage examples of "a conclusory allegation" and "a conclusory affidavit.", 112 As previously discussed, Black's Law Dictionary did not list "conclusory" in its first six editions, ${ }^{313}$ but it has listed "conclusory" since 1999 and provides the definition of "[e]xpressing a factual inference without stating the underlying facts on which the inference is

\footnotetext{
${ }^{309}$ E-mail from Steve Kleinedler, Executive Editor, American Heritage Dictionary, Houghton Mifflin Harcourt to Donald J. Kochan (Oct. 18, 2011, 9:15 a.m.) (attached as Appendix G).

${ }^{310}$ MerRiam-Webster's Dictionary of LAW 92 (1996).

${ }^{311} I d$.

${ }^{312}$ RANDOM House Webster’s Dictionary of THE LAW 96 (James E. Clapp ed., 2000).

${ }^{313}$ BLACK'S LAW DiCTIONARY (1st-6th eds.).
} 
based." 314 Other, rather new, legal dictionaries include entries for "conclusory" appropriately related to the general legal understanding. For example, Mellinkoff's Dictionary of American Legal Usage, in its first edition in 1992, included "conclusory" as "assuming a conclusion not supported by facts or the law," with a useful illustration. ${ }^{315}$ Oran's Dictionary of the Law has a similar definition for "conclusory": that which "[d]escribes an assertion that is not supported by facts. Not conclusive." 316 Words and Phrases now also includes entries for "conclusory" with usage examples from cases. ${ }^{317}$

Ballentine's Legal Dictionary and Thesaurus, its latest edition printed in 1995, has never listed "conclusory." 318 Burton's Legal Thesaurus lists "conclusory," but provides synonyms that reflect its older, non-legal usage, such as "conclusive (settled), decisive, definitive, final, last (final), ultimate." ${ }^{\prime 19}$ As a legal reference book, this seems to be an inexcusable oversight at this point in the historical development of the word and its recognition in so many other publications. "Conclusory" is also not listed in Barron's Dictionary of Legal Terms, as of its 2008 edition. ${ }^{320}$

Online dictionaries often include the word "conclusory," and the variance in the definitions is interesting, as searches retrieve mixed results for the consistency and accuracy of the definitions in relation to the modern usage of the term. Merriam-Webster Online tracks Webster's Collegiate Dictionary ${ }^{321}$ and defines

314 Black's Law Dictionary 329 (9th ed. 2009). See also Black's Law Dictionary 308 (8th ed. 2004) (same definition); BLACK's LAW Dictionary 329 (7th ed. 1999) (same definition).

315 Mellinkoff's Dictionary of American Legal Usage 102 (1992) (“(adj.): assuming a conclusion not supported by facts or the law. $<[1$.$] Your argument is that Jones was acting in good faith.$ But that's conclusory, counsel. What evidence supports that conclusion? [2.] You don't make her the defendant's agent simply by saying so; that's conclusory. Neither the evidence nor the law makes out a principal-agent relationship.>"). For a discussion of the need for a usage dictionary, see Mellinkoff, supra note 197, at 440 (discussing the merits of creating "A Dictionary of American Legal Usage").

316 Daniel Oran \& Mark Tosti, Oran’s Dictionary of THE LAW 104 (3d ed. 1999).

317 8A WORDS AND PHRASES 149-50 (Supp. 2011).

318 JONATHAN S. LyNTON, BALlentinE's LegAl DictionARy AND THESAURus (1995) (no entry). See also, e.g., BALLENTINE's LAW DictiONARY (3d ed. 1969) (no entry).

319 William C. Burton, Burton's Legal Thesaurus 684 (McGraw-Hill Cos. 4th ed. 2006) (emphasis omitted).

${ }^{320}$ STEVEN H. GifTS, BARRON's Dictionary OF LEGAL TERMS (4th ed. 2008).

${ }^{321}$ About Us, MERRIAM-WeBSTER, http://www.merriam-webster.com/info/faq.htm (last visited May 25, 2012). 
U N I V E R S I T Y O F P I T T S B U R G H L A W R E V I E W

PAGE

"conclusory" as "consisting of or relating to a conclusion or assertion for which no supporting evidence is offered," providing the usage example of "conclusory allegations." "322 Your Dictionary (which is used by Yahoo! ${ }^{323}$ for definitions, as well) defines "conclusory" as "1. Coming to a conclusion or decision; conclusive 2. LAW asserted as a conclusion without supporting facts. ${ }^{324}$ The Free Dictionary lists it as "1. Conclusive. 2. Law Convincing, but not so much so that contradiction is impossible; not justified or supported by all the facts: 'Perfunctory and conclusory findings of the magistrate ... did not comport with requirements of Federal Rules of Civil Procedure' (National Law Journal)," crediting the American Heritage Dictionary of the English Language, Fourth Edition, as its source. ${ }^{325}$ Dictionary.com lists three definitions: one as only "conclusive," crediting the Random House Dictionary as its source; another as "1846, "pertaining to a conclusion,' from conclusion. Probably coined because the secondary 'decisive' sense had come to predominate in conclusive," crediting the Online Etymology Dictionary; and a last entry as "consisting of or relating to a conclusion or assertion for which no supporting evidence is offered," providing the usage example of "conclusory allegations" and crediting the Merriam-Webster's Dictionary of Law, 1996 edition. ${ }^{326}$

FindLaw defines "conclusory" as "consisting of or relating to a conclusion or assertion for which no supporting evidence is offered [allegations]," citing Merriam-Webster's Dictionary of Law 1996 as its source. ${ }^{327}$ But a search for the word "conclusory" produces no results in the dictionaries at the websites for Law.com, ${ }^{328}$ Law Dictionary, ${ }^{329}$ and Nolo's Plain English Law Dictionary online. ${ }^{330}$

\footnotetext{
322 Conclusory, MERRIAM-WEBSTER, http://www.merriam-webster.com/dictionary/conclusory (last visited May 25, 2012).

${ }^{323}$ Conclusory, YAHOO! EdUCATION, http://education.yahoo.com/reference/dictionary/?s=conclusory (last visited May 25, 2012).

324 Conclusory, Your DictionARY, http://www.yourdictionary.com/conclusory (last visited May 25, 2012).

325 Conclusory, THE FREE DiCTIONARY, http://www.thefreedictionary.com/conclusory (last visited May 25, 2012) (emphasis omitted).

326 Conclusory, DictionARy.COM, http://dictionary.reference.com/browse/conclusory (last visited May 25, 2012).

327 Conclusory, FINDLAw, http://public.findlaw.com/LCsearch.html?entry=conclusory (last visited May 25, 2012).

${ }^{328}$ Legal Dictionary, LAw.COM, http://dictionary.law.com/Default.aspx?typed=conclusory\&type=1 (last visited May 25, 2012).

${ }^{329}$ LAW DiCTIONARY, http://www.law-dictionary.org/ld.asp?q=conclusory (last visited May 25, 2012).
} 
Black's and Ballentine's do not have official public websites, undoubtedly due to exclusive contracts with Westlaw and LEXIS and the need to protect their own subscriber services.

Wiktionary.org defines "conclusory" as "1. Of or pertaining to a conclusion; conclusive. 2. Law: Offering a conclusion without supporting factual evidence; question-begging;" it provides the usage example of "[t]hese claims are conclusory and universally unsupported by any specific allegations. ${ }^{\text {"31 }}$ Wikipedia.org does not find an article for "conclusory." "332

The dictionary at Google.com has an interesting entry for "conclusory" with usage and definition listings. It borrows the Wiktionary.org definition but adds three usage examples, two of which relate to legal allegations, but also a third, broader, usage regarding generally unsupported assertions in newspaper articles. ${ }^{333}$

${ }^{330}$ Nolo's Plain-English Law Dictionary, NoLO, http://www.nolo.com/dictionary/ (last visited May 25, 2012).

${ }^{331}$ Conclusory, WIKTIONARY, http://en.wiktionary.org/wiki/conclusory (last modified Mar. 27, 2012).

332 WIKIPEDIA, http://en.wikipedia.org/wiki/Special:Search?search=conclusory\&go=Go (last visited May 25, 2012). Seeing as Wikipedia is built on user-generated content, one could, I presume, add a definition. In case any entrepreneurial reader is further curious, a search in the reader-populated "alternative" website Urban Dictionary similarly explains that "conclusory hasn't been defined yet," although I am not sure if "conclusory" is hip enough to meet editorial standards there. URBAN DICTIONARY, http://www.urbandictionary.com/define.php?term=conclusory (last visited May 25, 2012).

333 Google Dictionary, http://www.google.com/dictionary?langpair=en\%7Cen\&q=conclusory\&hl= en\&aq $=\mathrm{f}$ (last visited Feb. 6, 2011). Google provides the following three usage examples:

- Asked if he accepted Gonzales' assertions, Specter, a Pennsylvania Republican, told ABC's "This Week," "I do not. Those statements are very conclusory. When he has a full column of The Washington Post, I think he would have been better advised if he would have dealt with some facts." See Kyle Sampson, Specter: Gonzales to Face "Serious Questions" on Firings, CNN, Apr. 15, 2007, http://articles.cnn.com/2007-04-15/politics/gonzales_ 1_improper-reason-kyle-sampson-attorney-general-alberto-gonzales?_s=PM: POLITICS.

- "No court has ever certified a case like this," said Chief Justice Alex Kozinski, who wrote for the minority, and said the case opens the door for further lawsuits "based on nothing more than general and conclusory allegations, a handful of anecdotes, and statistical disparities." See Willie Larger, Ninth Circuit Court Rules Against Wal-Mart, POLitiCALlyIllustrateD.COM (Apr. 26, 2010), http://politicallyillustrated .com/index.php/news_page/law/1065/.

- "Stripped of his conclusory adjectives and adverbs, his allegations say that he has been searched or detained at airports," Sentelle wrote. "It is unlikely that anyone who flies with any frequency has not." See Mike Scarcella, Fanciful or Not, Court Gives Spying Suit Second Chance, BLOG OF LEGAL 
U N I V E R S I T Y O F P I T T S B U R G H L A W R E V I E W

PAGE

Macmillan Dictionary online has no entry for "conclusory." 334 And searches in Oxford Dictionaries Online ${ }^{335}$ and Cambridge Dictionaries Online, ${ }^{336}$ each of which claims to have all of its imprint's dictionaries in its database, find no occurrences of the word "conclusory."

A few things are clear. Dictionaries are coming around and increasingly realizing that "conclusory" is a word worthy of recognition and inclusion. The definitions vary in sometimes significant ways. And many dictionaries are still in need of a lesson from the course of usage documented in Part I to catch up with the reality of use of the term "conclusory."

\section{E. The Limitations of Dictionaries}

Perhaps it does not matter that dictionaries tell us little about the meaning of "conclusory" or that they have been late and unreliable in supplying a definition. Perhaps dictionaries should not matter, or at least not matter so much. Dictionaries, while useful in many respects, have limitations. ${ }^{337}$ These inherent, general limitations justify, at best, cautious and limited reliance on dictionaries to determine meaning in the context of judicial standards based on words like "conclusory." Only by understanding the limitations of dictionaries and by recognizing their limitations can one likewise gauge the appropriate reliance on them in the law ${ }^{338}$ - an exercise of maturity and wisdom, says Learned Hand, who

TiMES (Feb. 20, 2009, 4:41 PM), http://legaltimes.typepad.com/blt/2009/02/

fanciful-or-not-court-gives-spying-suit-second-chance.html.

Google Dictionary was apparently discontinued in August 2011, and its webpage is no longer active. A copy of the reported page above is on file with the author.

334 MACMILLAN DICTIONARY, http://www.macmillandictionary.com/spellcheck/british/?q=conclusory (last visited May 28, 2012).

${ }^{335}$ OXFORD DiCTIONARIES, http://oxforddictionaries.com/ (last visited May 28, 2012).

336 CAMBRIDGE DiCTIONARIES ONLINE, http://dictionary.cambridge.org/spellcheck british/?q= conclusory (last visited May 28, 2012).

${ }^{337}$ See generally D.S. Bland, Some Notes on the Evolution of the Legal Dictionary, 1 J. LEGAL HIST. 75 (1980); Gary L. McDowell, The Politics of Meaning: Law Dictionaries and the Liberal Tradition of Interpretation, 44 AM. J. LEGAL HIST. 257 (2000) (discussing the history of dictionaries and the importance of words and understanding their meaning); Aaron J. Rynd, Dictionaries and the Interpretation of Words: A Summary of Difficulties, 29 ALTA. L. REV. 712 (1991).

${ }^{338}$ See Rubin, supra note 196, at 178 ("[T] understanding of the creation of dictionaries and of lexicography - the science of determining the meaning of words."). 
exhorted that "it is one of the surest indexes of a mature and developed jurisprudence not to make a fortress out of the dictionary.",339

The history of dictionaries, including law dictionaries, and the lexicographical approach, has been complex and evolving over time. ${ }^{340}$ From that history, a few insights on some specific limitations of dictionaries as trustworthy legal authority become evident.

Dictionaries are products demanded by consumers seeking linguistic guidance. ${ }^{341}$ But these consumers must be wary of over-reliance. "There have always been nagging doubts about the legitimacy of resorting to dictionaries to find legal meaning ...." 342 Sidney Landau has cautioned that a "[d]efinition never determines correctness. ${ }^{343}$ Instead, a dictionary's "basic purpose [is] giving the reader enough immediate information [about a word] to enable him to surmise, at least approximately, its meaning in context. ${ }^{\text {344 }}$

Dictionaries are simply not all-encompassing, monolithic, universal, or perfectly neutral authority. ${ }^{345}$ Dictionaries differ in approach between the prescriptive and the descriptive, a fact that engenders debate and also means that one's choice of dictionary may make a difference in the definition found. ${ }^{346}$

${ }^{339}$ Cabell v. Markham, 148 F.2d 737, 739 (2d Cir. 1945).

${ }^{340}$ See Thumma \& Kirchmeier, supra note 197 (providing extensive history of the dictionary and the law dictionary with appendices organized by term, justices, and dictionary). Appendices published as: Dictionaries Relied Upon by the United States Supreme Court to Define Terms Through the 1997-1998 Term, 47 Buff. L. Rev. 471 (1999); United States Supreme Court Justices Citing Dictionaries Through the 1997-1998 Term, 47 Buff. L. REV. 397 (1999); Terms Defined By the United States Supreme Court Through the 1997-1998 Term, 47 BufF. L. REv. 303 (1999). See generally Rubin, supra note 196 (surveying the methods of creation for dictionaries from a historical and lexicographical perspective).

${ }^{341}$ Bryan A. Garner, Making Peace in the Language Wars, 7 GREEN BAG 2D 227, 234 (2004) (“[L]iterate people continue to yearn for guidance on linguistic questions.").

${ }^{342}$ McDowell, supra note 337, at 258.

${ }^{343}$ SidNEY I. LANDAU, DictionARIES: THE ART AND CRAFT OF LEXICOGRAPHY 148 (1984).

${ }^{344}$ Id. at 131. See also S.I. Hayakawa, How Dictionaries Are Made, in THE SEAGUll READER: EsSAYS 69, 71 (Joseph Kelly ed., 2002) (emphasis omitted) ("The writing of a dictionary, therefore, is not a task of setting up authoritative statements about the 'true meanings' of words, but a task of recording, to the best of one's ability, what various words have meant to authors in the distant or immediate past.").

${ }^{345}$ Rubin, supra note 196, at 177 ("[E]ven the notion of 'the dictionary' as one monolithic concept is troublesome: there are many dictionaries with different purposes, focuses, budgets, constraints, and methodologies.").

${ }^{346}$ Thumma \& Kirchmeier, supra note 197, at 242 (describing the prescriptive/descriptive dictionary differences and debates); Rubin, supra note 196, at 184 (describing the differences between prescriptive and descriptive dictionaries). 
Nonetheless, dictionaries run the risk of being captive to a lexicographer's predisposition, including the temptation to leave out words. ${ }^{347}$ The battle between specificity or precision in definition versus breadth of application, the reality of space constraints, dealing with the necessity for abstraction, and the demand for brevity all mean that dictionaries are not intended to be definitive or authoritative texts on a particular word's meaning, especially in isolation. ${ }^{348}$

As a consequence of all of these things, dictionaries must leave out certain words $^{349}$ - as the history of "conclusory" demonstrates. The Google Labs team certainly "found more words than appear in any dictionary" in their project, for example. ${ }^{350}$

In deciding which words to include and then in crafting the definitions for those words, lexicographers aim to make definitions fit usages, ${ }^{351}$ but it is impossible to fully capture many words' full meaning as actually used. ${ }^{352}$ Because of the importance of words in context, some have argued that, in law, particularly, usage dictionaries are far more valuable than the traditional definition-based dictionary. ${ }^{353}$ The best dictionaries focus on usage, ${ }^{354}$ but even then can only give

\footnotetext{
${ }^{347}$ Tiersma, supra note 207, at 286 ("Lexicographers of the past sometimes let their own predispositions influence how they defined a word. They might leave out a word entirely, or ignore a common meaning of a word, because they deemed it unacceptable.").

${ }^{348}$ Aprill, supra note 248, at 293-97.

${ }^{349} I d$. at 296. Thumma \& Kirchmeier, supra note 197, at 243-44 (“[I]n light of space, cost and other limitations, most dictionaries are not comprehensive and do not purport to include all possible definitions.").

${ }^{350}$ The Google Labs researchers, for example, stated that "[n]otably we found more words than appear in any dictionary .... This gap between dictionaries and the lexicon results from a balance that every dictionary must strike: it must be comprehensive enough to be a useful reference, but concise enough to be printed, shipped, and used." Michel et al., supra note 15.

${ }^{351}$ Rubin, supra note 196, at 178 ("[C]reation of a dictionary has always involved amassing examples of usage, which requires a tremendous amount of historical research.").

${ }^{352}$ See infra Parts IV-V.

${ }^{353}$ Mellinkoff, supra note 197, at 423 (advocating for a move to usage dictionaries and detailing the evolution and history of legal dictionaries). But see, e.g., Roy M. Mersky \& Jeanne Price, The Dictionary and the Man: The Eighth Edition of Black's Law Dictionary, Edited by Bryan Garner, 63 WASH. \& LEE L. REV. 719, 724 (2006) ("Unlike books written on style and usage (legal or otherwise) ... dictionaries are used frequently, in a variety of situations, and by very different individuals.").

${ }^{354}$ Aprill, supra note 248, at 284 ("[M] odern lexicographers try to describe how words are being used in context by considering a wide variety of sources ....").
} 
the reader a snapshot from high above for only part of the lexicon, ${ }^{355}$ and even then, do not provide the pinpoint focus that must be taken into account with each individual use of a word. For a variety of reasons, some usages will be missed while others will be disregarded. ${ }^{356}$

Dictionaries are reference books and starting points for research; they are not treatises and they do not replicate a text of scientific definitiveness and proof. Lexicographers themselves recognize these limitations. ${ }^{357}$ Lexicographers have great skill and expertise and are to be applauded for their research and craft. But lexicographers are language assistants, not definition authoritarians. As such, their product can be helpful, but should not be deemed determinative. ${ }^{358}$ Moreover, as also seen by the example of "conclusory," the omission of legal terms from general dictionaries is not rare-for one thing, the "citation lists" used by general dictionary lexicographers do not include legal sources of usage, because they are not generally searched. ${ }^{359}$

Thus, the general dictionary lexicographer would not have compiled much of the information provided in Part I of this article. One purpose of legal dictionaries is to fill in these gaps, ${ }^{360}$ although as we have seen, they have been slow in relation to the term "conclusory." Moreover, even for legal dictionaries, lexicographers search and compile citation lists as guides to deciding which words to include that are not comprehensive of usages within the profession, as these references

\footnotetext{
${ }^{355}$ Rubin, supra note 196, at 184-85 ("Dictionaries come in many different sizes, designed for many different uses. The entire English lexicon is estimated to be about four million words, yet even an unabridged dictionary might contain only 450,000 of them .... So-called college dictionaries, by far the most popular general-use dictionaries in the United States, are smaller, typically containing only 160,000 to 180,000 entries.").

${ }^{356}$ Aprill, supra note 248, at 289 ("Quite apart from constant change, citation files, although crucial, are flawed. Of course, 'no one's file is perfectly comprehensive; many usages will be missed."').

${ }^{357}$ Note, Looking It Up: Dictionaries and Statutory Interpretation, 107 HARV. L. REV. 1437, 1452 (1994) [hereinafter Looking It Up] ("Lexicographers recognize that the definitions and categories provided in dictionaries can never be perfect, but they seek to achieve the best possible fit in order to assist the reader."). Aprill, supra note 248, at 309 ("The [Sixth] edition of Black's Law Dictionary tries valiantly not to perpetuate the myth of authority and precision.").

${ }^{358}$ Solan, supra note 216 , at 53 ("The business of the lexicographer is to try . . to describe the necessary and sufficient conditions for membership in a conceptual category based on examples of the word's usage in the past .... Inevitably, the lexicographer's success will only be partial, even in the best dictionaries.").

${ }^{359}$ Aprill, supra note 248, at 291 (“'[G]eneral dictionaries exclude legal sources and thus will exclude any special legal meanings of common words.”).

${ }^{360}$ Id. at 303.
} 
primarily focus on case law. ${ }^{361}$ And law dictionaries, too, face the same constraints and battles between breadth and precision. ${ }^{362}$ There is also a recognized time lag between the research on usage and the publication of a dictionary, meaning dictionaries may be compiled before a word has reached a level worthy of inclusion, but published with a date after the point at which the word would justifiably be included. ${ }^{363}$

Although many courts have themselves turned to dictionaries to assist in their decisions, particularly in statutory interpretation, the ways in which they have been used and the level of deference that has been given to them has varied, and there is some debate as to whether resort to dictionaries is appropriate even in those circumstances. ${ }^{364}$ When multiple definitions exist for the same word, relying only

${ }^{361}$ Id. at 308 ("Other legal sources, such as other publishers, law school publications, hornbooks, professional publications, and, of particular importance for the subject of this piece, legislation and legislative history, however, are not systematically searched.").

${ }^{362} I$ d.

${ }^{363}$ Aprill provides some interesting background:

\begin{abstract}
As a result of constant change and growth in language, dictionaries are out of date by the time they are published. College dictionaries are thoroughly revised only every ten years or so, although they are generally updated every year in order to ensure an "up-to-date copyright date." Almost thirty years passed between the second and third editions of Webster's Third, with the second edition published in 1934, and the third in 1961. There is not yet a fourth edition. Reprints of the third edition now include an addendum of some fifty-five pages of new words and new meanings. The gap between the first and second editions of the OED is even longer. The first edition of the OED was published as a series of volumes between 1882 and 1928, and then published as a twelve-volume set in 1933. The second edition was published in 1989.
\end{abstract}

Aprill, supra note 248, at 287 ("Because of the inevitable time delay between collection of citations and publication of a dictionary, dictionaries must lag behind current use of the language."); Thumma \& Kirchmeier, supra note 197, at 294 ("[D] escriptive dictionaries inherently suffer from issues of time lag and cannot immediately include new usage or slang .... [W] hether prescriptive or descriptive, the general usage dictionary cannot provide the end point of the Court's analysis in defining terms.").

${ }^{364}$ Thummer and Kirchner explained in an excellent history of the use of dictionaries by courts:

The Court has relied on dictionaries to define words and phrases for nearly 170 years, and yet there are few real guidelines for when such use is proper or how the dictionary should be used generally. Rather, the Court's approach in using dictionaries has varied and is inconsistent on many levels. Opinions relying upon a dictionary have differed in several major respects in determining the appropriate definition, in selecting the proper dictionary, in selecting the proper edition and even in agreeing on the proper word to be defined. 
on a dictionary can become a subjective decision. ${ }^{365}$

Courts should be cautious in trusting dictionary definitions because of all of these limitations. Moreover, courts should realize that the choice of what dictionary to cite may, in fact, represent a certain preference for a particular definition rather than provide some objective or neutral means for decision. ${ }^{366}$ As Part IV.C above and the next subsection show, dictionaries have a variety of definitions for "conclusory," which could potentially produce divergent outcomes when applied in particular cases.

Professor Aprill counsels well: "In sum, no dictionary has a monopoly on the truth .... Dictionary definitions are only generalizations, summaries, and approximations. Their definitions are not right or wrong in any absolute, objective sense. ${ }^{\$ 67}$ If we were to rely on dictionaries to determine the full extent of the legitimate vocabulary or usage, our language would be static and impervious to linguistic innovation. ${ }^{368}$ Words like "conclusory," even when unrecognized, are testaments to the elasticity of language. If we rely too heavily on dictionary definitions of isolated words to determine complex applications of words in law, we equally risk rigidity and error.

As long as our expectations are controlled, dictionaries are a valuable reference. ${ }^{369}$ Providing a general sense of a word is a perfectly legitimate function

Thumma \& Kirchmeier, supra note 197, at 290. See also Looking It Up, supra note 357, at 1437, 1447 (discussing the increasing use of interpretive tools by courts, lamenting that "the use of dictionaries as interpretive tools has received little scrutiny" and arguing that "[t]he Supreme Court has failed to use dictionaries in such a principled manner"); Solan, supra note 216, at 56 ("Turning to dictionaries may help courts establish a seemingly principled basis for their decisions. However, inappropriate resort to the dictionary does nothing to advance judicial argumentation ....").

${ }^{365}$ See Looking It Up, supra note 357, at 1445-46 (“A greater problem with dictionary meanings is their fundamental indeterminacy ... The same arguments about manipulability and arbitrariness that textualists use to attack the examination of legislative history can therefore be applied to dictionaries.").

366 Thumma \& Kirchmeier, supra note 197, at 290. See also Looking It Up, supra note 357, at 1437, 1447; Solan, supra note 216, at 56.

${ }^{367}$ Aprill, supra note 248, at 297.

368 Ambrose Bierce, The Devil's Dictionary 71 (Forum Books 1948) (1911) (“Dictionary, n. A malevolent literary device for cramping the growth of a language and making it hard and inelastic.").

${ }^{369}$ See Solan, supra note 216, at 54 ("Throughout most of our daily endeavors ... [w] are satisfied when a dictionary gives us a good two-line approximation of a word's meaning, and we have no reason to expect any more."). 
for the dictionary, ${ }^{370}$ and that is true, too, for our first step in understanding the meaning of "conclusory" in Iqbal. Samuel Johnson put it this way: "Dictionaries are like watches, the worst is better than none, and the best cannot be expected to go quite true. ${ }^{, 371}$ When accepted for what they are, dictionaries are good starting points for understanding words, but they are no substitute for context. ${ }^{372}$

\section{F. Garner's Definitions: A Closer Look and Case Study in Dictionaries' Limitations}

Despite the inherent limitations of dictionaries, lexicographers have nonetheless historically helped shape the legal lexicon. ${ }^{373}$ At least regarding the word "conclusory," that can certainly be said of Bryan Garner. As I am not a lexicographer, and nothing in this Part is intended to criticize Garner for his lexicographical skill or choices. ${ }^{374}$ The comments here do not apply the metrics of lexicographical quality, whatever those may be. Instead, it simply questions whether courts and litigators can rely on existing dictionary definitions to define the legal standard pronounced in Iqbal. ${ }^{375}$ It should be noted that Garner himself

${ }^{370} I d$. at 55 ("[In some] cases, the dictionary is used to give the reader a general sense of the word (....").

371 James Boswell, The Life of SAmuel JohnSON, LL.D 438 (Thomas Davison, Whitefriars 1831) (1791).

${ }^{372}$ Looking It Up, supra note 357, at 1452 ("Difficulties arise from assuming that dictionaries provide perfect category boundaries and then applying those boundaries to contexts never considered by the authors of the dictionaries.").

${ }^{373}$ Professor Mersky writes:

Lexicographers have had a profound impact on the development of legal systems in the English-speaking world. Since the time of John Rastell, legal dictionaries have not only defined key terms and concepts, but in many cases have also determined the very topics and issues that have come to dominate contemporary legal thinking. The rich history of legal dictionaries offers fascinating insights into the evolution of legal thinking and also provides a better understanding of influences on the dynamic relationship between words and deeds.

Mersky, supra note 6, at 32 .

${ }^{374}$ Samuel Johnson, Preface to a Dictionary of the English Language 2 (Kessinger Publishing 2004) (1755) ("Every other author may aspire to praise; the lexicographer can only hope to escape reproach.").

${ }^{375}$ Solan has stated that "[ $[$ t]he business of the lexicographer is . . . to do what . . cannot be done ...." Solan, supra note 216, at 53. Garner has done as much as can be done for the word "conclusory," as far as dictionaries go, but transforming them into authoritative sources for ascertaining a judicial standard like in Iqbal is not something that can be done. 
has stated lawyers should not cite dictionaries as authority. ${ }^{376}$ This section provides some examples supporting that conclusion as it relates to the word "conclusory."

The addition of "conclusory" to the seventh edition of Black's in 1999 is attributable to that famed dictionary's new editor-in-chief, Bryan Garner. ${ }^{377}$ Garner is the one who first reported the absence or omission of "conclusory" from dictionaries in his well-received 1987 reference book, Modern Legal Usage. ${ }^{378}$ Prior to the seventh edition, Black's had been criticized for its lack of a professional staff, the absence of editorial leadership, and a failure to maintain a reference current to modern usage. ${ }^{379}$ The advent of Garner's leadership has primarily been heralded as a dramatic improvement in the coverage, quality, and utility of Black's as a legal reference guide. ${ }^{380}$ Among the compliments, his work has been described as "a judgmental hand applied to exhaustive research and thorough analysis." ${ }^{381}$ And Black's seems to have solidified its standing as the most authoritative legal dictionary currently in publication. ${ }^{382}$

${ }^{376}$ A commenter once stated in a review of the Oxford Law Dictionary that "Garner adds, 'if you're a self-respecting lawyer, you don't cite law dictionaries." Chineson, supra note 250, at 30.

${ }^{377}$ Tiersma, supra note 207, at 286 (calling the 7th and 8th editions "Garner's reworking of Black's").

${ }^{378}$ GARnER, MOdern Legal Usage, supra note 13.

379 Compare Aprill, supra note 248, at 307 ("Unlike modern general dictionaries, Black's Law Dictionary has no internal professional staff engaged in a regular and ongoing reading program of representative legal texts for purposes of the dictionary."), with Mersky \& Price, supra note 353, at 727 ("In style, the seventh and eighth editions are concise and reflective of modern usage.").

${ }^{380}$ See, e.g., Mersky \& Price, supra note 353, at 719. According to Mersky and Price:

Bryan Garner is a man with a mission: a dictionarian, if not a dictioneer. Garner, in again updating and revising the "standard U.S. law dictionary," seeks not only to accurately define a comprehensive list of legal terms, but more fundamentally, to elevate legal scholarship. It is an ambitious undertaking (and one whose premise might be questioned by many scholars). But if there is anyone suited for such pursuits, in both intellect and temperament, it is Bryan Garner.

Id.; Tiersma, supra note 207, at 285 (calling the 7th and 8th edition revisions to Black's Law Dictionary "a remarkable revitalization of an old workhorse").

${ }^{381}$ Mersky \& Price, supra note 353, at 732.

${ }^{382}$ Mersky and Price summarize Black's predominance as follows:

The eighth edition of Black's, continuing the mission begun in the seventh, seeks to educate, inform, analyze, and describe from a higher perspective. Garner's definitions are current and succinct, yet are placed in a historical perspective and in a context of usage that is sensible and, in many cases, 
U N I V E R S I T Y O F P I T T S B U R G H L A W R E V I E W

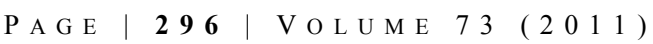

Garner defines himself as a "descriptive prescriber." 383 Peter Tiersma has described his approach and contribution to Black's Law Dictionary as follows:

Black's has improved because Garner has instituted sound lexicographic principles. Most importantly, his definitions are based upon actual usage by the profession. He and his staff have combed through a vast assortment of legal texts, including not just the predictable statutes and judicial opinions, but also legal encyclopedias, restatements, law reviews, treatises, and even the Nutshell series. Garner also had three distinguished scholars vet the entire manuscript of the seventh edition, and asked an additional 30 lawyers, judges, and academics to read parts of it. ${ }^{384}$

As far as dictionaries go, Black's has gone farther than many by at least providing us with a definition and by recognizing the importance of inclusion for the term "conclusory."

Black's holds a preeminent place in legal definition and is turned to often by the courts when they choose to reference a dictionary. ${ }^{385}$ Lawyers and judges will undoubtedly migrate toward Black's to search for a meaning of "conclusory," whether it be to interpret Iqbal or for other reasons. Thus, this section seeks to explore the limitations of Black's in understanding a judicially recognizable conclusory standard post-Iqbal, and it also seeks to help us question Black's definition in light of slightly different definitions provided in other publications also written by Garner.

Table 5 sets forth all of the available published definitions across Garner's portfolio of work for the word "conclusory." Upon close examination, there are slight differences between the definitions although the same general, broad

enlightening .... Black's is the last standing comprehensive American legal dictionary intended for a wide audience.

Id. at 720 .

${ }^{383}$ Garner, supra note 341, at 230 (calling himself "a kind of descriptive prescriber"); Thumma \& Kirchmeier, supra note 197, at 292-93 ("[A]11 dictionaries[] fall somewhere in the prescriptive/descriptive continuum.").

${ }^{384}$ Tiersma, supra note 207, at 285.

${ }^{385}$ Mersky \& Price, supra note 353, at 730 ("But the relevance of dictionaries in general, and of Black's in particular, to modern jurisprudence is best illustrated by the attention given to those works by American courts, most notably the United States Supreme Court."); Thumma \& Kirchmeier, supra note 197, at app. A. 
While EFfuSiVE, “CONCLUSORY” IS STIL L E L U IVE

\begin{tabular}{l|r}
$P$ A G E & 297
\end{tabular}

concepts are captured in each. These slight differences - if focused on by a court of law - could lead to potentially different degrees of scrutiny for courts attempting to apply the first prong of Iqbal and to determine which allegations are to be disregarded and deemed insufficient to withstand a motion to dismiss.

\section{Table 5}

\section{Bryan A. Garner's Definitions of Conclusory}

BRYAN A. GARNER, A DiCTIONARY OF MODERn LEGAL USAGE 135 (1st ed. 1987)

"Expressing a mere conclusion of fact without stating the specific facts upon which the conclusion is based."

Bryan A. Garner, Novelties in Lawyer Talk, APPELLATE AdVocATE, Summer 1989

"expressing a mere conclusion of fact without stating the specific facts upon which the conclusion is based."

Bryan A. Garner, The Missing Common-Law Words, in THE STATE OF THE LANGUAGE 235, 239-49 (Christopher Ricks \& Leonard Michaels eds., 1990)

"Expressing a mere conclusion of fact or a factual inference without stating the underlying facts on which the conclusion or inference is based."

BRYAN A. GARNER, THE ELEMENTS OF LEGAL STYLE 107 (1991)

"expressing a factual inference without expressing the facts on which the inference is based."

Bryan A. GARner, A DiCtiONARY OF MODERn LEGAL USAGE 191 (2d ed. 1995), 192 (3d ed. 2011)

"expressing a factual inference without expressing the fundamental facts upon which the inference is based," adding, "The word often describes evidence that is not specific enough to be competent to prove what it addresses."

BRYAN A. GARNER, GARNER's MODERN AMERICAN USAGE 146 (1st ed. 1998) "expressing a factual inference without stating the fundamental facts on which the inference is based <conclusory allegations $>$."

BLACK'S LAW DICTIONARY 284 (7th ed. 1999), 308 (8th ed. 2004) 329 (9th ed. 2009)

"[e]xpressing a factual inference without stating the underlying facts on which the inference is based. <because the plaintiff's allegations lacked any specific evidence they were merely conclusory $>$ "

Bryan A. GARner, THE REDBOOK: A MANUAL ON LEGAL STYle 195 (2002) \& $226(2$ d ed. 2006)

"a statement that puts forth a conclusion but not the reasoning behind it."

BRYAN A. GARNER, GARNER's MODERN AMERICAN USAGE 174 (2d ed. 2003) \& 178 (3d ed. 2009)

"expressing a factual inference without stating the facts or reasoning on which the inference is based < conclusory allegations $>$." 
Comparing the definitions in Table 5, one is forced to ask a number of questions. Most of these cannot be resolved with certainty—or at least a litigant cannot know how any particular judge might resolve them.

Is there a difference between "expressing a mere conclusion" and "expressing a factual inference?" Courts could easily latch onto words like "mere" as having profound significance, for example, illustrating that the definition the court uses could affect the outcome, and the existence of multiple definitions could indeed allow a judge to pick the one that seems more or less restrictive.

Is there a difference between "without stating the specific facts" and "without stating the fundamental facts" and "without stating the underlying facts" and "without stating the facts or reasoning?" The choice of definition-meaning a choice of modifier - could alter the substance of the evaluation.

Is there a difference between upon "which the conclusion is based" and "which the inference is based" and "which the conclusion or inference is based" and "which the reasoning is based?"

All of these permutations look significant, even if they were not intended to be. The negative risk of construing the words in each as informative is especially high, if one mistakenly considers a dictionary authoritative in some manner. These differences illustrate the cautionary tale that dictionaries are guidance documents and not authoritative ones.

All of Garner's definitions are similar, but subtle differences exist between them. It is not clear what accounts for these differences - perhaps the passage of time led to greater attempts at precision or generality. The struggle between specificity and generality is well known in lexicography. Some of the differences in Garner's definitions must, of course, be considered in relation to the differences in the target audience for each publication and the intended lessons to be conveyed by the definitions. ${ }^{386}$ The venue and the intended audience where the definition appears might account for some of the differences, but that explanation is less convincing when the definition changed between different editions of the same publication.

And then we are also left with the question of whether or not any of the other Garner definitions should inform our interpretation of the Black's definition. For example, is the fact that "fundamental" is not used in Black's significant? Was it an

\footnotetext{
${ }^{386}$ See Rubin, supra note 196, at 178 ("Dictionaries can focus on different kinds of readers as well . . . These differences require decisions ... that affect the sources chosen for the dictionary, the methodology used in constructing definitions, and the words and definitions included.").
} 
intentional omission, an oversight, or an indication that the word is implied? Of course, there may be answers, and Garner or others may have them. But that is irrelevant, for those flipping to the page in the dictionary will not find those answers.

When one compounds the difficulties in choosing any one of Garner's definitions over another with the variety of other dictionary definitions of slightly or substantially different phrasing, some of the limitations of reliance on a dictionary for authority in construing a court-announced standard announced are revealed. Dictionaries are not well suited to mechanical application for understanding real-world situations of use. ${ }^{387}$

This section and Part IV have taught much history and some lessons about dictionaries generally and the term "conclusory" within them, specifically. Relying on the dictionaries to understand the first prong of Iqbal has three general problems: (1) the dictionary definitions do not tell us much, indeed sometimes do not even exist; (2) dictionary definitions cannot be authoritative of the meaning of a term and cannot capture a word's contextual character; and (3) Garner's definitions all risk asking more from pleadings to the extent they hint at a need for evidentiary support at the pleadings stage. ${ }^{388}$

Words in law gain their legitimacy almost exclusively from how they are used ${ }^{389}$ and dictionaries can only go so far in capturing usage. We are asking more of a lexicographer than his occupational charge if we demand that his definitions provide answers to understand the placement of such words in a chosen phrase of a judge. " $[\mathrm{M}]$ odern legal dictionaries, like modern general dictionaries, do not—and were not intended to-dictate meaning.",390

\footnotetext{
${ }^{387}$ Smith, supra note 5, at 126 (“"A] good dictionary should rebuff any suggestion that words and phrases can be looked up with the expectation of mechanical exactness. Cardozo summed up the modern approach: 'Law never is but is always about to be. It is realized only when embodied in a judgment, and in being realized, expires." (citing BenJAmin N. CARdozo, THE NATURE OF THE JUdicial Process 26 (1921))).

${ }^{388}$ Steinman, supra note 63, at 1329.

${ }^{389}$ Mersky and Price explained that "[l]aw, and more specifically, the rituals and mechanisms through which it is pronounced, invests words (and their senses) with legitimacy and authority; it is the obligation of the law dictionary to reflect those meanings and evidence the authority supporting them." Mersky \& Price, supra note 353, at 722.

${ }^{390}$ Aprill, supra note 248 , at 309.
} 
U N I V E R S I T Y O F P I T T S B U R G H L A W R E V I E W

PAGE

\section{After IQbal: Argument by Analogy May Be the LAST, BEST HOPE TO UNDERSTAND WHAT “Conclusory" Means for Purposes of Pleading}

Judicial opinions are rich and dense, and the use of a word in an opinion, let alone in a standard, cannot be understood or interpreted simply by attaching a dictionary definition. "There is not a single ordinary meaning of a word; meaning varies depending on how and where it is used. ${ }^{391}$ In a judicial standard like we see in the first prong of Iqbal, the usage is too complex to "superimpose" the definition into the middle of the string within which the word is used. ${ }^{392}$ Others have reached a similar conclusion in the use of dictionary definitions to understand complicated statutory language. ${ }^{393}$ Thumma and Kirchmeier's conclusions on the use of dictionaries to interpret statutory terms are equally applicable to the use of dictionary definitions to interpret the judicial analog to a statute- a standard pronounced in a judge's opinion:

Definitive reliance on law dictionaries to define terms suffers from defects similar to such reliance on general usage dictionaries. In addition, many terms in a law dictionary are legal terms and, frequently, terms of art. Thus, the definitions provided in a law dictionary are either: (1) based on case law or usage (such as statutory terms) or (2) created anew by the dictionary's editorial board. If based on case law or usage, the best source for a definition is the decision or usage in context. Prior decisions and usage, defining the term in context, should be far more instructive than the definitions in a law dictionary, which are general paraphrases that lack any context. And if, rather than being based on case law or usage, the law dictionary definition was created anew, one might ask whether that definition should be afforded any weight at all. ${ }^{394}$

${ }^{391}$ Id. at 303. See also Rickie Sonpal, Note, Old Dictionaries and New Textualists, 71 FORDHAM L. REV. 2177, 2206 (2003) ("Dictionaries, by their very nature, do not provide the precise meaning of a word as it is used in a particular context.").

392 S.I. HAyAKAWA, LANGUAGE IN THOUght AND ACTION 57-58 (4th ed. 1978) (discussing utility of using dictionaries for determining "areas of meaning" surrounding a word).

${ }^{393}$ Aprill, supra note 248, at 335 ("[Dictionary] definitions are quick pencil sketches of our colorful, growing, and ever-changing English language. These sketches should not be superimposed onto the dense texture of statutory language.").

${ }^{394}$ Thumma \& Kirchmeier, supra note 197, at 294-95. Rubin gives similar advice:

Professor Craig Hoffman notes that "[1]inguists hypothesize that humans are born with a certain 'genetic endowment' that predisposes us to use language," and that this skill facilitates the internalization of certain 
The dictionary definitions of "conclusory" should be the beginning, but not the end, of the inquiry to determine the meaning of the first prong in Iqbal. ${ }^{395}$ The Supreme Court has cautioned that "one definition of a word does not express its whole meaning or necessarily determine the intention of its use." "396 That warning is equally applicable when it comes to understanding the meaning of "conclusory" in the first prong of Iqbal.

At the very least, this article seeks to disabuse litigants seeking to understand Iqbal of the "myth of precision" behind any dictionary definition of "conclusory." 397 The words and circumstances surrounding the use of one word are

\begin{abstract}
unspoken rules about structure and meaning, which allow readers to understand sentences when words or phrases are unclear. This, in turn, makes consideration of the surrounding context essential to actually understanding what a sentence means. Using a lexicographic analysis is simply taking a word out of a sentence and defining it. The better method is to view words within their context- to "parse the statutory sentence and to explore the syntactic relationships among its constituents." Dictionaries, therefore, "are less helpful when the inquiry properly extends beyond the word level," as statutory interpretation always does.
\end{abstract}

Rubin, supra note 196, at 188-89 (quoting Craig Hoffman, Parse the Sentence First: Curbing the Urge to Resort to the Dictionary When Interpreting Legal Texts, 6 N.Y.U. J. LEGIS. \& PUB. POL'Y 401, 402, 406, 408 (2003)).

${ }^{395}$ Thumma \& Kirchmeier, supra note 197, at 296 (“Although dictionaries cannot provide the end point in defining terms, dictionaries are a proper and useful source in determining what a word may mean."); $i d$. at 300 ("Dictionaries can be valuable resources in determining the history, origin and potential meaning of a term .... Using dictionaries at the beginning of the definitional process, rather than at the end, properly exploits dictionaries as a source of potential meaning while, at the same time, reflects the inherent limits of dictionaries.").

${ }^{396}$ Osborne v. San Diego Land \& Town Co. of Me., 178 U.S. 22, 38 (1900).

${ }^{397}$ Mellinkoff, supra note 197, at 426 ("I suggest that the law dictionary is indeed a symbol, not of precision, but of the myth of precision, and that something can be done about it, the myth and its symbol."). Randolph explained a need to overcome an "optical illusion" indulged by over-reliance of dictionary definitions:

Yet citing to dictionaries creates a sort of optical illusion, conveying the existence of certainty — or "plainness"-when appearance may be all there is. Lexicographers define words with words. Words in the definition are defined by more words, as are those words. The trail may be endless; sometimes, it is circular. Using a dictionary definition simply pushes the problem back.

A. Raymond Randolph, Dictionaries, Plain Meaning, and Context in Statutory Interpretation, 17 HARV. J.L. \& PUB. POL'Y 71, 72 (1994). 
U N I V E R S I T Y O F P I T T S B U R G H L A W R E V I E W

PAGE

a necessary predicate to understanding meaning. ${ }^{398}$

After explaining that words have several meanings and often more than one even in a dictionary, Oliver Wendell Holmes reflected that "[y]ou have to consider the sentence in which it stands to decide which of those meanings it bears in the particular case, and very likely will see that it there has a shade of significance more refined than any given in the wordbook." 399 That conclusion comports with the admonition of John Locke: "Words having naturally no signification, the Idea which each stands for, must be learned and retained, by those who would exchange Thoughts, and hold intelligible Discourse with others in any Language." 400 Kemp Malone counseled that "[t]he meaning or meanings of a word are determined by usage. That is to say, if we want to know what a word means, we must find out by studying concrete cases in which the word is actually used by speakers and writers."

The Iqbal Court stated that "[d]etermining whether a complaint states a plausible claim for relief will ... be a context-specific task that requires the reviewing court to draw on its judicial experience and common sense."402 But the Court said nothing about what courts should do or where they should look to determine whether an allegation in a complaint is "conclusory." Ultimately, given the history and the limitations in dictionaries generally, discussed in the previous Parts, it would be misguided to attempt to find any authoritative guidance for the meaning of "conclusory" in the context of the Iqbal decision from dictionaries. The dictionary definition does not leave us with much to work with, and certainly cannot help litigators find an ascertainable standard in Iqbal to apply to future cases. We are left to wonder whether the use of a dictionary to interpret a term used but not defined by a court has any utility at all, and whether instead it obtains independent meaning only discernable from the text of the opinion in which it is placed.

\footnotetext{
${ }^{398}$ Randolph, supra note 397, at 74 ("[Dictionaries are] word zoos ... [where o]ne can observe an animal's features in the zoo, but one still cannot be sure how the animal will behave in its native surroundings.").

${ }^{399}$ Oliver Wendell Holmes, Jr., The Theory of Legal Interpretation, 12 HARV. L. REV. 417, 417 (1899).

400 John Locke, AN EsSAy CONCERning Human Understanding 307 (Pauline Phemister ed., Oxford Univ. Press 2008) (1690).

${ }^{401}$ Kemp Malone, On Defining Mahogany, 16 Language 308, 308 (1940).

${ }^{402}$ Ashcroft v. Iqbal, 556 U.S. 662, 129 S. Ct. 1937, 1950 (2009).
} 
Furthermore, all of the speculations on meaning and theories discussed in Part III do not provide a clear answer. But a search of past usages could test whether these speculations comport with prior use and help us further assess their validity.

All of this is not to say that "conclusory" lacks meaning. Nor does it mean that a meaning is impossible to discern. Instead, it only has a meaning with power when read in light of its surrounding usage and application. As an isolated word, it is useless to us. It is only a thing, and to take it as something more risks error and perpetuates confusion. In context it is more than a thing; it is an idea, and as John Locke explained, "We should have a great many fewer disputes in the world if words were taken for what they are, the signs of our ideas only, and not for things themselves." 403

Oliver Cromwell eloquently explained that we must look to the speaker or writer of words and the context in which they are used to give words power: "Words have not their import from the natural power of particular combinations of character, or from the real efficacy of certain sounds, but from the consent of those that use them, and arbitrarily annex certain ideas to them, which might have been signified with equal propriety by any other." ${ }^{404}$ Studying the use of the word "conclusory" in other court opinions - which define that "consent" of usage-is the place to look for the meaning of "conclusory" and the ideas "annexed" to that word in actual cases and controversies memorialized in the opinions in the law books.

Several commentators have noted that, by its nature, the conclusory standard in Iqbal and Twombly is necessarily context-dependent. ${ }^{405}$ Because of the standard's uncertainty and contextual dependence, there may be a long adjustment period for the lower courts before they fully grasp the meaning of "conclusory" in the pleading context. Some loathe this reality. Clermont and Yeazell, for example, have explained that "we can expect a long period, perhaps a decade or more, of sorting and jostling before we have even a slightly clearer idea about what allegations must appear in complaints." ${ }^{406}$ Moreover, they warn that "[p]ersistent

${ }^{403}$ LOCKE, supra note 400, at 317. See also McDowell, supra note 337, at 267 ("Both Hobbes and Locke looked upon language as purely conventional.").

${ }^{404}$ A New Dictionary of Quotations: On Historical Principles From AnCiEnT AND Modern SOURCES 357 (H.L. Mencken ed., 1991).

${ }^{405}$ Hartnett, supra note 72, at 492-93 ("What is 'conclusory' depends on the right of action on which the claimant seeks relief and the conclusions that are necessary to relief under that right of action."); Spencer, supra note 62, at 32 ("Many of the courts that have considered Twombly's standard have expressed the view that the case propounds a context-dependent approach to pleading, but have not always articulated specifically how context affects the level of facts that must be alleged.").

${ }^{406}$ Clermont \& Yeazell, supra note 61, at 846. 
U N I V E R S I T Y O F P I T T S B U R G H L A W R E V I E W

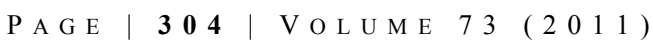

confusion on such a determinative feature contributes to major destabilization of civil litigation-destabilization created by the Court's invention of a new and jarring test, exaggerated by its unclear delivery, and intensified by the poor legal process the Court followed." ${ }^{407}$ That may be true, but litigants are forced to work within the system now and must work with what is available to attempt to curb the chaos.

The lower courts will serve as a laboratory in the coming years for defining "plausible" and "conclusory." ${ }^{\text {" } 08}$ Reference to previous experience is the best means for fleshing out pleading standards, yet the standards in Iqbal have a relatively small base of pre-existing samples to serve as precedent, to the extent that they constitute new requirements. ${ }^{409}$ A completely new database of cases will need to be created, but there are some things we can learn from the past.

If the dictionary is not the best place to start for understanding the meaning of "conclusory" in Iqbal, then a far better course of action is to analyze past usages of the term by the Supreme Court and other lower courts to find persuasive analogies to any case at hand. As demonstrated in Part I, the legal world is populated with a substantial body of usage examples for the word "conclusory." All of these should be mined as resources for analogy. Although the Supreme Court has not always used the word in the same context as it appeared in Iqbal, in many places it has, and that is a good place to start. After all, as one author has opined, "For the most part ... the members of the Supreme Court are our ultimate lexicographers when it comes to the meanings of legal words. " 410 Appendix E is intended to assist in that endeavor. It provides a reference list of U.S. Supreme Court cases that have used the term "conclusory," with minor annotation to indicate some context of the usage. Litigants and courts should reference these cases and search for the usage of the term in past contexts similar to any new case in which they are involved. It is an opportunity to assess by analogy.

Of course, one may also find more of the same know-it-when-they-see-it approach. Judges use "conclusory" when it is apt and reject it when it is inapt. The

\footnotetext{
${ }^{407} I d$.

${ }^{408} C f$. id. at 844-46 (explaining that it will take years to develop any sense of a standard or develop a corpus of precedent to make analogies for the plausibility requirement).

${ }^{409} \mathrm{Id}$. at 832 ("In seeking restabilizing guidance, one naturally looks to procedural experience for some help.").

${ }^{410}$ Solan, supra note 216 , at 51 .
} 
Court's own precedent might, in some ways, cloud the meaning of "conclusory" as much as it clarifies it. ${ }^{411}$

Some believe that Iqbal came "with little direction" and invited "weakly constrained judicial discretion." " Iqbal has been called loose and criticized for allowing "a disparate range of interpretations about what is conclusory and what is plausible." ${ }^{, 13}$ Mohan contends that "the arbitrariness inherent in Iqbal's new standard threatens to increase partiality in judicial decision making." ${ }^{, 414}$ Others contend that the role the judiciary is being asked to serve under Iqbal is nothing radical and, rather, is consistent with charges to the judiciary in other contexts. ${ }^{415}$ They argue that Iqbal did nothing extraordinary ${ }^{416}$ and was simply a means of setting a fair, effective balance; ${ }^{417}$ moreover, some argue even that a conclusory standard is already implicit in prior case law. ${ }^{418}$ The Iqbal Court itself claimed its decision was not revolutionary. ${ }^{419}$

Without clear guidance on the standards in Iqbal, including the meaning of "conclusory," inconsistencies in application are likely, if not inevitable. ${ }^{420}$

${ }^{411}$ Hatamyar, supra note 66, at 573, 569 n.107 (discussing Erickson v. Pardus, 551 U.S. 89 (2007), where the Court, citing Twombly, vacated the Tenth Circuit's dismissal on the grounds that the allegations were conclusory and held that the lower court departed "in so stark a manner from the pleading standard mandated by the Federal Rules of Civil Procedure").

${ }^{412}$ Mohan, supra note 75, at 1196.

${ }^{413}$ Id. at 1197 ("[T]he brief experience with Iqbal in the lower courts thus far illustrates this arbitrariness.").

${ }^{414} I d$. at 1199.

${ }^{415}$ Hartnett, supra note 72, at 498 (the call to use experience and common sense in deciding plausibility is "not radical").

${ }^{416}$ Schwartz \& Appel, supra note 65, at 1140 ("The Court in Twombly and Iqbal simply resolved to breathe new life into what was an underenforced and arguably misunderstood aspect of judges' gatekeeping role, and to attach a meaningful label to this standard so that judges could more readily provide a legal basis for dismissing an insufficient pleading.").

${ }^{417}$ Id. at 1143-44 (dismissing Iqbal's critics) ("The Supreme Court interpreted the Federal Rules in Twombly and Iqbal with the purpose of reaching the most fair and effective balance of varying policy interests.").

${ }^{418} I d$. at $1140 \mathrm{n} .168$ (providing examples of pre-Twombly cases that rejected conclusory pleadings).

419 Hatamyar, supra note 66, at 579 ("Far from acknowledging that the so-called 'two-pronged approach' constitutes a radical change, the Court implied that Twombly had explicitly and intentionally applied this 'approach."').

${ }^{420}$ Mohan, supra note 75, at 1201 ("In light of the unpredictable nature of the Iqbal standard . . there is little reason to believe courts will consistently reach the right outcome. A discretionary system might 
Distinguishing conclusion from fact is a difficult task and introduces problematic issues of subjectivity. ${ }^{421}$ The test may be incapable of consistent or objective application. But again, past case law is probably the best data set available to try to find, or enforce, some consistency.

The case method and reasoning by analogy may be the only means to develop any standard for ascertaining what "conclusory" means. Such a process is, of course, not unknown to law and is, in fact, one of the unique and respected means for the development of law, accounting for flexibility and evolution in our common-law system. ${ }^{422}$ Courts will need to labor at it. ${ }^{423}$ As Clermont and Yeazell point out, "Insisting on nonconclusory statements and then testing for a reasonable inference constitutes a method not unknown at law, but doing so based on a bare pleading is revolutionary., ${ }^{, 24}$

Given this lack of guidance on the meaning of the "conclusory" standard from the Court in Iqbal, available scholarship, and dictionary definitions, there are two primary conclusions: (1) the Iqbal conclusory prong has a low degree of predictability in its application and is largely subject to judicial interpretation of pleadings on a highly individualized, judge-specific, and case-by-case basis; and (2) one of the only methods available to operate within this high degree of uncertainty is to base one's understanding of the Iqbal test on the historical usages of the word (from the available usages charted in Part I) within past court decisions and elsewhere, analyzing whether an allegation is conclusory or nonconclusory through analogical reasoning to previous cases, using the same terms in similar contexts.

It remains questionable whether the Iqbal test provides anything approaching a workable standard, even with a data set of potentially analogous uses of the term

have achieved some level of consistency had the Supreme Court provided judges with factors to guide that discretion.").

${ }^{421}$ Hatamyar, supra note 66, at 565-66 ("[There is a] near-impossibility of distinguishing 'conclusion' from 'fact' ... [t]he problem is that one person's 'conclusion' is another person's fact.").

${ }^{422}$ See generally Edward H. Levi, An InTROduction to Legal ReAsoning (1947); Cass Sunstein, Analogical Reasoning, 106 HARV. L. REV. 741 (1993).

${ }^{423}$ Clermont \& Yeazell, supra note 61, at 841 ("The courts must put in the work to divine the meaning of the new test's two steps.").

${ }^{424}$ Id. at 834 . See also Reinert, supra note 12, at 131 ("In and of itself, this was not new; what was new was the Court's holding that allegations of state of mind, despite the explicit language of Rule 9(b), must be alleged with some factual detail."); Steinman, supra note 63, at $1319 \mathrm{n} .150$ (listing a sampling of pre-Twombly cases using a "conclusory"-based test). 
"conclusory" to draw from. Given that the cases where a "conclusory" modifier has been used, as a whole, reflect the same type of interpretive and subjective division witnessed between the majority and dissent in the Iqbal decision itself, the first prong of Iqbal will likely remain unpredictable as currently stated. Thus, we return to the possibility of being faced with a know-it-when-they-see-it standard. ${ }^{425}$ Some further clarification from the Court will be necessary before litigants can be confident in the sufficiency of their pleadings to withstand dismissal. Until there is some more concrete and understandable guidance on the first prong of Iqbal, the meaning of "conclusory" in that case will remain quite elusory to all those involved in civil litigation.

\section{CONCLUSION}

According to one scholar, the "definitional ambiguity of 'conclusory' ... has plagued the profession for at least a century. ${ }^{, 426}$ Indeed, that is true, as this history confirms. Iqbal just compounds that plague and makes it more visible today.

"Conclusory" is a wonderful word. Whether it is fit to be a discernable standard is another question. At best, it seems, "conclusory" sets a standard that requires a certain degree of case-by-case, contextual analysis. Whether the level of indeterminacy is acceptable is a separate question. What is clear is that there is no clear meaning of "conclusory" ascertainable from dictionaries as it is to be applied in the pleading context. Neither the cases nor the commentary provides much more than the general meaning of nothing more than a mere conclusion."

Thus, while its presence is effusive in the law and has been for decades, "conclusory" remains a word with a meaning that is elusive. As it obtains greater utility and increased traction in the law, "conclusory" is, in some ways, becoming even more difficult to define than ever.

${ }^{425}$ Brown discusses a similar problem with the plausibility prong:

A judge, and the Supreme Court, "could never succeed in intelligibly" defining the line between speculative and plausible, but I think that most judges will "know it when [they] see it." I pause here to point out that excepting the disagreement on the conclusory nature of several of the allegations, there was surprising uniformity in the Justices' interpretation of the plausibility inquiry in Twombly (a 7-2 decision) and Iqbal (9-0).

Brown, supra note 72, at 1296.

${ }^{426}$ Hatamyar, supra note 66, at 580. 
U N I V E R S I T Y O F P I T T S B U R G H L A W R E V I E W

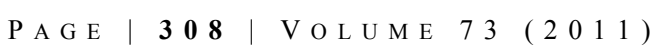

Appendix A

Google Books NGram Viewer Results for "Conclusory," "Conclusional," and "Conclusionary"

Table 1A

Graph "Conclusory" from 1700 to 2008 from the Corpus of English with a Smoothing of 3

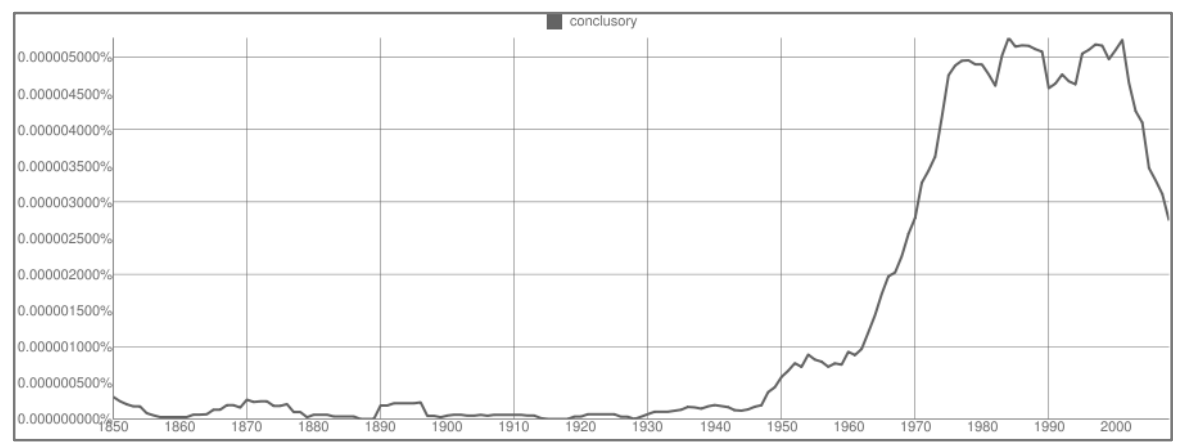

Table 2A

Graph "Conclusory," "Conclusional" from 1700 to 2008 from the Corpus of English with a Smoothing of 3

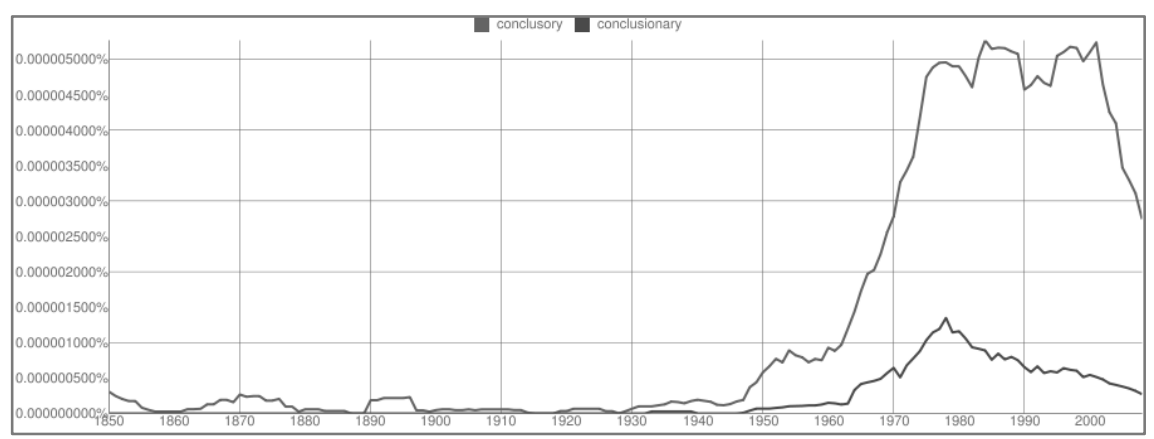


While E F F U IVE, “C ONCLUSORY” IS S T I L L E L U S IVE

\begin{tabular}{l|l}
$P$ A G E & 309
\end{tabular}

Table 3A

Graph "Conclusory," "Conclusionary" from 1700 to 2008 from the Corpus of English with a Smoothing of 3

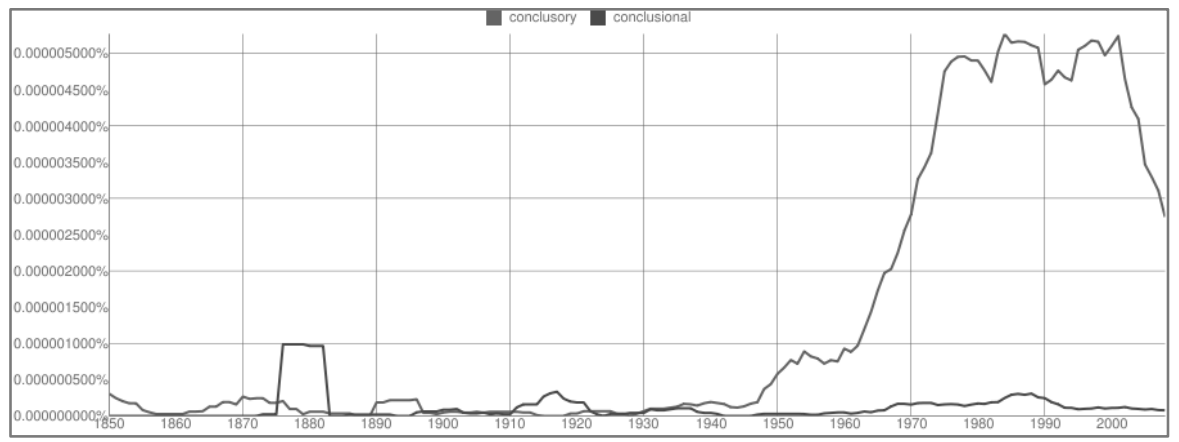

Source for Tables 1A, 2A and 3A: GOOGLE BoOKS N-GRAM VIEWER, http://books.google.com/ngrams (last visited May 28, 2012) (based on the model and database developed by Jean-Baptiste Michel et al., Quantitative Analysis of Culture Using Millions of Digitized Books, 331 SCI., Jan. 14, 2011). 
U N I V E R S I T Y O F P I T T S B U R G H L A W R E V I E W

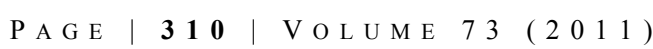

\section{Appendix B}

Number of Federal and State Court Case Opinions with Occurrence of the Word "Conclusory" Reported in Westlaw's ALLCASES Database By 5-Year Periods, 1901-2010

\begin{tabular}{|c|c|}
\hline Years & No. of Opinions \\
\hline $1901-1905$ & 0 \\
\hline $1906-1910$ & 1 \\
\hline $1911-1915$ & 0 \\
\hline $1916-1920$ & 1 \\
\hline $1921-1925$ & 6 \\
\hline $1926-1930$ & 5 \\
\hline $1931-1935$ & 14 \\
\hline $1936-1940$ & 37 \\
\hline $1941-1945$ & 107 \\
\hline $1946-1950$ & 160 \\
\hline $1951-1955$ & 244 \\
\hline $1956-1960$ & 512 \\
\hline $1961-1965$ & 829 \\
\hline $1966-1970$ & 1453 \\
\hline $1971-1975$ & 2665 \\
\hline $1976-1980$ & 4352 \\
\hline $1981-1985$ & 7113 \\
\hline $1986-1990$ & 12103 \\
\hline $1991-1995$ & 17551 \\
\hline $1996-2000$ & 24658 \\
\hline $2001-2005$ & 35803 \\
\hline $2006-2010$ & 90004 \\
\hline
\end{tabular}

*Data compiled, 2011, by Donald J. Kochan, from search for conclusory in ALLCASES database in Westlaw. 


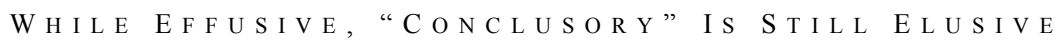

\section{Appendix C}

Number of Federal and State Court Case Opinions with Occurrence of the Word "Conclusory" Reported in Westlaw's ALLCASES Database By Year, 1901-2011

\begin{tabular}{|l|l|}
\hline YEAR & $\begin{array}{l}\text { No. of } \\
\text { Opinions }\end{array}$ \\
\hline 1901 & 0 \\
\hline 1902 & 0 \\
\hline 1903 & 0 \\
\hline 1904 & 0 \\
\hline 1905 & 0 \\
\hline 1906 & 0 \\
\hline 1907 & 0 \\
\hline 1908 & 1 \\
\hline 1909 & 0 \\
\hline 1910 & 0 \\
\hline 1911 & 0 \\
\hline 1912 & 0 \\
\hline 1913 & 0 \\
\hline 1914 & 0 \\
\hline 1915 & 0 \\
\hline 1916 & 1 \\
\hline 1917 & 0 \\
\hline 1918 & 0 \\
\hline 1919 & 0 \\
\hline 1920 & 0 \\
\hline 1921 & 0 \\
\hline 1922 & 0 \\
\hline 1923 & 2 \\
\hline 1924 & 1 \\
\hline 1925 & 3 \\
\hline 1926 & 0 \\
\hline 1927 & 0 \\
\hline 1928 & 2 \\
\hline 1929 & 1 \\
\hline 1930 & 2 \\
\hline 1931 & 6 \\
\hline 1932 & 2 \\
\hline 1933 & 0 \\
\hline 1934 & 4 \\
\hline 1935 & 2 \\
\hline 1936 & 3 \\
\hline 1937 & 5 \\
\hline 1938 & 8 \\
\hline 1939 & 14 \\
\hline 1940 & 7 \\
\hline & \\
\hline
\end{tabular}

\begin{tabular}{|l|l|}
\hline YEAR & $\begin{array}{l}\text { Noof of } \\
\text { Opinions }\end{array}$ \\
\hline 1941 & 12 \\
\hline 1942 & 17 \\
\hline 1943 & 29 \\
\hline 1944 & 21 \\
\hline 1945 & 28 \\
\hline 1946 & 32 \\
\hline 1947 & 34 \\
\hline 1948 & 32 \\
\hline 1949 & 34 \\
\hline 1950 & 28 \\
\hline 1951 & 38 \\
\hline 1952 & 41 \\
\hline 1953 & 49 \\
\hline 1954 & 51 \\
\hline 1955 & 65 \\
\hline 1956 & 83 \\
\hline 1957 & 98 \\
\hline 1958 & 84 \\
\hline 1959 & 117 \\
\hline 1960 & 130 \\
\hline 1961 & 157 \\
\hline 1962 & 170 \\
\hline 1963 & 134 \\
\hline 1964 & 180 \\
\hline 1965 & 188 \\
\hline 1966 & 213 \\
\hline 1967 & 258 \\
\hline 1968 & 275 \\
\hline 1969 & 326 \\
\hline 1970 & 381 \\
\hline 1971 & 456 \\
\hline 1972 & 461 \\
\hline 1973 & 523 \\
\hline 1974 & 569 \\
\hline 1975 & 656 \\
\hline 1976 & 743 \\
\hline 1977 & 787 \\
\hline 1978 & 832 \\
\hline 1979 & 915 \\
\hline 1980 & 1075 \\
\hline & \\
\hline
\end{tabular}

\begin{tabular}{|l|l|}
\hline YEAR & $\begin{array}{l}\text { No: of } \\
\text { Opinions }\end{array}$ \\
\hline 1981 & 1151 \\
\hline 1982 & 1248 \\
\hline 1983 & 1336 \\
\hline 1984 & 1508 \\
\hline 1985 & 1870 \\
\hline 1986 & 2269 \\
\hline 1987 & 2233 \\
\hline 1988 & 2363 \\
\hline 1989 & 2557 \\
\hline 1990 & 2681 \\
\hline 1991 & 2805 \\
\hline 1992 & 3266 \\
\hline 1993 & 3534 \\
\hline 1994 & 3816 \\
\hline 1995 & 4130 \\
\hline 1996 & 4525 \\
\hline 1997 & 4645 \\
\hline 1998 & 5121 \\
\hline 1999 & 5243 \\
\hline 2000 & 5324 \\
\hline 2001 & 5951 \\
\hline 2002 & 6303 \\
\hline 2003 & 6571 \\
\hline 2004 & 7098 \\
\hline 2005 & 9880 \\
\hline 2006 & 13609 \\
\hline 2007 & 15604 \\
\hline 2008 & 16714 \\
\hline 2009 & 20319 \\
\hline 2010 & 23758 \\
\hline 2011 & 26033 \\
\hline & \\
\hline
\end{tabular}

*Data compiled, 2011, by Donald J. Kochan, from search for conclusory in ALLCASES database in Westlaw. 
U N I V E R S I T Y O F P I T T S B U R G H L A W R E V I E W

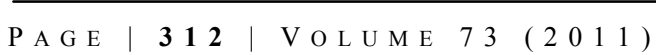

\section{Appendix D}

Number of U.S. Supreme Court Case Opinions with Occurrence of the Word "Conclusory" Reported in Westlaw's SCt Database by Year, 1942-2011

\begin{tabular}{|c|c|}
\hline YEAR & $\begin{array}{l}\text { No. of } \\
\text { Opinions }\end{array}$ \\
\hline 1942 & 1 \\
\hline 1943 & 1 \\
\hline 1944 & 0 \\
\hline 1945 & 0 \\
\hline 1946 & 0 \\
\hline 1947 & 0 \\
\hline 1948 & 0 \\
\hline 1949 & 0 \\
\hline 1950 & 0 \\
\hline 1951 & 0 \\
\hline 1952 & 1 \\
\hline 1953 & 1 \\
\hline 1954 & 0 \\
\hline 1955 & 1 \\
\hline 1956 & 1 \\
\hline 1957 & 1 \\
\hline 1958 & 1 \\
\hline 1959 & 2 \\
\hline 1960 & 3 \\
\hline 1961 & 6 \\
\hline 1962 & 2 \\
\hline 1963 & 3 \\
\hline 1964 & 5 \\
\hline 1965 & 3 \\
\hline
\end{tabular}

\begin{tabular}{|c|c|}
\hline YEAR & $\begin{array}{l}\text { No. of } \\
\text { Opinions }\end{array}$ \\
\hline 1966 & 2 \\
\hline 1967 & 3 \\
\hline 1968 & 5 \\
\hline 1969 & 3 \\
\hline 1970 & 6 \\
\hline 1971 & 9 \\
\hline 1972 & 9 \\
\hline 1973 & 7 \\
\hline 1974 & 8 \\
\hline 1975 & 7 \\
\hline 1976 & 8 \\
\hline 1977 & 9 \\
\hline 1978 & 7 \\
\hline 1979 & 7 \\
\hline 1980 & 6 \\
\hline 1981 & 7 \\
\hline 1982 & 10 \\
\hline 1983 & 7 \\
\hline 1984 & 6 \\
\hline 1985 & 10 \\
\hline 1986 & 10 \\
\hline 1987 & 3 \\
\hline 1988 & 6 \\
\hline 1989 & 6 \\
\hline
\end{tabular}

\begin{tabular}{|l|l|}
\hline YEAR & $\begin{array}{l}\text { No. of } \\
\text { Opinions }\end{array}$ \\
\hline 1990 & 9 \\
\hline 1991 & 7 \\
\hline 1992 & 4 \\
\hline 1993 & 5 \\
\hline 1994 & 1 \\
\hline 1995 & 3 \\
\hline 1996 & 2 \\
\hline 1997 & 6 \\
\hline 1998 & 2 \\
\hline 1999 & 1 \\
\hline 2000 & 7 \\
\hline 2001 & 3 \\
\hline 2002 & 4 \\
\hline 2003 & 4 \\
\hline 2004 & 3 \\
\hline 2005 & 3 \\
\hline 2006 & 2 \\
\hline 2007 & 9 \\
\hline 2008 & 3 \\
\hline 2009 & 4 \\
\hline 2010 & 4 \\
\hline 2011 & 2 \\
\hline
\end{tabular}

*Data compiled, 2011, by Donald J. Kochan, from search for conclusory in SCT database in Westlaw. 


\section{Appendix E}

\section{Supreme Court Opinions with Occurrence of the Words "Conclusory" or "Nonconclusory": Citations with Information Regarding Each Occurrence Including Justice Authoring Opinion, Type of Opinion, and Surrounding Words Indicating Context of Usage ${ }^{427}$ \\ (1942-2011)}

Cullen v. Pinholster, 131 S. Ct. 1388 (2011).

- "conclusory allegations," p. 1403 n.12 (Thomas, J., majority).

Felkner v. Jackson, 131 S. Ct. 1305 (2011).

- “conclusory explanation,” p. 1307 (per curiam).

*Skilling v. United States, 130 S. Ct. 2896 (2010).

- " "questions were conclusory," p. 2903 (Ginsburg, J., majority) (reciting Skilling's argument).

- "court's questions were conclusory,” p. 2918 (Ginsburg, J., majority) (quoting Skilling's argument).

Holland v. Florida, 130 S. Ct. 2549 (2010).

- " conclusory formulation," p. 2566 (Scalia, J., majority).

- "conclusory allegation," p. 2573 n.8 (Scalia, J., majority).

${ }^{427}$ Data compiled, 2011, by Donald J. Kochan, from search for ("conclusory" or "nonconclusory" or "non-conclusory") in the SCT database in Westlaw. Research assistance in the drafting and creation of Appendix E provided by Jessica Travis, J.D. expected 2011, Chapman University School of Law.

*Note that 6 of these cases use the word "conclusory" only when quoting from a party's argument or when quoting a lower court opinion in the same case for purposes of background to the case only. These cases are marked by an asterisk (“*”).

** Note that running the search ("conclusory" or "nonconclusory" or "nonconclusory") in Westlaw's SCT database retrieves 283 documents (as of Nov. 22, 2011). Upon further review, two of these retrievals have the word "conclusory" only in the reporter's summary or headnotes. See City of Richmond v. J.A. Croson Co., 488 U.S. 469 (1989) ("highly conclusory" ("Conclusory" only appears in the Syllabus; note the word "conclusionary" is used in text of opinion)); T.I.M.E. Inc. v. United States, 359 U.S. 454 (1959) ("conclusory attention" (only appearing in a headnote)). Those cases have not been included in this list. Only cases where the word is used in the text of a Justice's or a per curiam opinion are included. 
U N I V E R S I T Y O F P I T T S B U R G H L A W R E V I E W

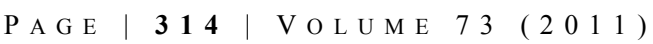

*Hardt v. Reliance Standard Life Ins. Co., 130 S. Ct. 2149 (2010).

- "medical conclusions ... extremely vague and conclusory," p. 2154 (Thomas, J., majority) (quoting the district court) (internal quotation marks omitted).

Ashcroft v. Iqbal, 556 U.S. 662 (2009).

- “conclusory statements," p. 663 (Kennedy, J., majority).

- " “nonconclusory factual allegation,” p. 680 (Kennedy, J., majority).

- " “allegations are conclusory,” p. 681 (Kennedy, J., majority).

- “conclusory nature,” p. 681 (Kennedy, J., majority).

- “conclusory allegation,” p. 686 (Kennedy, J., majority).

- “conclusory statements,” p. 686 (Kennedy, J., majority).

- “conclusory allegation,” p. 689 (Souter, J., dissenting).

- "Iqbal's allegations against them (which they call conclusory)," p. 690 (Souter, J., dissenting) (quoting the district court).

- "conclusory," p. 694 (Souter, J., dissenting) (quoting the majority opinion).

- “Ashcroft and Mueller as conclusory,” p. 697 (Souter, J., dissenting).

- "nonconclusory statements,” p. 697 (Souter, J., dissenting).

- " "allegations singled out by the majority as "conclusory," p. 698 (Souter, J., dissenting) (quoting the majority opinion).

- “statements it selects are conclusory," p. 699 (Souter, J., dissenting).

- "allegations in the complaint as nonconclusory," p. 699 (Souter, J., dissenting).

- " "allegations are not conclusory," p. 699 (Souter, J., dissenting).

- “majority deems it merely conclusory,” p. 699 (Souter, J., dissenting).

Presley v. Georgia, 130 S. Ct. 721 (2010).

- "conclusory assertion," p. 725 (per curiam) (citing Press-Enterprise Co. v. Superior Court of Cal., County of Riverside, 478 U.S. 1, 15 (1986)).

Cone v. Bell, 556 U.S. 449 (2009).

- " conclusory arguments," p. 490 (Thomas, J., dissenting) (quoting Cone v. Bell, 492 F.3d 743, 755 (6th Cir. 2007)).

Arizona v. Gant, 556 U.S. 332 (2009).

- “Justice Alito's conclusory assertion," pp. 353-54 (Scalia, J., concurring).

Negusie v. Holder, 555 U.S. 511 (2009).

- “conclusory pronouncement,” p. 549 n.3 (Thomas, J., dissenting).

Walker v. Georgia, 129 S. Ct. 453 (2008).

- “conclusory terms," p. 455 (statement of Stevens, J.) (cert. denied).

- " conclusory review," p. 456 n.3 (statement of Stevens, J.) (cert. denied). 


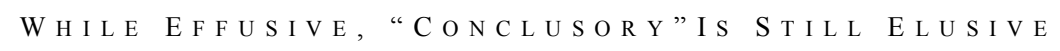

\begin{tabular}{l|lll}
$P$ A G E & $\mathbf{3} 1 \mathbf{5}$
\end{tabular}

Kennedy v. Louisiana, 554 U.S. 407 (2008).

- "conclusory references," p. 469 (Alito, J., dissenting).

Rothgery v. Gillespie Cnty., Tex., 554 U.S. 191 (2008).

- "conclusory observations," p. 229 (Thomas, J., dissenting).

Parents Involved in Comty. Schs. v. Seattle School Dist. No. 1, 551 U.S. 701 (2007).

- “conclusory argument,” p. 733 (Roberts, J., majority).

Erickson v. Pardus, 551 U.S. 89 (2007).

- "allegations, and others to be noted, to be "conclusory," p. 90 (per curiam) (quoting the Tenth Circuit).

- conclusory allegations," p. 92 (per curiam) (quoting magistrate judge).

- "the allegations in question, concerning harm caused petitioner by the termination of his medication, were too conclusory," p. 93 (per curiam).

- "petitioner's allegations of harm were too conclusory," p. 94 (per curiam).

Utrecht v. Brown, 551 U.S. 1 (2007).

- " conclusory statement," p. 38 (Stevens, J., dissenting).

Bell Atl. Corp. v. Twombly, 550 U.S. 544 (2007).

- " conclusory allegation," p. 557 (Souter, J., majority).

- "line between the conclusory and the factual," p. 557 n.5 (Souter, J., majority).

- “conclusory statement," p. 561 (Souter, J., majority).

- " "plaintiffs' conclusory allegations," p. 565 n.10 (Souter, J., majority).

- $\quad$ "conclusory terms," p. 583 (Stevens, J., dissenting) (quoting Krause v. Rhodes, 471 F.2d 430, 433 (CA6 1972)).

- "complaint is 'conclusory,"” p. 590 (Stevens, J., dissenting) (quoting Brownlee v. Conine, 957 F.2d 353, 354 (CA7 1992)).

- "conclusory" allegation, p. 593 n.12 (Stevens, J., dissenting) (quoting majority opinion).

Roper v. Weaver, 550 U.S. 598 (2007).

- " conclusory assertion," p. 607 (Scalia, J., dissenting).

KSR Int'l Co. v. Teleflex Inc., 550 U.S. 398 (2007).

- “conclusory statements," p. 418 (Kennedy, J., majority).

- " conclusory contention," p. 423 (Kennedy, J., majority).

- “conclusory affidavit,” p. 426 (Kennedy, J., majority).

Envtl. Defense v. Duke Energy Corp., 549 U.S. 561 (2007).

- cconclusory statement," p. 580 (Souter, J., majority). 
U N I V E R S I T Y O F P I T T S B U R G H L A W R E V I E W

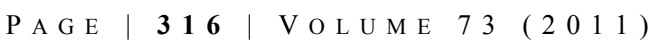

Massachusetts v. EPA, 549 U.S. 497 (2007).

- "petitioners' submissions as 'conclusory,", p. 523 n.21 (Stevens, J., majority) (quoting the dissent).

- " conclusory statement," p. 542 (Roberts, J., dissenting).

- “declarations' conclusory (not to say fanciful) statements,” p. 546 (Roberts, J., dissenting).

MedImmune, Inc. v. Genentech, Inc., 549 U.S. 118 (2007).

- "conclusory assertion," p. 131 n.10 (Scalia, J., majority) (quoting Electrical Fittings Corp. v. Thomas \& Betts Co., 307 U.S. 241 (1939)).

Beard v. Banks, 548 U.S. 521 (2006).

- $\quad$ "documented reason for censoring [a magazine] is too conclusory ..." p. 554 (Ginsburg, J., dissenting) (quoting Murphy v. Missouri Dept. of Corrections, 372 F.3d 979, 986 (CA8 2004)).

Gonzales v. Oregon, 546 U.S. 243 (2006).

- “conclusory assertion,” p. 297 (Scalia, J., dissenting).

Doe v. Gonzales, 546 U.S. 1301 (2005).

- "conclusory statements," p. 1305 (Ginsburg, J., majority).

Wilkinson v. Austin, 545 U.S. 209 (2005).

- "statement shall "not use conclusory . .." p. 220 (Kennedy, J., majority) (quoting Austin v. Wilkinson, 204 F. Supp. 2d 1024, 1027 (N.D. Ohio 2002)).

Gonzales v. Raich, 545 U.S. 1 (2005).

- " conclusory statements," p. 57 (O’Connor, J., dissenting).

Tennessee v. Lane, 541 U.S. 509 (2004).

- “conclusory sentence,” p. 545 (Rehnquist, J., dissenting).

- “conclusory statements,” p. 546 (Rehnquist, J., dissenting).

Banks v. Dretke, 540 U.S. 668 (2004).

- "conclusory and uncorroborated claims," p. 710 (Thomas, J., dissenting).

Doe v. Chao, 540 U.S. 614 (2004).

- “conclusory allegations,” p. 617 (Souter, J., majority).

Virginia v. Maryland, 540 U.S. 56 (2003).

- “conclusory position,” p. 90 (Kennedy, J., dissenting).

Mitchell v. Esparza, 540 U.S. 12 (2003).

- “conclusory opinion," p. 14 (per curiam). 


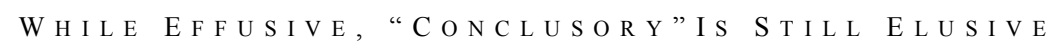

\begin{tabular}{l|lll} 
P A G E & 31 & 1
\end{tabular}

Lawrence v. Texas, 539 U.S. 558 (2003).

- “conclusory statement," p. 601 (Scalia, J., dissenting).

Grutter v. Bollinger, 539 U.S. 306 (2003).

- “conclusory statement," p. 356 (Thomas, J., dissenting).

Barnhardt v. Peabody Coal Co., 537 U.S. 149 (2003).

- "Justice SCALIA's closest approach to a nonconclusory justification for his position," p. 159 n.6 (Souter, J., majority).

New York v. FERC, 535 U.S. 1 (2002).

- "conclusory statement" p. 30 (Thomas, J., dissenting).

- " "FERC's conclusory statement," p. 31 (Thomas, J., dissenting).

- " "FERC's conclusory statement," p. 34 (Thomas, J., dissenting).

- " "FERC's conclusory statement," p. 35 (Thomas, J., dissenting)

Swierkiewicz v. Sorema N.A., 534 U.S. 506 (2002).

- “conclusory allegations," p. 514 (Thomas, J., majority).

Barnhart v. Sigmon Coal Co., 534 U.S. 438 (2002).

- "conclusory assertion," p. 459 fn.17 (Thomas, J., majority).

- "conclusory assertion," p. 459 fn.17 (Thomas, J., majority) (second appearance).

Lee v. Kemna, 534 U.S. 362 (2002).

- “conclusory paragraph,” p. 397 (Kennedy, J., dissenting).

Lorillard Tobacco Co. v. Reilly, 533 U.S. 525 (2001).

- "conclusory assertion," p. 583 (Thomas, J., concurring in part and concurring in the judgment).

United States v. Mead Corp., 533 U.S. 218 (2001).

- “conclusory references,” p. 238 n.19 (Souter, J., majority).

Dep't of Interior v. Klamath Water Users Protective Ass'n, 532 U.S. 1 (2001).

- "conclusory term," p. 12 (Souter, J., majority).

Mitchell v. Helms, 530 U.S. 793 (2000).

- " conclusory label," p. 877 (Souter, J., dissenting).

- "conclusory term," p. 882 (Souter, J., dissenting).

- “term was conclusory," p. 883 (Souter, J., dissenting).

Boy Scouts of Am. v. Dale, 530 U.S. 640 (2000).

- "conclusory words," p. 698 n.25 (Stevens, J., dissenting) (quoting Wooley v. Maynard, 430 U.S. 705, 721 (1977)).

Carter v. United States, 530 U.S. 255 (2000).

- “conclusory statement," p. 287 (Ginsburg, J., dissenting). 
U N I V E R S I T Y O F P I T T S B U R G H L A W R E V I E W

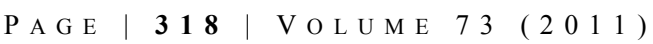

Avis Rent A Car Sys., Inc. v. Aguilar, 529 U.S. 1138 (2000).

- “conclusory nature," p. 1144 (Thomas, J., dissenting).

United States. v. Playboy Entm't Grp., 529 U.S. 803 (2000).

- " "conclusory statement," p. 822 (Kennedy, J., majority).

- “conclusory statements," p. 822 (Kennedy, J., majority) (quoting Sable Communications v. FCC, 492 U.S. 115, 129 (1989)).

Smith v. Robbins, 528 U.S. 259 (2000).

- “conclusory letter," p. 264 (Thomas, J., majority).

- " conclusory statement," p. 298 (Souter, J., dissenting).

- " conclusory certification," p. 298 n.5 (Souter, J., dissenting).

- “conclusory declaration,” p. 298 (Souter, J., dissenting).

Friends of the Earth, Inc. v. Laidlaw Envtl. Servs., Inc., 528 U.S. 167 (2000).

- "conclusory allegations," p. 184 (Ginsburg, J., majority) (quoting Lujan v. National Wildlife Federation, 497 U.S. 871, 888 (1990)).

- "conclusory allegations of an affidavit," p. 201 (Scalia, J., dissenting) (quoting Lujan v. National Wildlife Federation, 497 U.S. 871, 888 (1990)).

Richardson v. United States, 526 U.S. 813 (1999).

- “conclusory assertion," p. 830 (Kennedy, J., dissenting).

Nat'l Endowment for the Arts v. Finley, 524 U.S. 569 (1998).

- "legislature's conclusory belief," p. 604 n.3 (Souter, J., dissenting).

Crawford-El v. Briton, 523 U.S. 574 (1998).

- "nonconclusory factual allegations," p. 598 (Stevens, J., majority) (quoting Siegert v. Gilley, 500 U.S. 226, 236 (1991)).

Allentown Mack Sales and Services, Inc. v. NLRB, 522 U.S. 359 (1998).

- $\quad$ "The phrase 'so much . . . as to render the poll meaningless' is of course conclusory,” p. 366 n.1 (Scalia, J., majority).

- "conclusory statement," p. 394 (Breyer, J., concurring in part and dissenting in part).

Reno v. ACLU, 521 U.S. 844 (1997).

- "conclusory statements," p. 876 n.41 (Stevens, J., majority) (quoting Sable Communications of California, Inc. v. FCC, 492 U.S. 115, 129 (1989)).

Suitum v. Tahoe Reg'l Planning Agency, 520 U.S. 725 (1997).

- "conclusory allegation," p. 738. 


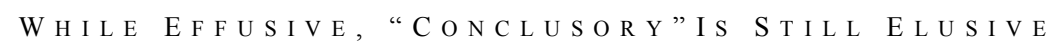

\begin{tabular}{l|ll} 
P A G E & 319
\end{tabular}

Camps Newfound/Owatonna, Inc. v. Town of Harrison, Me., 520 U.S. 564 (1997).

- "arbitrary, conclusory, and irreconcilable ..." p. 611 n.4 (Thomas, J., dissenting) (quoting D. CuRrie, The Constitution in the Supreme COURT: THE FIRST HundRED YEARS 1789-1888, at 234 (1985)).

Johnson v. United States, 520 U.S. 461 (1997).

- “conclusory sentence," p. 470 n.2 (Rehnquist, J., majority).

In re Vey, 520 U.S. 303 (1997).

- "conclusory statements," p. 303 (per curiam).

Turner Broad. Sys., Inc. v. FCC, 520 U.S 180 (1997).

- "conclusory argumentation," p. 224 (Kennedy, J., majority).

Carlisle v. United States, 517 U.S. 416 (1996).

- “conclusory assertions," p. 444 (Stevens, J., dissenting).

Holly Farms Corp. v. NLRB, 517 U.S. 392 (1996).

- “conclusory remark," p. 410 (O’Connor, J., concurring in part and dissenting in part).

Fla. Bar v. Went For It, Inc., 515 U.S. 618 (1995).

- “conclusory assertion,” p. 628 (O’Connor, J., majority).

*Missouri v. Jenkins, 515 U.S. 70 (1995).

- “conclusory rejection," p. 81 (Rehnquist, J., majority) (quoting the appellate court, Jenkins by Agyei v. Missouri, 11 F.3d 755 (8th Cir. 1993)).

United States. v. Lopez, 514 U.S. 549 (1995).

- " conclusory level," p. 612 n.2 (Souter, J., dissenting).

Dolan v. City of Tigard, 512 U.S. 374 (1994).

- “conclusory statement," p. 396 (Rehnquist, J., majority).

United States. v. Dixon, 509 U.S. 688 (1994).

- “cconclusory' fashion,” p. 700 n.4 (Scalia, J., majority) (quoting White, J., post at 721).

- "conclusory fashion," p. 721 (White, J., concurring in part and dissenting in part).

TXO Prod. Corp. v. Alliance Res. Corp., 509 U.S 443 (1993).

- “conclusory sentences," p. 498 (O’Connor, J., dissenting).

Gilmore v. Taylor, 508 U.S. 333 (1993).

- "conclusory rhetoric," p. 365 n.5 (Blackmun, J., dissenting).

U.S. Dep't of Justice v. Landano, 508 U.S. 165 (1993).

- " "suggestion is conclusory,” p. 176 (O’Connor, J., majority). 
U N I V E R S I T Y O F P I T T S B U R G H L A W R E V I E W

PAGE

Edenfield v. Fane, 507 U.S. 761 (1993).

- “conclusory statements," p. 771 (Kennedy, J., majority).

Lucas v. S.C. Coastal Council, 505 U.S. 1003 (1992).

- “conclusory assertion,” p. 1031 (Scalia, J., majority).

Planned Parenthood v. Casey, 505 U.S. 833 (1992).

- " "fact is undeveloped and totally conclusory," p. 956 (Rehnquist, J., concurring in part and dissenting in part).

- "not much less conclusory," p. 983 n.2 (Scalia, J., concurring in part and dissenting in part).

- "conclusory assertion," p. 990 n.5 (Scalia, J., concurring in part and dissenting in part).

Gade v. Nat'l Solid Wastes Mgmt. Ass'n, 505 U.S. 88 (1992).

- "conclusory statement," p. 110 (Kennedy, J., concurring in part and concurring in the judgment).

Burson v. Freeman, 504 U.S. 191 (1992).

- " conclusory label," p. 214 (Scalia, J., concurring in the judgment).

Virginia Bankshares, Inc. v. Sandberg, 501 U.S. 1083 (1991).

- “conclusory or qualitative terms," p. 1087 (Souter, J., majority).

- "conclusory in form," id. (Souter, J., majority).

- “conclusory terms," p. 1093 (Souter, J., majority).

- "conclusory commercial judgment," id. (Souter, J., majority).

- “conclusory the directors' statement," p. 1094 (Souter, J., majority).

- “conclusory adjective 'substantial,"” p. 1095 (Souter, J., majority).

- “conclusory terms,” p. 1095 (Souter, J., majority).

Schad v. Arizona, 501 U.S. 624 (1991).

- " “simply too conclusory,” p. 635 (Souter, J., majority).

Renne v. Geary, 501 U.S. 312 (1991).

- " “applications of $\S 6(\mathrm{~b})$ are at best conclusory,” pp. 323-24 (Kennedy, J., majority).

- " "applications of $\S 6($ b) [in the complaint] are at best conclusory," p. 343 n.5 (Marshall, J., dissenting) (Kennedy, J., ante at 323-24)).

Connecticut v. Doehr, 501 U.S. 1 (1991).

- “complaint may also be conclusory," p. 14 (White, J., majority).

- “conclusory submissions," p. 14 (White, J., majority).

Lehnert v. Ferris Faculty Ass'n, 500 U.S. 507 (1991).

- "conclusory terms," p. 540 (Marshall, J., concurring in part and dissenting in part). 


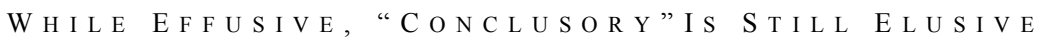

\begin{tabular}{l|ll}
$P$ A G E & 321
\end{tabular}

Siegert v. Gilley, 500 U.S. 226 (1991).

- "specific, nonconclusory factual allegations," p. 236 (Kennedy, J., concurring in judgment).

- "conclusory allegations," p. 236 (Kennedy, J., concurring in judgment).

- "conclusory allegations," p. 246 (Marshall, J., dissenting).

Carnival Cruise Lines, Inc v. Shute, 499 U.S. 585 (1991).

- "conclusory reference," p. 594 (Blackmun, J., majority).

Lujan v. Nat'l Wildlife Fed'n, 497 U.S. 871 (1990).

- "conclusory allegations ... conclusory allegations," p. 888 (Scalia, J., majority).

- “conclusory assertion,” p. 914 (Blackmun, J., dissenting).

Walton v. Arizona, 497 U.S. 639 (1990).

- “conclusory assertion," p. 688 (Blackmun, J., dissenting).

Lewis v. Jeffers, 497 U.S. 764 (1990).

- “conclusory fashion,” p. 797 (Blackmun, J., dissenting).

Maislin Inds., U.S., Inc. v. Primary Steel, Inc., 497 U.S. 116 (1990).

- " conclusory assertion," p. 152 (Stevens, J., dissenting).

Am. Trucking Ass'ns, Inc. v. Smith, 496 U.S. 167 (1990).

- " arbitrary, conclusory, and irreconcilable with the constitutional text," p. 202 (Scalia, J., concurring) (citing Tyler Pipe Indus. v. Washington State Dep't of Revenue, 483 U.S. 232, 260 n.3 (1987) (quoting D. CURRIE, The Constitution in the SuPREMe Court: The First Hundred YEARS 1789-1888, at $234(1985))$ ).

Demosthenes v. Baal, 495 U.S. 731 (1990).

- " "affidavit was not based on a first-hand examination, was conclusory," p. 734 (per curiam).

- " "affidavit is 'conclusory," p. 736 (per curiam) (quoting Order, Baal v. Godinez, No. CV-N.-90-243-HDM (D. Nev., May 31, 1990)).

- $\quad$ "conclusory and equivocal fashion," p. 736 (per curiam).

Clemons v. Mississippi, 494 U.S. 738 (1990).

- "conclusory assertion," p. 765 (Brennan, J., concurring in part and dissenting in part).

U.S. Dep't of Labor v. Triplett, 494 U.S. 715 (1990).

- “conclusory impressions,” p. 726 (Scalia, J., majority).

McKoy v. North Carolina, 494 U.S. 433 (1990).

- "conclusory agreement," p. 450 fn.5 (Blackmun, J., concurring) (quoting United States v. Ferris, 719 F.2d 1405, 1407 (9th Cir. 1983)). 
U N I V E R S I T Y O F P I T T S B U R G H L A W R E V I E W

PAGE

Sable Commc'ns of Cal., Inc. v. FCC, 492 U.S. 115 (1989).

- " conclusory statements," p. 129 (White, J., majority).

Indep. Fed'n of Flight Attendants v. Zipes, 491 U.S. 754 (1989).

- “conclusory dicta," p. 777 n.6 (Marshall, J., dissenting).

Miss. Band of Choctaw Indians v. Holyfield, 490 U.S. 30 (1989).

- " conclusory fashion," p. 40 n.13 (Brennan, J., majority).

- " conclusory statement," p. 53 n.26 (Brennan, J., majority).

Dugger v. Adams, 489 U.S. 401 (1989).

- "conclusory treatment," p. 425 (Blackmun, J., dissenting).

Perry v. Leeke, 488 U.S. 272 (1989).

- “majority's conclusory approach,” p. 287 (Marshall, J., dissenting).

Penson v. Ohio, 488 U.S. 75 (1988).

- “conclusory statement," p. 77 (Stevens, J., majority) (quoting Brief for Petitioner in Anders v. California, O. T. 1966, No. 98, p. 2).

- “conclusory statement," p. 78 (Stevens, J., majority) (quoting Brief for Petitioner in Anders v. California, O. T. 1966, No. 98, p. 2).

United States v. Kozminski, 487 U.S. 931 (1988).

- " "mode of analysis is, of course, conclusory," p. 963 n.12 (Brennan, J., concurring).

Pinter v. Dahl, 486 U.S. 622 (1988).

- "conclusory fashion," p. 641 n.15 (Blackmun, J., majority).

Sun Oil Co. v. Wortman, 486 U.S. 717 (1988).

- "tradition is as troublesome as it is conclusory," p. 739 (Brennan, J., concurring in part and concurring in the judgment).

McCoy v. Wis. Ct. App., Dist. 1, 486 U.S. 429 (1988).

- "conclusory statement," p. 439 n.11 (Stevens, J., majority) (quoting Brief for Petitioner in Anders v. California, O. T. 1966, No. 98, p. 2).

- "conclusory statement," p. 439 n.11 (Stevens, J., majority) (quoting Brief for Petitioner in Anders v. California, O. T. 1966, No. 98, p. 2).

- $\quad$ "conclusory statement," p. 443 (Stevens, J., majority).

Bankers Life \& Cas. Co. v. Crenshaw, 486 U.S. 71 (1988).

- "conclusory assertion," p. 93 (Blackmun, J., concurring in part and dissenting in part).

Brown v. Dodd, 484 U.S. 874 (1987).

- “conclusory order,” p. 874 (Marshall, J., dissenting). 
While EFfuSiVE, “CONCLUSORY”IS STILL E L USIVE

\begin{tabular}{l|ll}
$P$ A G E & $\mathbf{3} 23$
\end{tabular}

Tyler Pipe Indus. v. Wash. Dep't of Revenue, 483 U.S. 232 (1987).

- "may appear arbitrary, conclusory," p. 260 n.3 (Scalia, J., concurring in part and dissenting in part) (quoting D. CURRIE, THE CONSTITUTION IN THE Supreme COURT: THE FIRST HundRed Years 1789-1888, at 234 (1985)).

McCleskey v. Kemp, 481 U.S. 279 (1987).

- “conclusory statement," p. 364 (Blackmun, J., dissenting).

Commodity Futures Trading Comm'n v. Schor, 478 U.S. 833 (1986).

- “conclusory reference," p. 847 (O’Connor, J., majority).

Sheet Metal Workers' Int'l Ass'n Local 28 v. Equal Eemp't Opportunity Comm'n, 478 U.S. 421 (1986).

- " "plurality's conclusory assertion,” p. 497 (O’Connor, J., concurring in part and dissenting in part).

Papasan v. Allain, 478 U.S. 265 (1986).

- "conclusory allegations," p. 299 (Powell, J., concurring in part and dissenting in part).

Press-Enter. Co. v. Cal. Super. Ct. for Riverside County, 478 U.S. 1 (1986)

- "conclusory assertion," p. 15 (Burger, J., majority).

Celotex Corp. v. Catrett, 477 U.S. 317 (1986).

- “conclusory assertion,” p. 328 (White, J., concurring).

- "conclusory assertion," p. 332 (Brennan, J., dissenting).

Int'l Longshoremen's Ass'n v. Davis, 476 U.S. 380 (1986).

- “conclusory assertion,” p. 394 (White, J., majority).

- "conclusory claim," p. 396 (White, J., majority).

- “conclusory assertion,” p. 398 (White, J., majority).

California v. Ciraolo, 476 U.S. 207 (1986).

- "conclusory rejection," p. 219 (Powell, J., dissenting).

New York v. P.J. Video, Inc., 475 U.S. 868 (1986).

- "conclusory allegations," p. 873 (Rehnquist, J., majority).

- "nonconclusory affidavits," p. 877 (Rehnquist, J., majority).

City of Renton v. Playtime Theatres, Inc., 475 U.S. 41 (1986).

- " "justifications for the ordinance were "conclusory,"” p. 50 (Rehnquist, J., majority) (quoting Playtime Theaters v. Renton, 748 F.2d 527, 537 (9th Cir. 1984)).

- “certain conclusory “findings,"” p. 59 (Brennan, J., dissenting).

Messer v. Kemp, 474 U.S. 1088 (1986).

- “conclusory statement," p. 1090 (Marshall, J., dissenting). 
U N I V E R S I T Y O F P I T T S B U R G H L A W R E V I E W

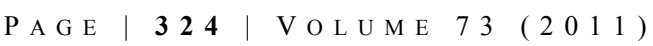

Or. Dep't of Fish and Wildlife v. Klamath Indian Tribe, 473 U.S. 753 (1985).

- “conclusory historical inquiry," p. 787 (Marshall, J., dissenting).

Marek v. Chesny, 473 U.S. 1 (1985).

- "conclusory statement," p. 18 (Brennan, J., dissenting).

Maryland v. Macon, 472 U.S. 463 (1985).

- “conclusory assertion," p. 468 (O'Connor, J., majority) (citing Marcus v. Search Warrant, 367 U.S. 717 (1961)).

Park Ave. Inv. \& Dev., Inc. v. Barkheimer, 471 U.S. 1108 (1985).

- "conclusory assertion," p. 1109 (Burger, J., dissenting).

Anderson v. City of Bessemer City, N.C., 470 U.S. 564 (1985).

- " conclusory statements," p. 572 (White, J., majority).

- " conclusory fashion," p. 581 (Powell, J., concurring).

Wayte v. United States, 470 U.S. 598 (1985).

- “conclusory statements," p. 625 (Marshall, J., dissenting).

Herb's Welding, Inc. v. Gray, 470 U.S. 414 (1985).

- " "term is quite conclusory," p. 432 (Marshall, J., dissenting).

- “ “maritime commerce' is similarly conclusory,” p. 441 n.13 (Marshall, J., dissenting) (quoting White, J., ante at 419).

Sup. Ct. N. H. v. Piper, 470 U.S. 274 (1985).

- "Conclusory second-guessing,” p. 294 (Rehnquist, J., dissenting).

United States v. Young, 470 U.S. 1 (1985).

- "conclusory finding," p. 30 (Brennan, J., concurring in part, dissenting in part).

New Jersey v. T.L.O., 469 U.S. 325 (1985).

- "Court's conclusory analysis," p. 358 (Brennan, J., concurring in part and dissenting in part).

- "conclusory recitation," p. 370 (Brennan, J., concurring in part and dissenting in part).

Seattle Times Co. v. Rhinehart, 467 U.S. 20 (1984).

- "order were too conclusory," p. 25 (Powell, J., majority).

Hoover v. Ronwin, 466 U.S. 558 (1984).

- “conclusory averments," p. 566 n.13 (Powell, J.).

Ellis v. Bhd. of Ry., Airline \& S.S. Clerks, Freight Handlers, Exp. \& Station Emps., 466 U.S. 435 (1984).

- "conclusory disposition," p. 461 (Powell, J., concurring in part and dissenting in part). 


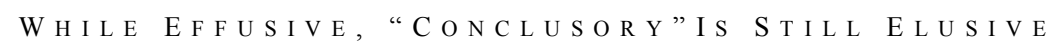

Baldwin Cnty. Welcome Ctr. v. Brown, 466 U.S. 147 (1984).

- “conclusory statements," p. 168 (Stevens, J., dissenting).

Blum v. Stenson, 465 U.S. 886 (1984).

- “conclusory fashion,” p. 898 (Powell, J., majority).

- “conclusory reasons," p. 898 (Powell, J., majority).

Texas v. Mead, 465 U.S. 1041 (1984).

- " conclusory terms," p. 1045 n.4 (Rehnquist, J., dissenting).

Barefoot v. Estelle, 463 U.S. 880 (1983).

- “conclusory paragraph,” p. 914 (Marshall, J., dissenting).

Barclay v. Florida, 463 U.S. 939 (1983).

- “conclusory fashion,” p. 983 (Marshall, J., dissenting).

Planned Parenthood Ass'n of Kan. City, Mo., Inc. v. Ashcroft, 462 U.S. 476 (1983).

- "conclusory language," p. 485 n.7 (Powell, J., majority).

- " conclusory opinion,” p. 485 n.7 (Powell, J., majority).

Simopoulos v. Virginia, 462 U.S. 506 (1983).

- "conclusory terms," p. 518 n.10 (Powell, J., majority).

Illinois v. Gates, 462 U.S. 213 (1983).

- " "wholly conclusory statement," p. 239 (Rehnquist, J., majority).

- "mere conclusory statement," p. 239 (Rehnquist, J., majority).

- " "If the conclusory allegations," p. 277 (Brennan, J., dissenting).

- "surely the conclusory allegations," p. 277 (Brennan, J., dissenting).

- "unwilling to accept conclusory allegations," p. 284 (Brennan, J., dissenting).

- " "accepting conclusory allegations," p. 284 (Brennan, J., dissenting).

- "If the conclusory allegations," p. 287 (Brennan, J., dissenting).

- " "why the conclusory allegations," p. 287 (Brennan, J., dissenting).

- " "purely conclusory,” p. 288 (Brennan, J., dissenting) (quoting United States v. Ventresca, 380 U.S. 102, 108 (1965)).

Hensley v. Eckerhart, 461 U.S. 424 (1983).

- “conclusory statement," p. 440 n.15 (Powell, J., majority).

White v. Estelle, 459 U.S. 1118 (1983).

- "conclusory language," p. 1123 n.4 (Marshall, J., dissenting).

Griggs v. Provident Consumer Disc. Co., 459 U.S. 56 (1982).

- “conclusory footnote," p. 62 (Marshall, J., dissenting).

Washington v. Seattle Sch. Dist. No. 1, 458 U.S. 457 (1982).

- "conclusory statement," p. 475 n.17 (Blackmun, J., majority). 
U N I V E R S I T Y O F P I T T S B U R G H L A W R E V I E W

PAGE

Crawford v. Bd. of Educ. of L.A., 458 U.S. 527 (1982).

- "self-serving conclusory statement," p. 559 n.6 (Marshall, J., dissenting).

- “conclusory statements," p. 562 (Marshall, J., dissenting).

Williams v. United States, 458 U.S. 279 (1982).

- " conclusory description," p. 296 (Marshall, J., dissenting).

Lugar v. Edmondson Oil Co., 457 U.S. 922 (1982).

- "conclusory allegations," p. 943 n.* (Burger, J., dissenting) (quoting United States v. Stanley, 109 U.S. 3, 19 (1883)).

Blue Shield of Va. v. McCready, 457 U.S. 465 (1982).

- " conclusory terms," p. 491 (Rehnquist, J., dissenting).

Patsy v. Bd. of Regents of Fla., 457 U.S. 496 (1982).

- " conclusory note," p. 524 (Powell, J., dissenting).

- "conclusory fashion," p. 533 (Powell, J., dissenting).

Jewett v. Comm'r, 455 U.S. 305 (1982).

- “conclusory statement,” p. 325 (Blackmun, J., dissenting).

Charles D. Bonanno Linen Svc., Inc. v. NLRB, 454 U.S. 404 (1982).

- " conclusory statements," p. 423 (Burger, J., dissenting).

- “conclusory statements," pp. 427-28 (O’Connor, J., dissenting).

*Yazoo Cty. Indus. Dev. Corp. v. Suthoff, 454 U.S. 1157 (1982).

- "conclusory allegations" p. 1158 (Rehnquist, J., dissenting) (quoting the District Judge).

- "whether 'conclusory allegations," pp. 1158-59 (Rehnquist, J., dissenting) (quoting the District Judge).

Metromedia Inc. v. City of San Diego, 453 U.S. 490 (1981).

- "sweeping, conclusory, and rather vague," p. 563 n.5 (Burger, J., dissenting).

Gulf Oil Co. v. Bernard, 452 U.S. 89 (1981).

- " conclusory statements," p. 102 n.16 (Powell, J., majority) (quoting 8 C. Wright \& A. Miller, Federal Practice and Procedure $\S 2035$, p. $265(1970))$.

Minnick v. Cal. Dep't of Corr., 452 U.S. 105 (1981).

- " conclusory allegations," p. 120 n.28 (Stevens, J., majority).

J. Truett Payne Co. Inc. v. Chrysler Motor Corp., 451 U.S. 557 (1981).

- " "[conclusory] statements," p. 560 (Rehnquist, J., majority) (quoting the Fifth Circuit).

- “president's conclusory testimony," p. 270 (Powell, J., dissenting). 
Wh i L E E F U S I E , “C O N C L U S O R Y " I S S T I L L E L U S I V E

\begin{tabular}{l|ll} 
P A G E & 327
\end{tabular}

City of Memphis v. Greene, 451 U.S. 100 (1981).

- " conclusory testimony," p. 146 (Marshall, J., dissenting).

INS v. Jong Ha Wang, 450 U.S. 139 (1981).

- "the allegations of hardship were in the main conclusory and unsupported by affidavit," p. 143 (per curiam).

Sumner v. Mata, 449 U.S. 539 (1981).

- “conclusory statement," p. 555 n.2 (Brennan, J., dissenting).

United States v. Raddatz, 447 U.S. 667 (1980).

- “conclusory approach," p. 700 (Marshall, J., dissenting).

Diamond v. Chakrabarty, 447 U.S. 303 (1980).

- “conclusory statement,” p. 312 (Burger, J., majority).

Godfrey v. Georgia, 446 U.S. 420 (1980).

- "conclusory statement," p. 440 (Marshall, J., concurring in the judgment).

Navarro Sav. Ass'n v. Lee, 446 U.S. 458 (1980).

- “conclusory opinion,” p. 466 (Blackmun, J., dissenting).

NLRB v. Yeshiva Univ., 444 U.S. 672 (1980).

- “conclusory rationales," p. 691 (Powell, J., majority).

McLain v. Real Estate Bd. of New Orleans, Inc., 444 U.S. 232 (1980).

- "conclusory assertion," p. 237 (Burger, J., majority).

Lo-Ji Sales Inc. v. New York, 442 U.S. 319 (1979).

- " conclusory statement," p. 325 (Burger, J., majority).

Cannon v. Univ. of Chicago, 441 U.S. 677 (1979).

- "conclusory, and in my view incorrect, statements," p. 739 n.11 (Powell, J., dissenting).

Gladstone Realtors v. Village of Bellwood, 441 U.S. 91 (1979).

- “complaints are more conclusory," p. 110 (Powell, J., majority).

Vance v. Bradley, 440 U.S. 93 (1979).

- “conclusory fashion," p. 100 (White, J., majority).

Montana v. United States, 440 U.S. 147 (1979).

- " criticized as conclusory," p. 155 n.5 (Marshall, J., majority).

Illinois State Bd. of Elections v. Socialist Workers Party, 440 U.S. 173 (1979).

- “conclusory assertions," p. 187 (Marshall, J., majority).

Colautti v. Franklin, 439 U.S. 379 (1979).

- “conclusory opinion," p. 405 (White, J., dissenting). 
U N I V E R S I T Y O F P I T T S B U R G H L A W R E V I E W

PAGE

Michigan v. Doran, 439 U.S. 282 (1978).

- " conclusory language," p. 286 (Burger, J., majority).

- " conclusory language," p. 290 (Burger, J., majority).

- " "phraseology is conclusory," p. 297 (Blackmun, J., concurring in the result).

N.Y. Times Co. v. Jascalevich, 439 U.S. 1331 (1978).

- "Conclusory assertions,” p. 1335 (Marshall, J., majority).

Houchuns v. KQED, Inc., 438 U.S. 1 (1978).

- “Court of Appeals' conclusory assertion,” p. 14 (Burger, J., majority).

Duke Power Co. v. Carolina Env't Study Grp., Inc., 438 U.S. 59 (1978).

- "conclusory allegations," p. 96 (Rehnquist, J., concurring in the judgment).

Franks v. Delaware, 438 U.S. 154 (1978).

- “conclusory nature," p. 159 n.3 (Blackmun, J., majority).

- " "attack must be more than conclusory," p. 171 (Blackmun, J., majority).

Baldwin v. Fish and Game Comm'n of Montana, 436 U.S. 371 (1978).

- " "effect was conclusory," p. 401 (Brennan, J., dissenting).

Holloway v. Arkansas, 435 U.S. 475 (1978).

- “conclusory representations,” p. 484 n.7 (Burger, J., majority).

Finch v. United States, 433 U.S. 676 (1977).

- "alignment of this case with Wilson rather than with Jenkins was conclusory,” p. 679 (Rehnquist, J., dissenting).

Brenan v. Armstrong, 433 U.S. 672 (1977).

- “conclusory findings," p. 672 (per curiam).

Trans World Airlines, Inc. v. Hardison, 432 U.S. 63 (1977).

- “conclusory assertion,” p. 95 n.8 (Marshall, J., dissenting).

Trainor v. Hernandez, 431 U.S. 434 (1977).

- " conclusory allegations," p. 458 (Brennan, J., dissenting).

- " conclusory allegations," p. 458 (Brennan, J., dissenting).

Smith v. United States, 431 U.S. 291 (1977).

- “conclusory questions," p. 308 (Blackmun, J., majority).

Blackledge v. Allison, 431 U.S. 63 (1977).

- "evidentiary, but NOT conclusory," p. 70 (Steward, J., majority) (quoting Allison).

- "vague [or] conclusory," p. 72 (Steward, J., majority) (quoting Machibroda v. United States, 368 U.S. 487, 495 (1962)). 
Wh i L E EF F U IVE, “C O N C L U S O R Y " I S S T I L L E L U S I V E

- "conclusory allegations," p. 74 (Steward, J., majority).

- "vague [or] conclusory," p. 75 (Steward, J., majority) (quoting Machibroda v. United States, 368 U.S. 487, 495 (1962)).

Wooley v. Maynard, 430 U.S. 705 (1977).

- "merely conclusory words," p. 721 (Rehnquist, J., dissenting).

Freeman v. Zahradnick, 429 U.S. 1111 (1977).

- “conclusory assertion,” p. 1118 (Marshall, J., dissenting).

Brunswick Corp. v. Pueblo Bowl-O-Mat, Inc., 429 U.S. 477 (1977).

- “conclusory testimony," p. 490 (Marshall, J., majority).

Estelle v. Gamble, 429 U.S. 97 (1976).

- "conclusory allegations," p. 114 (Stevens, J., dissenting).

Elrod v. Burns, 427 U.S. 347 (1976).

- " conclusory motions to dismiss," p. 381 n.3 (Powell, J., dissenting).

Hughes v. Alexandria Scrap Corp., 426 U.S. 794 (1976).

- "conclusory assertion," p. 822 (Brennan, J., dissenting).

Serbian E. Orthodox Diocese for U.S. and Canada v. Milivojevich, 426 U.S. 696 (1976).

- “conclusory statement," p. 734 (Rehnquist, J., dissenting).

TSC Indus., Inc. v. Northway, Inc., 426 U.S. 438 (1976).

- “conclusory statements," p. 453 (Marshall, J., majority).

United States v. MacCollum, 426 U.S. 317 (1976).

- "conclusory allegation," p. 326 (Rehnquist, J., majority).

Comm'r v. Shapiro, 424 U.S. 614 (1976).

- " conclusory fashion," 628 (White, J., majority).

- " "wholly conclusory fashion," p. 632 (White, J., majority).

- “conclusory allegation,” p. 632 (White, J., majority).

TIME, Inc. v. Firestone, 424 U.S. 448 (1976).

- “conclusory paragraph,” p. 466 (Powell, J., concurring).

Bynum v. United States, 423 U.S. 952 (1975).

- conclusory statistical summaries," p. 596 (Brennan, J., dissenting).

Warth v. Seldin, 422 U.S. 490 (1975).

- “conclusory terms," p. 503 (Powell, J., majority).

Hicks v. Miranda, 422 U.S. 332 (1975).

- " "findings of the District Court were vague and conclusory," p. 350 (White, J., majority). 
U N I V E R S I T Y O F P I T T S B U R G H L A W R E V I E W

PAGE

United Housing Found., Inc. v. Forman, 421 U.S. 837 (1975).

- " conclusory allegation," p. 860 n.27 (Powell, J., majority).

Ellis v. Dyon, 421 U.S. 426 (1975).

- “conclusory terms," p. 438 n.1 (Powell, J., dissenting).

United States v. Wilson, 420 U.S. 332 (1975).

- " conclusory theories," pp. 343-44 n.11 (Marshall, J., majority).

N. Ga. Finishing, Inc. v. Di-Chem, Inc., 419 U.S. 601 (1975).

- " conclusory allegations," p. 607 (White, J., majority).

- "conclusory allegations," p. 607 (White, J., majority).

- "conclusory affidavit," p. 612 (Powell, J., concurring in the judgment).

Windsor v. United States, 419 U.S. 938 (1974).

- "conclusory finding," p. 942 (Douglass, J., dissenting).

Dorszynski v. United States, 418 U.S. 424 (1974).

- “conclusory finding," p. 452 (Marshall, J., concurring in the judgment).

- "conclusory finding," p. 453 (Marshall, J., concurring in the judgment).

- "conclusory statement," p. 460 (Marshall, J., concurring in the judgment).

Calero-Toledo v. Pearson Yacht Leasing Co., 416 U.S. 663 (1974).

- “conclusory application,” pp. 679-80 n.14 (Brennan, J., majority).

Mitchell v. W.T. Grant Co., 416 U.S. 600 (1974).

- "conclusory allegation," p. 605 (White, J., majority).

Arnett v. Kennedy, 416 U.S. 134 (1974).

- "conclusory affidavits," p. 137 n.1 (Rehnquist, J., majority).

United States v. Gen. Dynamics Corp., 415 U.S. 486 (1974).

- "conclusory statement," p. 526 (Douglass, J., dissenting).

Lewis v. City of New Orleans, 415 U.S. 130 (1974).

- “conclusory language," p. 134 (Powell, J., concurring).

O'Shea v. Littleton, 414 U.S. 488 (1974).

- " conclusory allegations," p. 496 (White, J., majority).

Thompson v. Mississippi, 414 U.S. 890 (1973).

- “conclusory statement," p. 892 (Douglass, J., dissenting).

Heller v. New York, 413 U.S. 483 (1973).

- " conclusory assertions," pp. 488-89 n.4 (Burger, J., majority).

Roaden v. Kentucky, 413 U.S. 496 (1973).

- “conclusory opinion,” p. 502 (Burger, J., majority). 
Wh i L E E F U S I VE, “C O N C L U S O R Y " I S S T I L L E L U S I V E

- “conclusory assertions," p. 502 (Burger, J., majority).

- “conclusory fashion," p. 503 (Burger, J., majority).

- “conclusory assertions," p. 503 (Burger, J., majority).

- "conclusory allegations," p. 506 (Burger, J., majority).

Broadrick v. Oklahoma, 413 U.S. 601 (1973).

- " conclusory assertion," p. 631 (Brennan, J., dissenting).

Summers v. Cenarrusa, 413 U.S. 906 (1973).

- “conclusory manner," p. 907 (White, J., dissenting).

Moor v. Alameda Cty., 411 U.S. 693 (1973).

- " conclusory order," p. 721 n.54 (Marshall, J., majority).

Neely v. Pennsylvania, 411 U.S. 954 (1972).

- "conclusory allegation," p. 959 (Douglass, J., dissenting).

Furman v. Georgia, 408 U.S. 238 (1972).

- “conclusory statement," p. 389 n.12 (Burger, J., dissenting).

M/S Bremen v. Zapata Off-Shore Co., 407 U.S. 1 (1972).

- " conclusory finding," p. 18 (Burger, J., majority).

Adams v. Williams, 407 U.S. 143 (1972).

- "conclusory allegations," p. 157 (Marshall, J., dissenting).

- “conclusory hearsay," p. 159 (Marshall, J., dissenting).

Fuentes v. Shevin, 407 U.S. 67 (1972).

- “conclusory fashion,” p. 74 (Stewart, J., majority).

- “conclusory application,” p. 93 n.30 (Stewart, J., majority).

Williamson v. United States, 405 U.S. 1026 (1972).

- " conclusory proposition,” p. 1029 (Douglass, J., dissenting).

Joseph v. United States, 405 U.S. 1006 (1972).

- " “Army's conclusory remark," p. 1011 n.2 (Douglass, J., dissenting).

Chapman v. California, 405 U.S. 1020 (1972).

- "conclusory affidavit," p. 1020 (Douglass, J., dissenting).

Lindsey v. Normet, 405 U.S. 56 (1972).

- $\quad$ “conclusory argument," p. 64 n.8 (White, J., majority).

Chambers v. Mississippi, 405 U.S. 1205 (1972).

- “conclusory terms," p. 1206 (Powell, J., majority).

NLRB v. Nash-Finch Co., 404 U.S. 138 (1971).

- "conclusory allegation," p. 154 (White, J., dissenting). 
U N I V E R S I T Y O F P I T T S B U R G H L A W R E V I E W

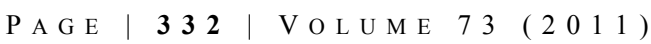

Richardson v. Belcher, 404 U.S. 78 (1971).

- " conclusory treatment," p. 92 (Marshall, J., dissenting).

United States v. Harris, 403 U.S. 573 (1971).

- “conclusory statement," p. 598 (Harlan, J., dissenting).

McKeiver v. Pennsylvania, 403 U.S. 528 (1971).

- "conclusory language of an indictment," p. 542 (Blackmun, J., majority).

Coolidge v. New Hampshire, 403 U.S. 443 (1971).

- "issuance of the warrant were so conclusory," p. 449 (Stewart, J., majority).

Palmer v. Thompson, 403 U.S. 217 (1971).

- “conclusory statement," p. 273 (Marshall, J., dissenting).

Whitcomb v. Chavis, 403 U.S. 124 (1971).

- “conclusory terms," p. 167 (Harlan, J., separate opinion).

Perez v. Campbell, 402 U.S. 637 (1971).

- “conclusory terms," p. 668 (Blackmun, J., dissenting).

Richardson v. Perales, 402 U.S. 389 (1971).

- “conclusory nature of the reports," p. 395 (Blackmun, J., majority).

New Haven Inclusion Cases, 399 U.S. 392 (1970).

- " "argument to the contrary is completely conclusory," p. 503 (Black, J., dissenting).

United States v. Sisson, 399 U.S. 267 (1970).

- $\quad$ “conclusory terms," pp. 279-80 n.7 (Harlan, J., majority).

Norton v. Discipline Comm. of E. Tenn. State Univ., 399 U.S. 906 (1970).

- "conclusory testimony," p. 907 (Marshall, J., dissenting).

Welsh v. United States, 398 U.S. 333 (1970).

- cconclusory assertion," p. 359 (Harlan, J., concurring in the result).

McMann v. Richardson, 397 U.S. 223 (1970).

- "conclusory fashion," p. 763 (White, J., majority).

- "conclusory allegations," p. 765.

- "vague, conclusory, or palpably incredible," p. 787 (Brennan, J., dissenting) (quoting Machibroda v. United States, 368 U.S. 487, 495 (1962)).

*Taggart v. Weinacker's Inc., 397 U.S. 223 (1970).

- "conclusory affidavits," p. 225 (per curiam) (quoting Petitioner's complaints). 
While EFFUSiVE, “CONCLUSORY”IS STILL E LUSIVE

\begin{tabular}{l|l}
$P$ A G E & $\mathbf{3 3} 3$
\end{tabular}

Chimel v. California, 395 U.S. 752 (1969).

- “conclusory terms," p. 754 (Stewart, J., majority).

Black Unity League of Ky. v. Miller, 394 U.S. 100 (1969).

- "allegations of harassment were entirely conclusory," p. 100 (per curiam).

- "conclusory allegations," p. 101 (per curiam).

Spinelli v. United States, 393 U.S. 410 (1969).

- “conclusory report," p. 438 (Fortas, J., dissenting).

Lee Art Theatre, Inc. v. Virginia, 392 U.S. 636 (1968).

- "conclusory assertions," p. 637 (per curiam).

- " csolely upon the conclusory assertions," p. 637 (per curiam).

Hanover Shoe Inc. v. United Shoe Machinery Corp., 392 U.S. 481 (1968).

- “conclusory nature," pp. 498-99 n.13 (White, J., majority).

Sibron v. New York, 392 U.S. 40 (1968).

- " conclusory statement," p. 76 (Harlan, J., concurring in the result).

Protective Comm. for Indep. Stockholders of TMT Trailer Ferry, Inc. v. Anderson, 390 U.S. 414 (1968).

- " "conclusory recommendation," p. 434 (White, J., majority).

- "conclusory denials of liability," p. 436 (White, J., majority).

- “conclusory statements," p. 436 (White, J., majority).

Provident Tradesmens Bank \& Trust Co. v. Patterson, 390 U.S. 102, (1968).

- " conclusory sense," pp. 118-19 n.15 (Harlan, J., dissenting).

W.E.B. DuBois Clubs of Am. v. Clark, 389 U.S. 309 (1967).

- “conclusory allegations," p. 313 (per curiam).

Berger v. N.Y., 388 U.S. 41 (1967).

- “conclusory assertions," p. 101 (Harlan, J., dissenting).

- “conclusory allegations," p. 104 (Harlan, J., dissenting).

- "conclusory assertion,” p. 104 n.7 (Harlan, J., dissenting).

Afroyim v. Rusk, 387 U.S. 253 (1967).

- "conclusory and quite unsubstantiated assertion," p. 269 (Harlan, J., dissenting).

United States v. Gen. Motors Corp., 384 U.S. 127 (1966).

- “conclusory 'findings,"” pp. 141-42 n.16 (Fortas, J., majority).

- “trial court's conclusory 'finding,"” p. 142 (Fortas, J., majority).

Perry v. Commerce Loan Co., 383 U.S. 292 (1966).

- “citation of $\S 602$ is conclusory," p. 408 (Harlan, J., dissenting). 
U N I V E R S I T Y O F P I T T S B U R G H L A W R E V I E W

PAGE

United Gas Imp. Co. v. Callery Props., Inc., 382 U.S. 223 (1965).

- "conclusory sentence," p. 233 (Harlan, J., concurring in part and dissenting in part).

Armstrong v. Manzo, 380 U.S. 545 (1965).

- “conclusory terms," p. 547 (Stewart, J., majority).

United States v. Ventresca, 380 U.S. 102 (1965).

- "affidavits which are purely conclusory," p. 108 (Goldberg, J., majority).

Beck v. Ohio, 379 U.S. 89 (1964).

- “conclusory statement," p. 92 (Stewart, J., majority).

Schlagenhauf v. Holder, 379 U.S. 104 (1964).

- " conclusory allegations," p. 118 (Goldberg, J., majority).

- " conclusory statement," p. 120 (Goldberg, J., majority).

- "charges are conclusory,"” p. 124 (Black, J., concurring in part and dissenting in part) (quoting the majority opinion).

- "pleadings being 'conclusory,"” p. 124 (Black, J., concurring in part and dissenting in part) (quoting the majority opinion).

Rabinowitz v. Kennedy, 376 U.S. 605 (1964).

- " conclusory language," p. 610 (Goldberg, J., majority).

United States v. Merz, 376 U.S. 192 (1964).

- "Conclusory findings," p. 198 (Douglass, J., majority).

- “conclusory findings," p. 198 (Douglass, J., majority).

Hardy v. United States, 375 U.S. 277 (1964).

- $\quad$ "to the conclusory allegations," p. 278 (Douglass, J., majority) (quoting Ingram v. United States, 315 F.2d 29, 30-31 (1962)) (internal quotations omitted).

- "conclusory in nature," p. 280 n.2 (Douglass, J., majority) (quoting Ingram v. United States, 315 F.2d 29, 30-31 (1962)).

- "conclusory allegations," p. 280 n.2 (Douglass, J., majority) (quoting Ingram v. United States, 315 F.2d 29, 30-31 (1962)).

- $\quad$ "relates to the conclusory allegations," p. 285 (Goldberg, J., concurring) (quoting Ingram v. United States, 315 F.2d 29, 30-31 (1962)) (internal quotations omitted).

Sch. Dist. of Abington Tp., Pa. v. Schempp, 374 U.S. 203 (1963).

- "conclusory language," p. 319 (Stewart, J., dissenting).

- “conclusory allegations," p. 319 (Stewart, J., dissenting). 


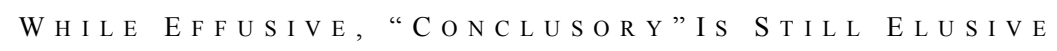

\begin{tabular}{l|l}
$P$ A G E & $\mathbf{3 3 5}$
\end{tabular}

Sanders v. United States, 373 U.S. 1, (1963).

- "conclusory, or palpably incredible," p. 21 (Brennan, J., majority) (quoting Machibroda v. United States, 368 U.S. 487, 495-96 (1962)).

Draper v. Washington, 372 U.S. 487 (1963).

- " "almost wholly conclusory,” p. 493 (Goldberg, J., majority).

- “conclusory statements,” p. 493 (Goldberg, J., majority).

Baker v. Carr, 369 U.S 186 (1962).

- "conclusory allegations" p. 251 (Clark, J., concurring).

Machibroda v. United States, 368 U.S. 487 (1962).

- " conclusory, or palpably incredible his allegations," p. 495 (Stewart, J., majority).

- "allegations are sufficiently 'vague, conclusory, or palpably incredible,"” p. 501 (Clark, J., dissenting) (quoting the majority opinion).

Marcus v. Search Warrants of Prop. at 104 E. Tenth St. Kansas City, Mo., 367 U.S. $717(1961)$

- “conclusory assertions," p. 732 (Brennan, J., majority).

Reck v. Pate, 367 U.S. 433 (1961).

- "conclusory findings," p. 452 (Clark, J., dissenting).

Wilkinson v. United States, 365 U.S. 399 (1961).

- " conclusory statement," p. 418 (Black, J., dissenting).

Braden v. United States, 365 U.S. 431 (1961).

- "conclusory statement," pp. 439-40 n.2 (Black, J., dissenting).

Monroe v. Pape, 365 U.S. 167 (1961).

- " conclusory allegations," p. 240 n.68 (Frankfurter, J., dissenting).

- “conclusory and unspecific claim,” p. 258 (Frankfurter, J., dissenting).

E.R. R. Presidents Conference v. Noerr Motor Freight, Inc., 365 U.S. 127 (1961).

- “conclusory finding," pp. 138-40 fn.18 (Black, J., majority).

Schilling v. Rogers, 363 U.S. 666 (1960).

- "conclusory allegations,” p. 676 (Harlan, J., majority).

Comm'r v. Duberstein, 363 U.S. 278 (1960).

- "findings become so sparse and conclusory," p. 292 (Brennan, J., majority).

- “conclusory, general findings,” p. 292 (Brennan, J., majority).

Mitchell v. H.B. Zachary Co., 362 U.S. 310 (1960).

- “conclusory phrases," p. 320 (Frankfurter, J., majority). 
U N I V E R S I T Y O F P I T T S B U R G H L A W R E V I E W

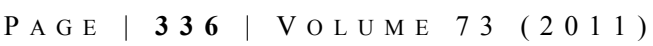

Atlantic Refining Co. v. Public Serv. Comm.'n of N.Y., 360 U.S. 378 (1959).

- " conclusory finding," p. 393 (Clark, J., majority).

FTC v. Standard Oil Co., 355 U.S. 396 (1958).

- “conclusory allegations," p. 407 n.1 (Douglass, J., dissenting).

Konigsberg v. State Bar of Cal., 353 U.S. 252 (1957).

- $\quad$ "underlying his conclusory denial," p. 309 (Harlan, J., dissenting).

Griffin v. Illinois, 351 U.S. 12 (1956).

- “conclusory allegation,” p. 32 (Harlan, J., dissenting).

Williams v. Georgia, 349 U.S. 375 (1955).

- "conclusory pleading," p. 401 (Clark, J., dissenting).

Dalehite v. United States, 346 U.S. 15 (1953).

- "Statements conclusory in nature," p. 24 n.8 (Reed, J., majority).

Zorach v. Clauson, 343 U.S. 306 (1952).

- ““conclusory' allegation,” p. 312 n.7 (Douglass, J., majority) (quoting Zorach v. Clauson, 303 N.Y. 161, 174 (N.Y. 1951)).

- "conclusory in character," p. 322 n.1 (Frankfurter, J., dissenting) (quoting Zorach v. Clauson, 303 N.Y. 161, 174 (N.Y. 1951)).

Schneiderman v. United States, 320 U.S. 118 (1943).

- "conclusory findings," pp. 153-54 n.40 (Murphy, J., majority).

*United States v. Wayne Pump Co., 317 U.S. 200 (1942).

- "conclusory in character," pp. 207-08 n.3 (Reed, J., majority). 


\section{Appendix F}

\section{Correspondence From Merriam-Webster to Donald J. Kochan Regarding Inclusion of Word "Conclusory" in Its Dictionaries, February 8, 2011}

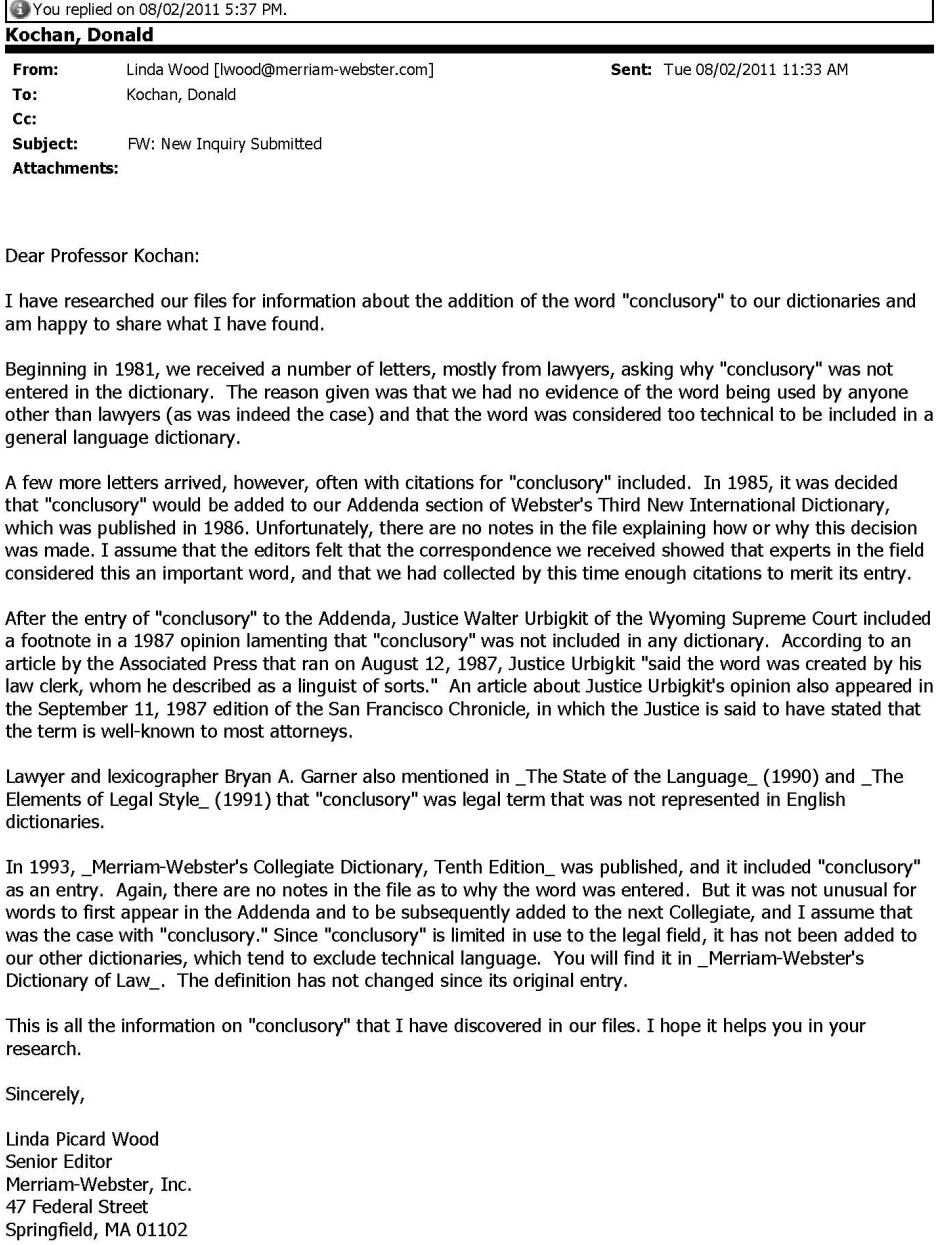

Beginning in 1981, we received a number of letters, mostly from lawyers, asking why "conclusory" was not entered in the dictionary. The reason given was that we had no evidence of the word being used by anyone other than lawyers (as was indeed the case) and that the word was considered too technical to be included in a general language dictionary.

A few more letters arrived, however, often with citations for "conclusory" included. In 1985, it was decided that "conclusory" would be added to our Addenda section of Webster's Third New International Dictionary which was published in 1986. Unfortunately, there are no notes in the file explaining how or why this decision was made. I assume that the editors felt that the correspondence we received showed that experts in the field considered this an important word, and that we had collected by this time enough citations to merit its entry.

After the entry of "conclusory" to the Addenda, Justice Walter Urbigkit of the Wyoming Supreme Court included a footnote in a 1987 opinion lamenting that "conclusory" was not included in any dictionary. According to an article by the Associated Press that ran on August 12, 1987, Justice Urbigkit "said the word was created by his law clerk, whom he described as a lingulst of sorts." An article about Justice Urbigkit's opinion also appeared in the September 11, 1987 edition of the San Francisco Chronicle, in which the Justice is said to have stated that the term is well-known to most attorneys.

Lawyer and lexicographer Bryan A. Garner also mentioned in _The State of the Language_ (1990) and _The Elements of Legal Style_ (1991) that "conclusory" was legal term that was not represented in English dictionaries.

In 1993,_Merriam-Webster's Collegiate Dictionary, Tenth Edition_was published, and it included "conclusory" as an entry. Again, there are no notes in the file as to why the word was entered. But it was not unusual for words to first appear in the Addenda and to be subsequently added to the next Collegiate, and I assume that was the case with "conclusory." Since "conclusory" is limited in use to the legal field, it has not been added to our other dictionaries, which tend to exclude technical language. You will find it in _Merriam-Webster's Dictionary of Law_. The definition has not changed since its original entry.

This is all the information on "conclusory" that I have discovered in our files. I hope it helps you in your research.

Sincerely,

Linda Picard Wood

Senior Editor

Merriam-Webster, Inc

47 Federal Street

Springfield, MA 01102 


\section{Appendix G}

\section{Correspondence From American Heritage Dictionary to Donald J. Kochan Regarding Inclusion of Word "Conclusory" in Its Dictionaries, \\ October 18, 2011}

conclusory in the American Heritage Dictionary

Page 1 of 1

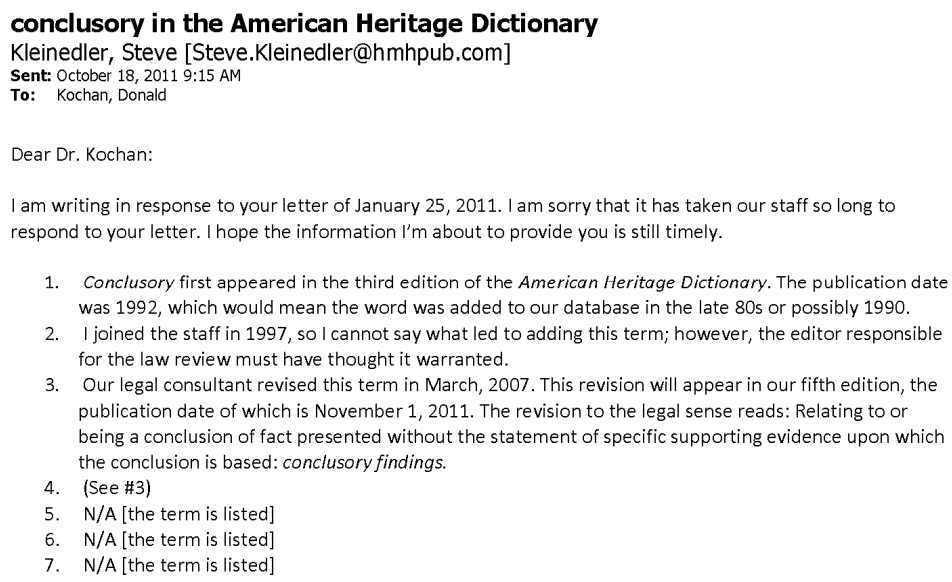

I have no information about the rationale for defining or inclusion in the early 90 s. The consultant had this to say about our former definition

"The existing definition is wrong. The example given with the definition is making the point that naked factual findings, without more, aren't formally adequate for a magistrate's decision (as an appellate court would not be able to determine the basis for the conclusions of the magistrate and so would be dealing with an incomplete record). Calling something conclusory is not to call it wrong, but to call it incomplete or inadequate in format. It has nothing to do with being "convincing" or "not. . . supported by all the facts." A lab technician stating that the defendant was the origin of a blood sample found at the scene of a crime would be presenting conclusory testimony; a lab technician presenting the comparison of the DNA profile of the defendant and that of the sample taken from the scene would be not be presenting conclusory testimony."

And then she provided evidence of its use in legal writings. The previous definition had been: Convincing, but not so much so that contradiction is impossible; not justified or supported by all of the facts: "Perfunctory and conclusory findings of the magistrate ... did not comport with requirements of Federal Rules of Civil Procedure" (National Law Journal).

I am sorry we did not get this information to you sooner, and I hope it is still helpful.

Steve Kleinedler

Executive Editor, American Heritage Dictionary

Houghton Mifflin Harcourt

6173515023 